\title{
\#USGS
}

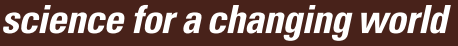

Prepared in cooperation with the Mercer School District

- Water Quality, Hydrology, and Simulated Response to Changes in Phosphorus Loading of Mercer Lake, Iron County, Wisconsin, with Special Emphasis on the Effects of Wastewater Discharges

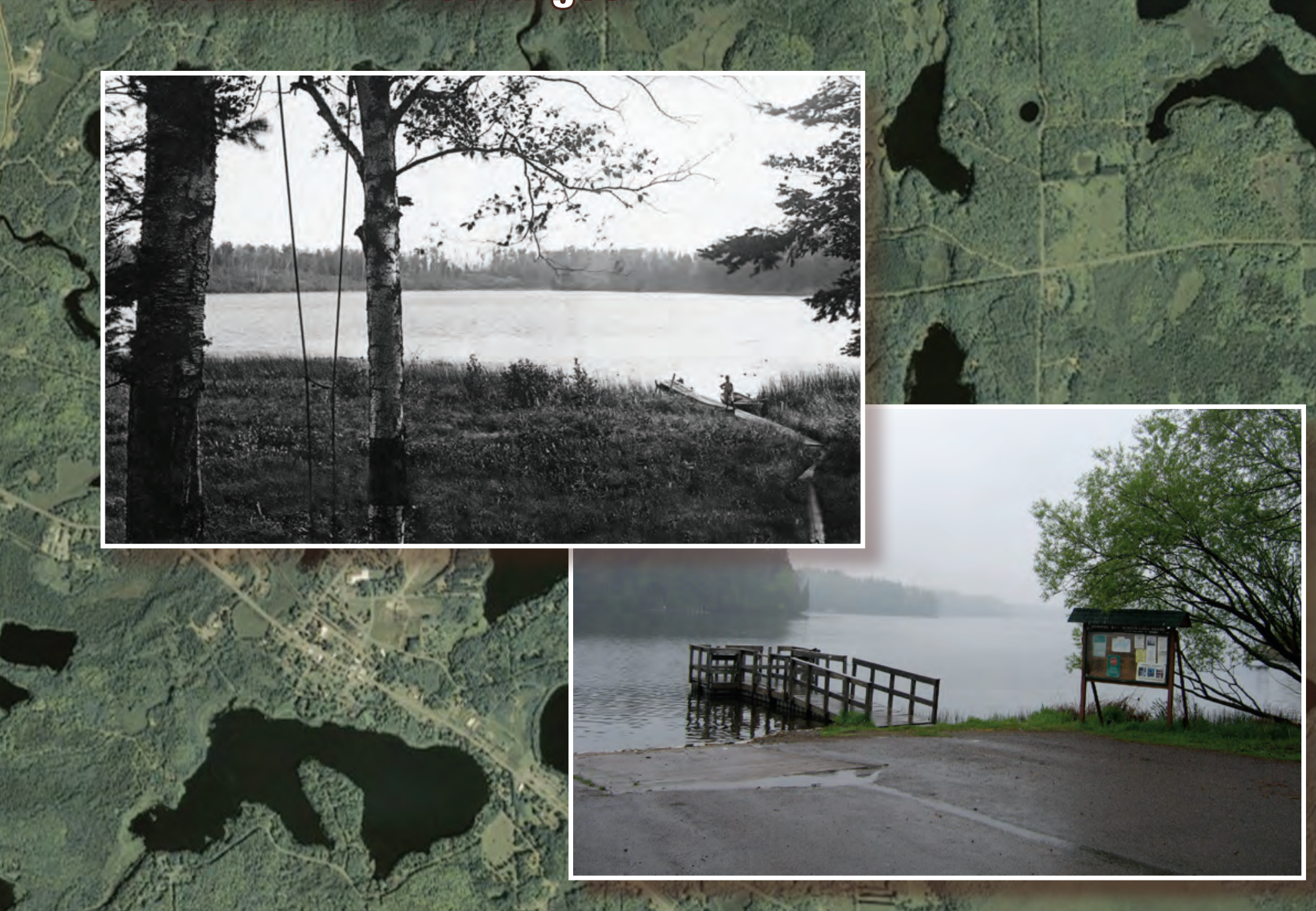

Scientificic lnvestigations Report 2012-5134

U.S. Department of the Interior

U.S. Geological Survey

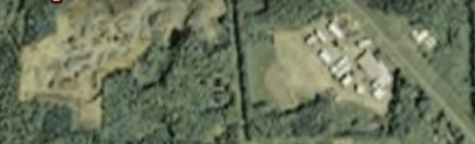


Cover photos. (upper left) historical photo of J.A. Tederstrom boat landing, Mercer Lake, Mercer, Wis., (lower right), public boat landing, Mercer Lake, Mercer, Wis., by Dale Robertson, USGS, (background) 2010 aerial photo of Mercer Lake and its watershed, Iron County, Wis. 


\section{Water Quality, Hydrology, and Simulated Response to Changes in Phosphorus Loading of Mercer Lake, Iron County, Wisconsin, with Special Emphasis on the Effects of Wastewater Discharges}

By Dale M. Robertson, Herbert S. Garn, William J. Rose, Paul F. Juckem, and Paul C. Reneau

Prepared in cooperation with the Mercer School District

Scientific Investigations Report 2012-5134 


\title{
U.S. Department of the Interior \\ KEN SALAZAR, Secretary \\ U.S. Geological Survey \\ Marcia K. McNutt, Director
}

\author{
U.S. Geological Survey, Reston, Virginia: 2012
}

For more information on the USGS - the Federal source for science about the Earth, its natural and living resources, natural hazards, and the environment, visit http://www.usgs.gov or call 1-888-ASK-USGS.

For an overview of USGS information products, including maps, imagery, and publications, visit http://www.usgs.gov/pubprod

To order this and other USGS information products, visit http://store.usgs.gov

Any use of trade, firm, or product names is for descriptive purposes only and does not imply endorsement by the U.S. Government.

Although this information product, for the most part, is in the public domain, it also may contain copyrighted materials as noted in the text. Permission to reproduce copyrighted items must be secured from the copyright owner.

Suggested citation:

Robertson, D.M., Garn, H.S., Rose, W.J., Juckem, P.F., and Reneau, P.C., 2012, Hydrology, water quality, and response to simulated changes in phosphorus loading of Mercer Lake, Iron County, Wisconsin, with emphasis on effects of wastewater discharges on water quality: U.S. Geological Survey Scientific Investigations Report 2012-5134, 58 p 


\section{Contents}

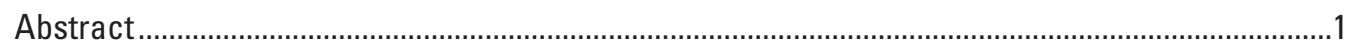

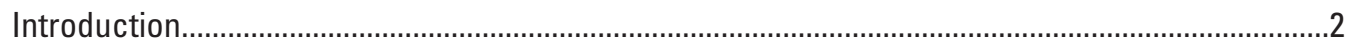

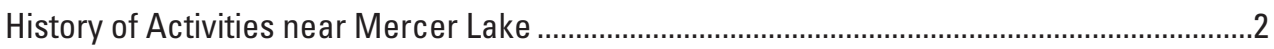

Shallow Lakes and Internal Phosphorus Loading .................................................................

Lake-Sediment Quality .........................................................................................................

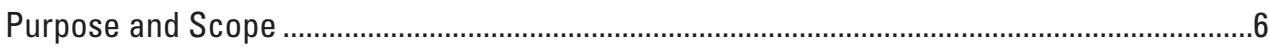

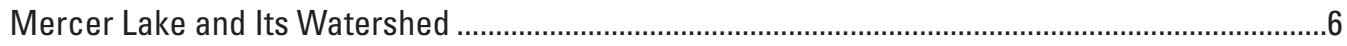

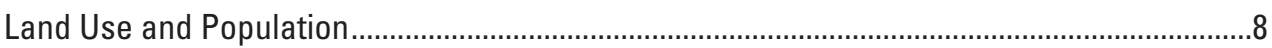

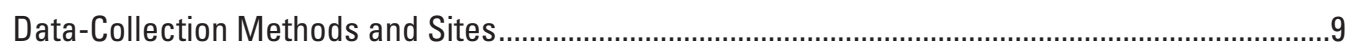

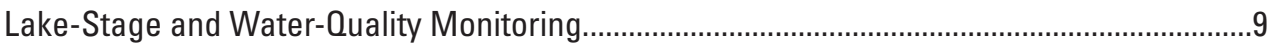

Lake Classification............................................................................................................

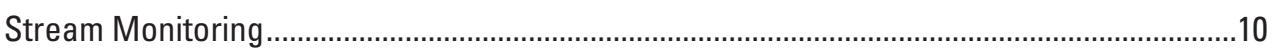

Estimating Input from the Ungaged Near-Lake Drainage Areas ............................................11

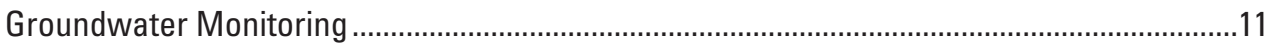

Lake-Sediment Analyses .........................................................................................................

Phosphorus Release Rates from Mercer Lake Sediments ...............................................11

Composition of Mercer Lake Sediments........................................................................13

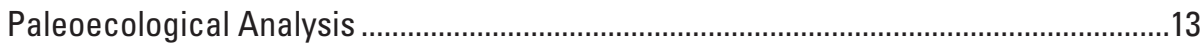

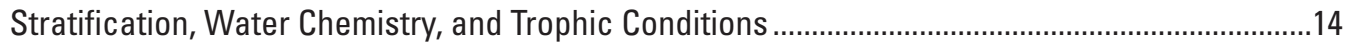

Stratification and Dissolved Oxygen .............................................................................14

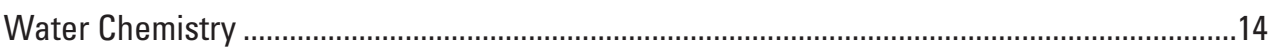

Inferred Lake Water Quality from Analyses of Lake Sediment ...................................................22

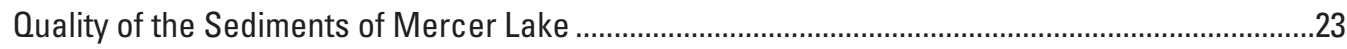

Organic Content, Phosphorus, and Trace Elements ...........................................................23

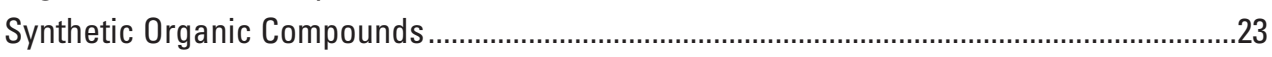

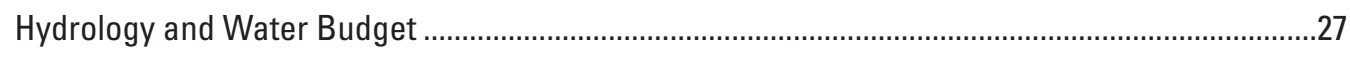

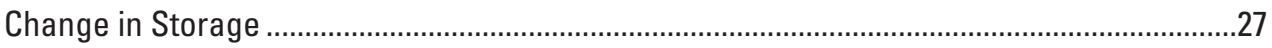

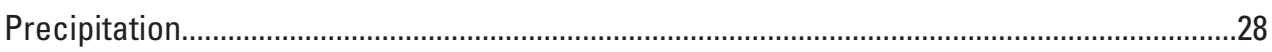

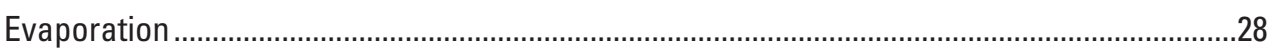

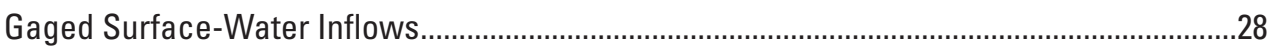

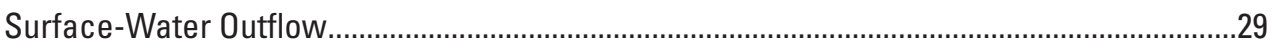

Groundwater Flow near and into Mercer Lake ......................................................................2

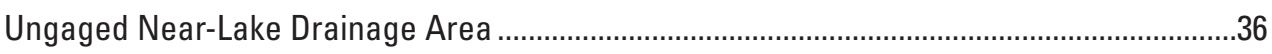

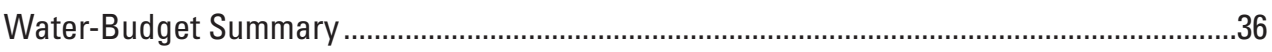

Sources of Phosphorus......................................................................................................

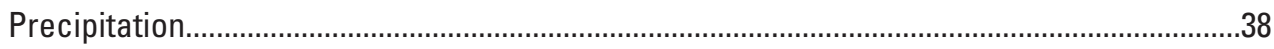

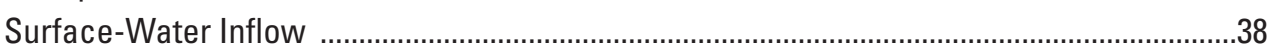

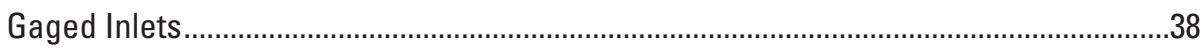

Ungaged Near-Lake Drainage Areas ...........................................................................38

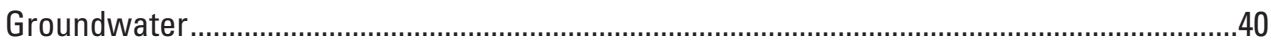

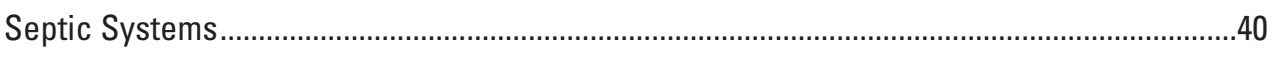

Release of Phosphorus from Lake Sediments ..................................................................42

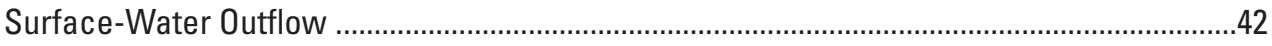




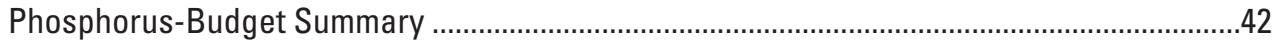

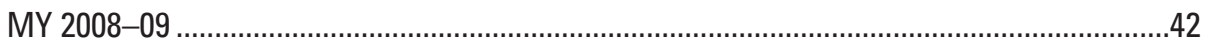

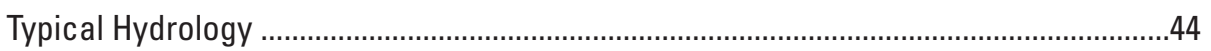

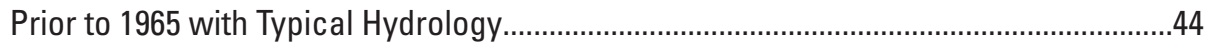

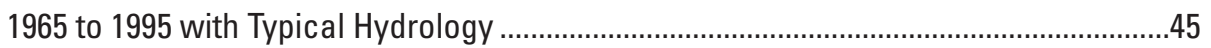

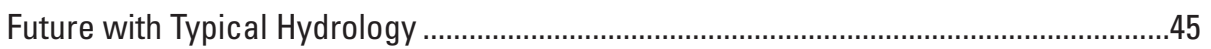

Simulated Changes in Water Quality in Response to Changes in Phosphorus Loading .................46

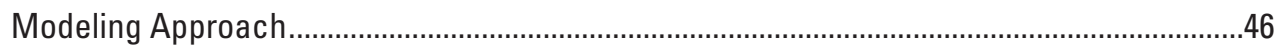

Verification and Adjustments for Model Biases................................................................49

Response in Water Quality to Basinwide Changes in Phosphorus Loading............................49

Response in Water Quality during Typical Hydrologic Conditions ............................................49

Simulated Effects of Internal Phosphorus Loading ...........................................................50

Response in Water Quality to Past and Future Anthropogenic Changes

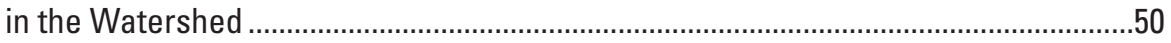

Importance of Internal Phosphorus Loading to Lake Productivity..................................................50

Relative Importance of Natural and Anthropogenic Changes in the Watershed

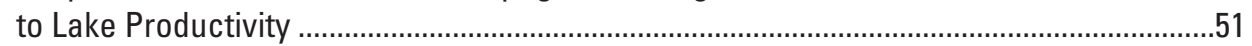

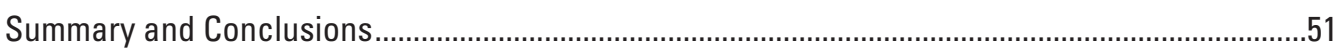

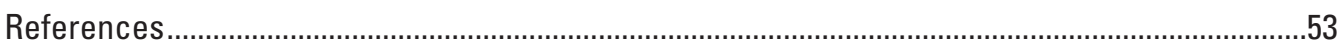

Appendix 1. Wastewater indicators in sediment (Schedule 5433 compounds), analyzed at the U.S. Geological Survey National Water Quality Laboratory in Denver, Colo............57

\section{Figures}

1. 2010 Aerial photo of Mercer Lake with its watershed delineated ...

2. 2010 Aerial photo of Mercer Lake with the near-lake drainage area adjacent to Mercer Lake and surface-water and groundwater data-collection sites identified.

3. Graph of the population of Mercer, Iron County, Wis., 1910-2010 ……...........................9

4. Photographs illustrating sediment-sample collection for $A$, phosphorus release analyses and $B$, composition analyses

5. Continuous data diagrams of temperature and dissolved oxygen distribution during open water periods of monitoring years 2008-09, collected at the Deep Hole site in the East Basin of Mercer Lake..

6. Graph of dissolved oxygen concentrations measured throughout Mercer Lake, on March 26, 2008.

7. Scatter plots of near-surface $A$, total phosphorus concentrations, $B$, chlorophyll a concentrations, and $C$, Secchi depths in the East and West Basins of Mercer Lake during monitoring years 2008-09

8. Graph of near-surface and near-bottom total phosphorus concentrations in the East and West Basins of Mercer Lake during monitoring years 2008-09.

9. Near-surface $A$, total phosphorus concentrations, $B$, chlorophyll a concentrations, and $C$, Secchi depths in the East Basin of Mercer Lake from 1973 to 2011

10. Trophic state index values based on water quality measured in the East Basin of Mercer Lake from 1973 to 2011

11. Graph of estimated changes in water clarity (Secchi depth) inferred from changes in diatom assemblages in the sediment core collected in Mercer Lake. 
12. Bar graph of monthly precipitation at Mercer Lake during monitoring years 2008-09 relative to long-term average precipitation for the period 1971-2000.

13. Graphs of daily discharge, phosphorus concentrations, and phosphorus loads at $A$, Little Turtle Inlet, $B$, storm drain outlet near the boat landing, and $C$, Mercer Lake Outlet, during monitoring years 2008-09

14. Map of hydrologic features simulated with the GFLOW analytic groundwater-flow model near Mercer Lake.

15. Scatter plot of measured and simulated water levels for the GFLOW model of the area near Mercer Lake.

16. Scatter plot of measured and simulated streamflow and groundwater

inflow to Mercer Lake for the GFLOW model of the area near Mercer Lake .34

17. Map of simulated groundwater-flow directions and area contributing groundwater to Mercer Lake..

18. Pie diagrams of water budgets for Mercer Lake for monitoring years 2008-9 and for typical hydrologic conditions.

19. Bar graph of the monthly accuracy of the water budget on the basis of comparisons of total water inputs and outputs plus storage change for Mercer Lake during monitoring years 2008-09

20. Bar graph of concentrations of dissolved phosphorus in groundwater from piezometers near Mercer Lake.

21. Pie diagrams of phosphorus budgets for Mercer Lake for monitoring years 2008-09 and for typical hydrologic conditions.

22. Diagrams of measured and simulated summer-average near-surface concentrations of $A$, total phosphorus, $B$, chlorophyll $a$, and $C$, Secchi depths in Mercer Lake in response to various phosphorus-loading scenarios.

\section{Tables}

1. Chronological history of major activities potentially affecting the water quality of Mercer Lake .4

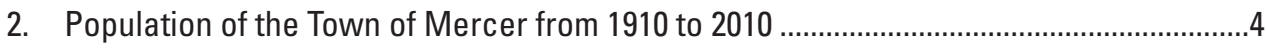

3. Morphometric characteristics of Mercer Lake .................................................................

4. Land use/land cover in the contributing areas to Mercer Lake .........................................8

5. Near-surface, summer-average (May-September) total phosphorus, chlorophyll $a$, and Secchi depths for the East and West Basins, and trophic state index values based on data from the East Basin of Mercer Lake from 1973 to 2011

6. Phosphorus and trace element concentrations in the bottom sediment of Mercer and Grand Portage Lakes.

7. Concentrations of wastewater compounds detected in the bottom sediment of Mercer and Grand Portage Lakes

8. Summary of water-budget components for Mercer Lake during monitoring years 2008-09 and during typical hydrologic conditions

9. Summary of the phosphorus-budget components for Mercer Lake, during monitoring years 2008-09, during typical hydrologic conditions, and with future development in the watershed

10. Phosphorus input from septic systems, sewage treatment plants, and untreated areas into Mercer Lake. 
11. Estimated areas of aerobic and anaerobic sediment below 6.5 feet in Mercer Lake and estimated sediment phosphorus release from May 1 to September 30

12. Summary of estimated rates of phosphorus release from the sediments of Mercer Lake

13. Estimated water quality in Mercer Lake in response to various phosphorus-loading scenarios based on the Canfield and Bachman natural-lake model and Carlson trophic-state-index equations

\section{Conversion Factors}

\begin{tabular}{|c|c|c|}
\hline Multiply & By & To obtain \\
\hline \multicolumn{3}{|c|}{ Length } \\
\hline inch (in) & 25.4 & millimeter (mm) \\
\hline foot $(\mathrm{ft})$ & 0.3048 & meter $(\mathrm{m})$ \\
\hline mile (mi) & 1.609 & kilometer (km) \\
\hline \multicolumn{3}{|c|}{ Area } \\
\hline acre & 0.004047 & square kilometer $\left(\mathrm{km}^{2}\right)$ \\
\hline \multicolumn{3}{|c|}{ Volume } \\
\hline cubic foot $\left(\mathrm{ft}^{3}\right)$ & 0.02832 & cubic meter $\left(\mathrm{m}^{3}\right)$ \\
\hline acre-foot (acre-ft) & 1,233 & cubic meter $\left(\mathrm{m}^{3}\right)$ \\
\hline \multicolumn{3}{|c|}{ Mass } \\
\hline pound, avoirdupois (lb) & 0.4536 & kilogram (kg) \\
\hline \multicolumn{3}{|c|}{ Miscellaneous rates and yields } \\
\hline inch per year (in/yr) & 25.4 & millimeter per year $(\mathrm{mm} / \mathrm{yr})$ \\
\hline foot per day $(\mathrm{ft} / \mathrm{d})$ & 0.3048 & meter per day $(\mathrm{m} / \mathrm{d})$ \\
\hline cubic feet per second $\left(\mathrm{ft}^{3} / \mathrm{s}\right)$ & 0.02832 & cubic meter per second $\left(\mathrm{m}^{3} / \mathrm{s}\right)$ \\
\hline gallons per day (gal/d) & 0.003785 & cubic meters per day $\left(\mathrm{m}^{3} / \mathrm{d}\right)$ \\
\hline gram per square centimeter $\left(\mathrm{g} / \mathrm{cm}^{2}\right)$ & $89,217.0$ & pounds per acre (lb/acre) \\
\hline pound per year $(\mathrm{lb} / \mathrm{yr})$ & 0.4536 & kilogram per year (kg/yr) \\
\hline pound per square foot $\left(\mathrm{lb} / \mathrm{ft}^{2}\right)$ & 4.8824 & kilogram per square meter $\left(\mathrm{kg} / \mathrm{m}^{2}\right)$ \\
\hline pounds per acre (lb/acre) & 112.07 & milligrams per square meter $\left(\mathrm{mg} / \mathrm{m}^{2}\right)$ \\
\hline pounds per square mile $\left(\mathrm{lb} / \mathrm{mi}^{2}\right)$ & 0.1751 & kilograms per square kilometer $\left(\mathrm{kg} / \mathrm{km}^{2}\right)$ \\
\hline
\end{tabular}

Temperature in degrees Celsius $\left({ }^{\circ} \mathrm{C}\right)$ may be converted to degrees Fahrenheit $\left({ }^{\circ} \mathrm{F}\right)$ as follows: ${ }^{\circ} \mathrm{F}=\left(1.8 x^{\circ} \mathrm{C}\right)+32$

Specific conductance is given in microsiemens per centimeter at 25 degrees Celsius $(\mu \mathrm{S} / \mathrm{cm}$ at $\left.25^{\circ} \mathrm{C}\right)$.

Vertical coordinate information is referenced to the National Geodetic Vertical Datum of 1929 (NGVD 29). Sea level refers to 0 feet above the vertical datum.

Concentrations of chemical constituents in water are given either in milligrams per liter (mg/L) or micrograms per liter $(\mu \mathrm{g} / \mathrm{L})$. All dissolved chemical constituents were collected and filtered through a $0.45-\mu \mathrm{m}$ filter. Chlorophyll a samples were filtered through a 5 - $\mu \mathrm{m}$ filter.

Concentrations of chemicals in sediment are given in micrograms per kilogram of sediment ( $\mu \mathrm{g} /$ $\mathrm{kg}$ ) or milligrams per kilogram of sediment $(\mathrm{mg} / \mathrm{kg})$. 


\section{Acknowledgments}

\section{Technical Reviewers}

Richard L. Kiesling, Hydrologist, U.S. Geological Survey, Minnesota Water Science Center, Mounds View, Minn.

Lori M. Fuller, Geographer, U.S. Geological Survey, Michigan Water Science Center, Lansing, Mich.

\section{Local Project Coordinators}

Douglas Chidley, Mercer Lake Association, Mercer, Wis.

James Kreitlow, Water Resources Management Specialist, Wisconsin Department of Natural Resources, Rhinelander, Wis.

\section{Field Support}

Jerry Huffmaster, Mercer Lake Association, Mercer, Wis.

\section{Publishing Support}

Elizabeth A. Ciganovich, Technical Writer-Editor, U.S. Geological Survey Science Publishing Network, Madison, Wis.

Marta Anderson, Visual Information Specialist, U.S. Geological Survey Science Publishing Network, Madison, Wis.

Michelle M. Greenwood, Reports Specialist, U.S. Geological Survey, Middleton, Wis.

Jennifer L. Bruce, Geographer, U.S. Geological Survey, Middleton, Wis.

James L. Kennedy, Geographer, U.S. Geological Survey, Middleton, Wis.

Laura L. Nelson, Office Automation Assistant, Middleton, Wis.

\section{Approving Official}

Kevin J. Breen, Bureau Approving Official, Hydrologist, U.S. Geological Survey, New Cumberland, Penn. 



\title{
Water Quality, Hydrology, and Simulated Response to Changes in Phosphorus Loading of Mercer Lake, Iron County, Wisconsin, with Special Emphasis on the Effects of Wastewater Discharges
}

\author{
By Dale M. Robertson, Herbert S. Garn, William J. Rose, Paul F. Juckem, and Paul C. Reneau
}

\section{Abstract}

Mercer Lake is a relatively shallow drainage lake in north-central Wisconsin. The area near the lake has gone through many changes over the past century, including urbanization and industrial development. To try to improve the water quality of the lake, actions have been taken, such as removal of the lumber mill and diversion of all effluent from the sewage treatment plant away from the lake; however, it is uncertain how these actions have affected water quality. Mercer Lake area residents and authorities would like to continue to try to improve the water quality of the lake; however, they would like to place their efforts in the actions that will have the most beneficial effects. To provide a better understanding of the factors affecting the water quality of Mercer Lake, a detailed study of the lake and its watershed was conducted by the U.S. Geological Survey in collaboration with the Mercer Lake Association. The purposes of the study were to describe the water quality of the lake and the composition of its sediments; quantify the sources of water and phosphorus loading to the lake, including sources associated with wastewater discharges; and evaluate the effects of past and future changes in phosphorus inputs on the water quality of the lake using eutrophication models (models that simulate changes in phosphorus and algae concentrations and water clarity in the lake).

Based on analyses of sediment cores and monitoring data collected from the lake, the water quality of Mercer Lake appears to have degraded as a result of the activities in its watershed over the past 100 years. The water quality appears to have improved, however, since a sewage treatment plant was constructed in 1965 and its effluent was routed away from the lake in 1995 . Since 2000, when a more consistent monitoring program began, the water quality of the lake appears to have changed very little. During the two monitoring years (MY) 2008-09, the average summer near-surface concentration of total phosphorus was $0.023 \mathrm{mg} / \mathrm{L}$, indicating the lake is borderline mesotrophic-eutrophic, or has moderate to high concentrations of phosphorus, whereas the average summer chlorophyll $a$ concentration was $3.3 \mathrm{mg} / \mathrm{L}$ and water clarity, as measured with a Secchi depth, was $10.4 \mathrm{ft}$, both indicating mesotrophic conditions or that the lake has a moderate amount of algae and water clarity.

Although actions have been taken to eliminate the wastewater discharges, the bottom sediment still has slightly elevated concentrations of several pollutants from wastewater discharges, lumber operations, and roadway drainage, and a few naturally occurring metals (such as iron). None of the concentrations, however, were high enough above the defined thresholds to be of concern.

Based on nitrogen to phosphorus ratios, the productivity (algal growth) in Mercer Lake should typically be limited by phosphorus; therefore, understanding the phosphorus input to the lake is important when management efforts to improve or prevent degradation of the lake water quality are considered. Total inputs of phosphorus to Mercer Lake were directly estimated for MY 2008-09 at about $340 \mathrm{lb} / \mathrm{yr}$ and for a recent year with more typical hydrology at about $475 \mathrm{lb} / \mathrm{yr}$. During these years, the largest sources of phosphorus were from Little Turtle Inlet, which contributed about 45 percent, and the drainage area near the lake containing the adjacent urban and residential developments, which contributed about 24 percent. Prior to 1965, when there was no sewage treatment plant and septic systems and other untreated systems contributed nutrients to the watershed, phosphorus loadings were estimated to be about 71 percent higher than during around 2009. In 1965, a sewage treatment plant was built, but its effluent was released in the downstream end of the lake. Depending on various assumptions on how much effluent was retained in the lake, phosphorus inputs from wastewater may have ranged from 0 to $342 \mathrm{lb}$. Future highway and stormwater improvements have been identified in the Mercer Infrastructure Improvement Project, and if they are done with the proposed best management practices, then phosphorus inputs to the lake may decrease by about $40 \mathrm{lb}$.

Eutrophication models [Canfield and Bachman model (1981) and Carlson Trophic State Index equations (1977)] were used to predict how the water quality of Mercer Lake should respond to changes in phosphorus loading. A relatively 
linear response was found between phosphorus loading and phosphorus and chlorophyll $a$ concentrations in the lake, with changes in phosphorus concentrations being slightly less (about 80 percent) and changes in chlorophyll $a$ concentrations being slightly more (about 120 percent) than the changes in phosphorus loadings to the lake. Water clarity, indicated by Secchi depths, responded more to decreases in phosphorus loading than to increases in loading.

Results from the eutrophication models indicated that the lake should have been negatively affected by the wastewater discharges. Prior to 1965 , when there was no sewage treatment plant effluent and inputs from the septic systems and other untreated systems were thought to be high, the lake should have been eutrophic; near the surface, average phosphorus concentrations were almost $0.035 \mathrm{mg} / \mathrm{L}$, chlorophyll $a$ concentrations were about $7 \mu \mathrm{g} / \mathrm{L}$, and Secchi depths were about $6 \mathrm{ft}$, which agreed with the shallower Secchi depths during this time estimated from the sediment-core analysis. The models indicated that between 1965 and 1995, when the lake retained some of the effluent from the new sewage treatment plant, water quality should have been between the conditions estimated prior to 1965 and what was expected during typical hydrologic conditions around MY 2008-09. The models also indicated that if the future Mercer Infrastructure Improvement Project is conducted with the best management practices as proposed, the water quality in the lake could improve slightly from that measured during 2006-10.

Because of the small amount of phosphorus that is presently input into Mercer Lake any additional phosphorus added to the lake could degrade water quality; therefore, management actions can usefully focus on minimizing future phosphorus inputs. Phosphorus released from the sediments of a degraded lake often delays its response to decreases in external phosphorus loading, especially in shallow, frequently mixed systems. Mercer Lake, however, remains stratified throughout most of the summer, and phosphorus released from the sediments represents only about 6 percent, or a small fraction, of the total phosphorus load to the lake. Therefore, the phosphorus trapped in the sediments should minimally affect the long-term water quality of the lake and should not delay the response in its productivity to future changes in nutrient loading from its watershed.

\section{Introduction}

Mercer Lake is a relatively shallow lake with surfacewater inflows and outflows (a "drainage lake") in the Northern Lakes and Forests Ecoregion (Omernik and others, 2000) in Iron County in north-central Wisconsin. The town of Mercer is located on the north side of the lake, between Mercer Lake and Grand Portage Lake (fig. 1). The area near Mercer Lake has gone through many changes since 1894, when the first train arrived in the area and was followed by early settlers, roads, mills, stores, and other businesses. Historically, iron mines and the lumber industry were very important for this area, but more recently, the area has become very popular for fishing and other outdoor activities. Because of the many uses for the lake and surrounding area, the lake is an important resource for Iron County. The popularity of the lake has resulted in additional development around Mercer Lake, and residents feel that this development and past activities in the Mercer Lake watershed, especially historical wastewater discharges to the lake, have affected the quality of the lake and its sediments. Despite actions to reduce the sewage and chemical input to the lake, Mercer Lake residents believe that the historical addition of nutrients in sewage may have and still does affect the water quality and plant and algal productivity in the lake and that the addition of chemicals, especially from lumber operations and street use, may have altered the quality of the sediments in the lake. Residents believe that water quality of the lake may have improved, but water quality continues to be poorer than it was historically. In 2006, residents felt that the amount of muck in the lake had increased significantly and feel it dominates the bottom substrate, and both residents and the Wisconsin Department of Natural Resources (WDNR) believe that aquatic weeds in the lake are a problem. Residents are also concerned about how future development in the watershed will affect the water quality of the lake. Mercer Lake area residents and authorities would like to improve the water quality of the lake; therefore, understanding the factors affecting water quality, especially the effects of past wastewater discharges, is very important.

To obtain a better understanding of the factors affecting the water quality of Mercer Lake, the U.S. Geological Survey (USGS) conducted a detailed study from 2007 to 2011 in collaboration with the Mercer Lake Association. This study was partially funded through the Cooperative Water Program of the USGS in cooperation with the Mercer School District, and the Lake Protection Grant Program of the WDNR. The results of this study are described in this report.

\section{History of Activities near Mercer Lake}

In the 1700 s and 1800 s, the area near Mercer Lake was relatively pristine, except for a relatively large Chippewa Indian village located near the lake (Outdoor Network, Inc., 2011). Local residents remember the Chippewa camps being occupied until the early 20th century. The area near the lake remained relatively unaffected by development until the 1880 s, when iron mining became an important industry in Iron County and the lumber industry moved into northern Wisconsin. To support these activities, railroad lines were extended into northern Wisconsin, making the area truly accessible for the first time. The mining boom created a demand for timber to build mines, and villages sprang up to support them. Most of the growth around Mercer Lake, other than the Chippewa village, began in 1894 when the first train arrived, and with it brought early settlers who needed roads, mills, stores and other businesses (table 1). The first Mercer 


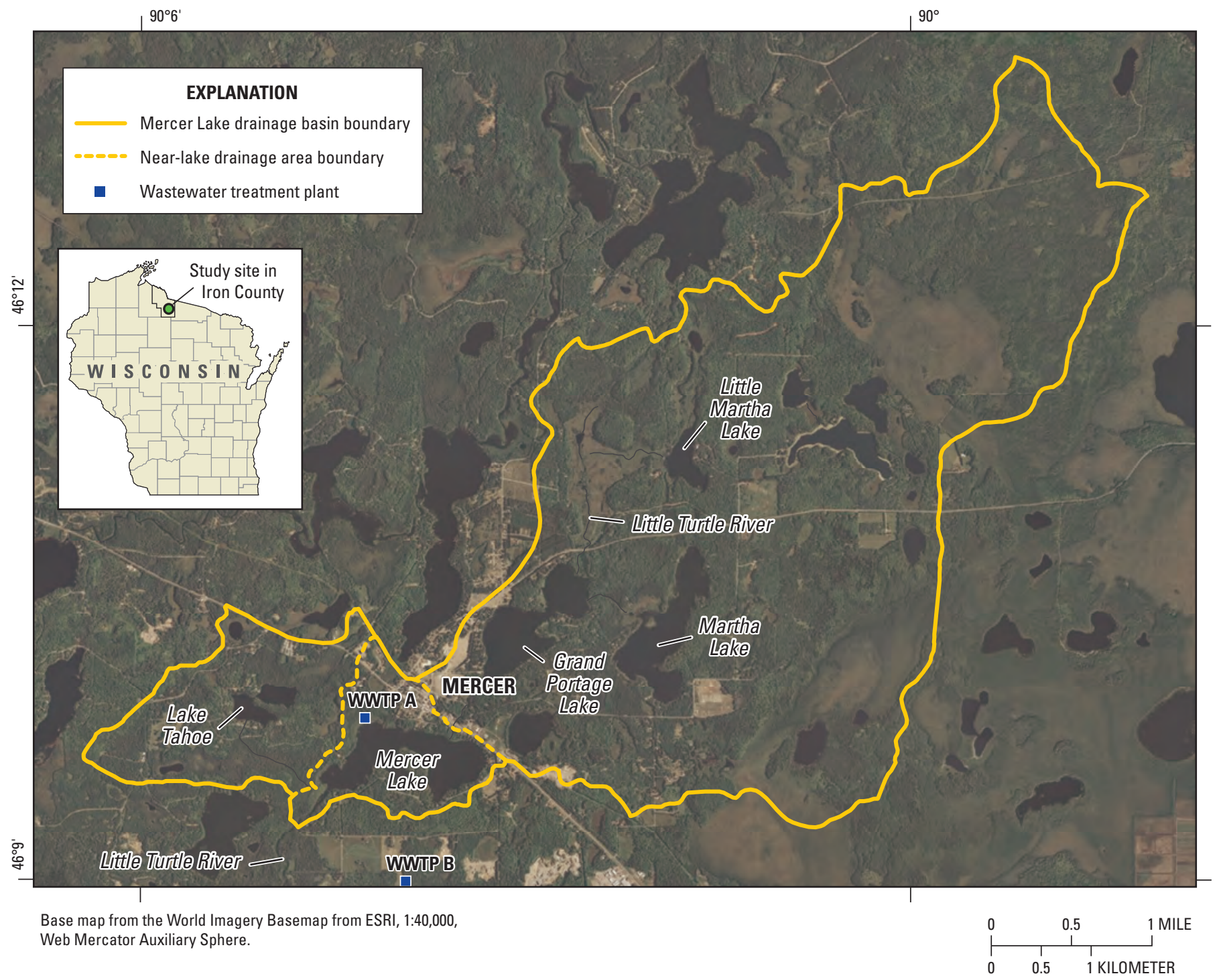

Figure 1. 2010 Aerial photo of Mercer Lake, Iron County, Wis., with its watershed delineated. The original (WWTP A) and 2012 (WWTP B) locations of the wastewater treatment plants are identified on the figure.

school was erected in 1894. Mercer was established as a town in 1909, along the north shore of Mercer Lake. The town was named after John Mercer, a timberman. In 1910, the population of Mercer was 311 (table 2).

In the late $1800 \mathrm{~s}$, lumbering flourished and Mercer became a well-established community in northern Wisconsin. Initially, pine logs from the Mercer-Manitowish area were floated down the Manitowish and Turtle Rivers, into the Flambeau River, to the downstream sawmills (Outdoor Network, Inc., 2011). Unmanaged logging took its toll on the area, bringing forest fires in 1911 that burned many acres and threatened lives. Following clear cutting of the forest, the vast barren areas were burned, rather than replanted, in the hope of providing good farm land, but farming never became a major industry in Iron County. Soon most of the desirable pine trees had been harvested from Iron County, leaving behind considerable hemlock and hardwoods. These trees were too heavy to log and transport by available methods, resulting in the establishment of many smaller mills closer to areas of hardwood growth and the available railroad lines. In the late 1930s, a moderate scale sawmill was established between Mercer and Grand Portage Lakes.

In the 1930s, Mercer became a popular vacation area for fishing and hunting (Outdoor Network, Inc., 2011). In 1930, the population of Mercer was 666 (table 2). Cash crop agriculture never reached significant levels in Iron County; at best, the logging camps and mines in the area created a demand for small-scale truck farming, and hay was grown for livestock. By the 1940s and 1950s, most of the small subsistence farms were either abandoned or absorbed by larger operations. Currently, limited dairy farming is the main agricultural activity in the more fertile part of northern Iron County. 
Table 1. Chronological history of major activities potentially affecting the water quality of Mercer Lake, Iron County, Wis.

[WDNR, Wisconsin Department of Natural Resources]

\begin{tabular}{|c|c|c|}
\hline Date & Activity & Reference \\
\hline 1894 & $\begin{array}{l}\text { Early settlers and first Mercer school established with the arrival of the } \\
\text { railroad }\end{array}$ & Outdoor Network, Inc., 2011. \\
\hline 1909 & Town of Mercer established & Town of Mercer, 2011. \\
\hline $1890 s-1920 s$ & Peak lumbering operations and cutting of pines and hardwoods & Outdoor Network, Inc., 2011. \\
\hline 1911 & Major forest fires in surrounding cutover areas & Outdoor Network, Inc., 2011. \\
\hline Late $1930 \mathrm{~s}$ & Establishment of a sawmill at the Midwest Forest Products industrial site & $\begin{array}{l}\text { D. Keefe, Mercer Lake Association, written } \\
\text { commun., } 2010 .\end{array}$ \\
\hline 1965 & $\begin{array}{l}\text { Wastewater treatment plant constructed and sewage effluent pipe installed to } \\
\text { discharge near the outlet of Mercer Lake }\end{array}$ & Mercer Lake Association, 2007. \\
\hline $1967-68$ & $\begin{array}{l}\text { Lumber debarking and shipping company started at the Midwest Forest } \\
\text { Products site }\end{array}$ & $\begin{array}{l}\text { D. Keefe, Mercer Lake Association, written } \\
\text { commun., } 2010 .\end{array}$ \\
\hline 1973, 1976 & $\begin{array}{l}\text { Dye tracer and water-quality studies done by WDNR to evaluate the effect } \\
\text { of sewage effluent discharge near the lake outlet in response to continued } \\
\text { complaints about water quality }\end{array}$ & $\begin{array}{l}\text { L. Sridharan and B. Zellmer, Wisconsin } \\
\text { Department of Natural Resources, written } \\
\text { commun., } 1980 \text {. }\end{array}$ \\
\hline $1987-1990$ & $\begin{array}{l}\text { Mercer treatment plant disinfection violations of discharge permit; continu- } \\
\text { ing complaints about water quality }\end{array}$ & $\begin{array}{l}\text { Wisconsin Department of Natural Resources, } \\
\text { written commun., various dates. }\end{array}$ \\
\hline 1994-2001 & $\begin{array}{l}\text { Underground storage tank at Midwest Forest Products site removed in } 1994 \\
\text { that was found to be leaking diesel fuel with some groundwater contamina- } \\
\text { tion; monitoring of the site completed in } 2000 \text {, and the monitoring site was } \\
\text { discontinued because it was thought to be of no risk in } 2001 \text { by WDNR }\end{array}$ & $\begin{array}{l}\text { J. Kreitlow, Wisconsin Department of Natural } \\
\text { Resources, written commun., } 2010 .\end{array}$ \\
\hline 1995 & $\begin{array}{l}\text { New treatment plant constructed south of Mercer to divert sewage out of the } \\
\text { Mercer Lake watershed }\end{array}$ & Mercer Lake Association, 2007. \\
\hline 1998 & Old treatment plant removed and the site restored & $\begin{array}{l}\text { C. Olson, Wisconsin Department of Natural } \\
\text { Resources, written commun., } 1998 .\end{array}$ \\
\hline 2005 & Lumber debarking and shipping company discontinued completely & $\begin{array}{l}\text { D. Keefe, Mercer Lake Association, written } \\
\text { commun., } 2010 .\end{array}$ \\
\hline
\end{tabular}

The saw mill has been the only significant industrial site near Mercer Lake. The saw mill burned down several times and was rebuilt by different owners. In 1967-68, a subsidiary of a paper company modified this site for debarking, treating, and shipping logs (table 1). This operation continued until about 2005 , but at that time it was operating only minimally (D. Keefe, Mercer Lake Association, written commun., 2010). The property contained an underground diesel fuel storage tank and was the subject of investigation and monitored for leaks (J. Kreitlow, Wisconsin Department of Natural Resources, written commun., 2010). The diesel fuel storage tank was removed in 1994 and was found to have contaminated local soil and groundwater, but no private water supplies were found to have been affected. Monitoring wells indicated that the site was no longer an environmental risk, and the site was allowed to close in 2001.

The first municipal wastewater treatment plant for the town of Mercer (Sanitary District \#1) was constructed in 1965 on the northwest shore of Mercer Lake (WWTP A in fig. 1), and it was designed to treat sewage from most of the town of Mercer, which had a population of 1,048 in 1960 (table 2). This secondary treatment facility employed an
Table 2. Population of the Town of Mercer, Iron County, Wis., from 1910 to 2010.

[Data from U.S. Census Bureau, 2011]

\begin{tabular}{cc}
\hline Year & Population \\
\hline 1910 & 311 \\
1920 & 567 \\
1930 & 666 \\
1940 & 936 \\
1950 & 974 \\
1960 & 1,048 \\
1970 & 1,003 \\
1980 & 1,425 \\
1990 & 1,325 \\
2000 & 1,732 \\
2010 & 1,407 \\
\hline
\end{tabular}


activated sludge process and aerobic digestion and had an average capacity of 85,000 gal/d (P. Budde, Strand Assoc., written commun., 1980). The effluent from the plant passed through a 3,000-ft long, 6-in. diameter asbestos pipe laid along the bottom of the lake and discharged near the Mercer Lake Outlet to the Little Turtle River. At that time, emergent and submergent aquatic vegetation was moderate to dense and the lake was considered to have an aquatic weed problem (Wisconsin Department of Natural Resources, 1970). It was believed that much of the effluent from the plant was not leaving the lake and may have been affecting the water quality of the lake. Therefore, two dye studies were conducted. Based on the first dye tracer study, conducted in 1973, the WDNR concluded that effluent was circulating back into the lake and was adversely affecting the water quality of the lake. It was recommended that the outfall line be extended farther into the outlet. The tracer study was repeated in 1976, and the WDNR then concluded that the effluent was being drawn out of the lake into the Little Turtle River. The reason for the different conclusions of the two studies was thought to be the result of the dye plume not being observed long enough in the 1973 survey (L. Sridharan and B. Zellmer, Wisconsin Department of Natural Resources, written commun., 1980). In addition to the possibility of the effluent not completely leaving the lake, the plant had frequent operating problems and often had difficulty meeting discharge permit limits. Operation difficulties and complaints about the treatment plant continued through the 1980s. The residents also believed that the pipe installed along the lake bottom may have ruptured soon after construction and spilled effluent directly into the main body of the lake until 1995 (D. Chidley, local resident, oral commun., 2006). A new treatment plant was constructed south of Mercer in 1995 (WWTP B in fig. 1), and it released its effluent outside of the watershed of the lake (Mercer Lake Association, 2007). The new facility is a sequencing batch reactor type of plant and discharges into three cells that seep into groundwater believed to flow away from the lake. The design flow for this plant is $82,700 \mathrm{gal} / \mathrm{d}$, adequate for 1,100 people. The old treatment plant on the lake was completely removed and the site was restored (C. Olson, Wisconsin Department of Natural Resources, written commun., 1998).

Since the late 1890 s, many factors have affected the quality of the water and sediments in Mercer Lake, such as nutrient inputs from septic and municipal effluent, chemical inputs from lumber mills and roads, and actions have been taken to ameliorate the effects of these factors (table 1).

\section{Shallow Lakes and Internal Phosphorus Loading}

Mercer Lake is relatively shallow lake. Shallow lakes, defined as having a maximum depth less than about $20 \mathrm{ft}$ (Osgood and others, 2002), typically experience only short periods of stratification, when the cooler, more dense, bottom water (hypolimnion) does not mix with the warmer, less dense, surface water (epilimnion), rather than a single extended period of stratification from early summer through early fall. Lakes in which water mixes frequently throughout the openwater period are called "polymictic," whereas lakes in which water mixes only during spring and fall and have extended periods of stratification in summer and under the ice are called "dimictic." Deeper lakes with relatively large surface areas may also be prone to frequent deep mixing. Osgood (1988) described the functional aspects of mixing based on the mean depth and surface area of lakes in terms of the Osgood Index. The Osgood Index is defined as the mean depth ( $\mathrm{z}$, in meters) of a waterbody divided by the square root of the surface area (A, in square kilometers), or $\mathrm{z} / \mathrm{A}^{0.5}$. The Osgood Index is used to describe the degree to which a lake or reservoir is likely to mix because of the forces of wind. Lakes with Osgood Index values greater than 9 generally are dimictic, and lakes with Index values less than 4 tend to be polymictic. Mercer Lake has an Osgood Index of 3.6; therefore, the lake should be polymictic. However, given that the lake has two basins (fig. 1), only part of the surface area is exposed to the wind at any time. The Osgood Index of the East Basin of the lake is 6.1 and the West Basin is 4.2; therefore, this indicates that both basins may be between these two categories and may mix intermittently.

When deep water of a productive lake (a lake with abundant plants or algae) becomes isolated from surface mixing because of thermal stratification, the bottom water often becomes anaerobic or devoid of dissolved oxygen because of the loss of oxygen associated with the decomposition of organic substances. When oxygen is completely depleted (anoxia) near the bottom sediment, the rate of phosphorus release from the deep sediments (termed "internal loading") often increases dramatically (Mortimer, 1941). Typically, in deeper, dimictic lakes, phosphorus released from the deep sediments is contained in the hypolimnion of the lake and is released to the epilimnion primarily at fall turnover. Therefore, phosphorus concentrations near the surface (termed "nearsurface concentrations") in dimictic lakes usually remain stable or decrease as summer progresses (Welch and Cooke, 1995). In polymictic lakes, however, when the deeper water becomes anaerobic during the short periods of stratification and phosphorus is released from the sediments, the frequent mixing events deliver the phosphorus to the surface of the lake throughout summer. The frequent mixing results in nearsurface concentrations of phosphorus increasing throughout the summer and the lake being very productive in late summer (Welch and Cooke, 1995). Polymictic lakes are extremely vulnerable to phosphorus contributed from areas outside of the lake (termed "external loading") and difficult to rehabilitate because the high rate of internal loading usually does not quickly respond to decreases in external phosphorus inputs (Newton and Jarrell, 1999; Nurnberg, 1998; Welch and Cooke, 1995).

Shallow lakes typically have two alternative stable states - phytoplankton (algae) dominated or macrophyte (plant) dominated (Newton and Jarrell, 1999). In moderate densities, macrophytes are beneficial in these lakes because 
they keep sediment from being resuspended by the wind and, therefore, help improve water clarity. Macrophytes also provide a place for attached algae to grow and remove phosphorus from the water column. If the macrophytes are removed or if external phosphorus inputs increase, the lake can shift from a macrophyte-dominated state to an algal-dominated state. Once a lake is in the algal-dominated state, macrophytes have a difficult time reestablishing themselves, because algae reduce the penetration of light through the water. Of these two conditions, it is commonly believed that the macrophyte-dominated state, as in Mercer Lake, is more desirable for human and biological use than the algal-dominated state (Newton and Jarrell, 1999). It is believed that Mercer Lake has more macrophytes than it once had, but macrophytes may have always been common in the lake.

Although the phosphorus load to Mercer Lake is believed to have decreased as a result of remediation efforts in the watershed (table 1), the internal phosphorus load may limit the response of the lake to decreases in external phosphorus loading. The impact of this internal phosphorus load in delaying the response in a lake's productivity to decreases in external nutrient loading has been documented in several lakes (Larsen and Mercier 1976; Larsen and others, 1979 and 1981; Robertson and Rose, 2008). Without knowing the importance of internal loading, it is not possible to predict with any degree of confidence how it could delay future improvements in the water quality of the lake.

\section{Lake-Sediment Quality}

The bottom sediments of a lake can provide a historical record of the chemical inputs to the lake, because many substances entering the lake eventually are deposited in the sediments in the deeper areas. Many organic chemicals, or hydrophobic compounds, are insoluble and have strong tendencies to accumulate in the sediments. Because of the tendency for these substances to be deposited in bottom sediments, much information about the history of chemical and particulate inputs may be obtained by analyzing sediment samples. Some elements, such as phosphorus, can migrate through the lake sediments and be released back into the water column (resolubilized) when environmental conditions such as dissolved oxygen, $\mathrm{pH}$, and temperature change; therefore, other indicators of past nutrient conditions are needed to examine historical changes in lake productivity. Changes in the assemblages of diatoms (a type of phytoplankton) in the lake sediments are often used to infer historical changes in the nutrient concentrations in the water column of lakes (Garrison, 2005).

Anthropogenic (those resulting from human activity) contaminants are deposited into lakes from the atmosphere, from point sources such as sanitary and storm sewers, industrial facilities, lumbering operations, and from nonpoint sources such as from urban and agricultural areas. The concentration and bioavailability (the degree to which a substance is available to living creatures) of contaminants in sediments can be major issues of concern in some areas because of their ability to persist and accumulate in sediment and aquatic organisms. Since the late 1890s, it is believed that the main anthropogenic contaminants that have entered Mercer Lake were from point sources such as sanitary and storm sewers, lumbering operations, and general urban areas (table 1). For many Midwest lakes, agricultural activities have strongly affected water quality; however for Mercer Lake, contaminants from agricultural activities are not believed to have had significant effects.

\section{Purpose and Scope}

The primary purposes of this report are to describe the conditions in Mercer Lake as observed in 2008-09, discuss factors that may delay expected improvements in water quality, and provide information useful for consideration of further measures that may improve the water quality of this lake in the face of increases in property development. Specifically, this report (1) describes the present and historical water quality of Mercer Lake, (2) quantifies water and phosphorus budgets, including contributions from internal loading, on the basis of data collected from November 2007 through October 2009; (3) presents the results of model simulations that demonstrate the potential effects of changes in phosphorus inputs on lakewater quality, including effects from wastewater discharges; and (4) describes the sediment quality of the surficial sediments of Mercer Lake. Information from this study improves our knowledge of how lakes, in general, should respond to changes in wastewater discharges.

\section{Mercer Lake and Its Watershed}

Mercer Lake is a drainage lake in Iron County just south of Mercer, Wis. Mercer Lake is in the Little Turtle River Basin, the main stream flowing into and out of the lake (fig. 1). Grand Portage Lake is immediately upstream of Mercer Lake. An additional small tributary, the Tahoe Inlet (outlet stream from Lake Tahoe), flows into the lake on the west side near the outlet. After leaving the lake, the Little Turtle River flows into the Little Turtle Flowage, the Turtle-Flambeau Flowage, and then into the Flambeau River. In this study, the watershed was divided into three areas: the area upstream of the major inlet to the lake (the "upstream gaged area"), the Tahoe watershed, and the drainage area adjacent to the lake (the "near-lake area") that includes drainage from the storm drain immediately east of the boat launch (figs. 1 and 2).

The area and volume of Mercer Lake are 184 acres and 1,949 acre-ft as given on the 1968 WDNR lake survey maps. In this study, the morphometry of the lake was reevaluated on the basis of an aerial image obtained from the 2005 National Agricultural Imagery Program (U.S. Department of Agriculture, 2006). By using geographic information system (GIS) techniques, the resulting surface area of Mercer Lake was determined to be 179 acres and the volume to be 1,793 acre- $\mathrm{ft}$ 


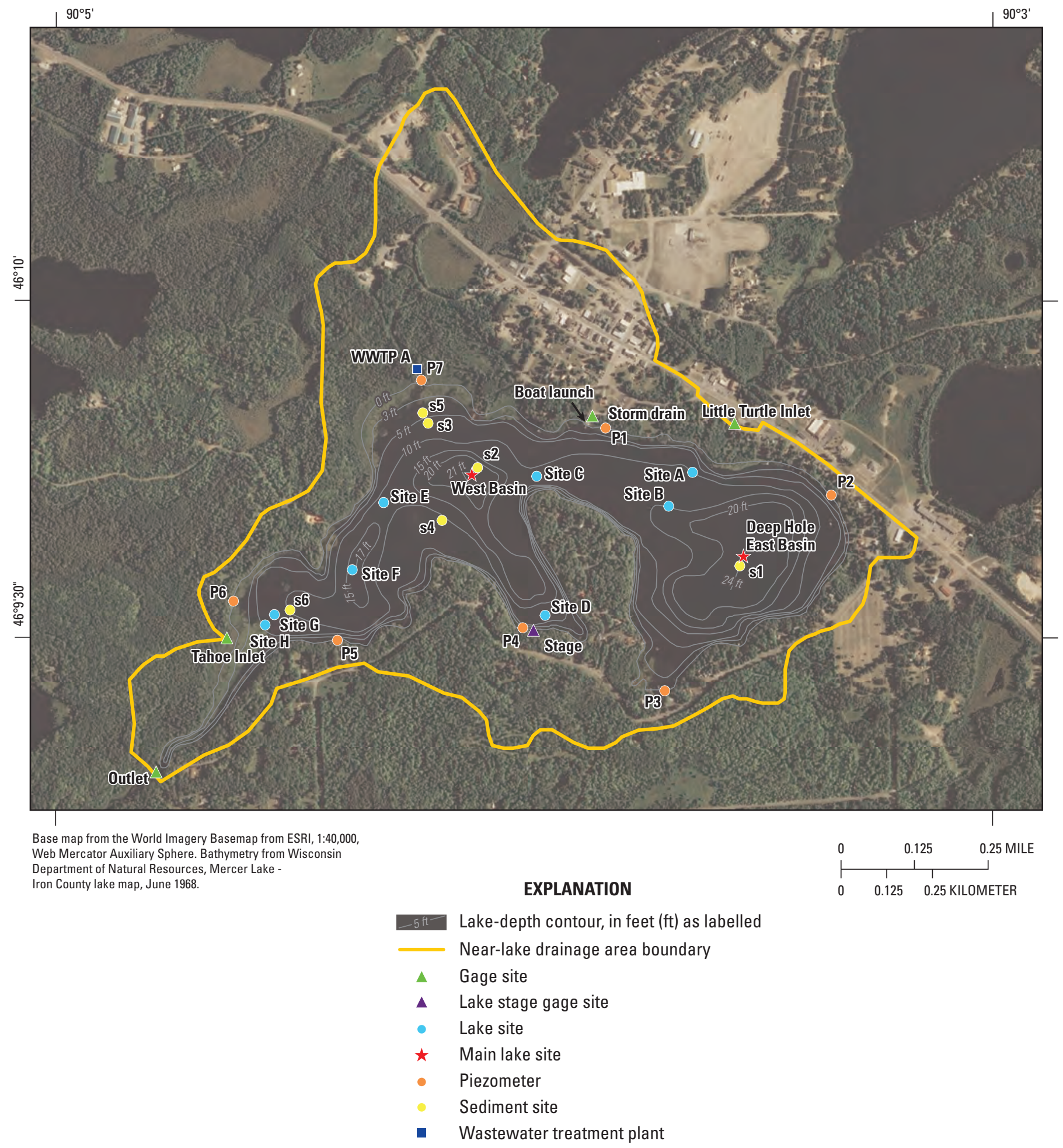

Figure 2. 2010 Aerial photo of Mercer Lake, Iron County, Wis. with the near-lake drainage area and surface-water and groundwater data-collection sites identified. The location of the original wastewater treatment plant (WWTP A), and the contours of similar depth are identified on the figure. 
Table 3. Morphometric characteristics of Mercer Lake, Iron County, Wis.

[NA, not available]

\begin{tabular}{lccc}
\hline \multicolumn{1}{c}{ Characteristic (units) } & Entire Lake & East Basin & West Basin \\
\hline Area (acres) & 179 & 84 & 95 \\
Volume (acre-feet) & 1,793 & 976 & 817 \\
Maximum depth (feet) & 24.0 & 24.0 & 21.0 \\
Mean depth (feet) & 10.0 & 11.7 & 8.6 \\
$\begin{array}{l}\text { Residence time, study } \\
\text { period (years) }\end{array}$ & 0.46 & $\mathrm{NA}$ & $\mathrm{NA}$ \\
$\begin{array}{c}\text { Residence time-typical } \\
\quad \text { hydrology (years) }\end{array}$ & 0.33 & $\mathrm{NA}$ & $\mathrm{NA}$ \\
$\begin{array}{l}\text { Osgood Index } \\
\text { Msod }\end{array}$ & 3.6 & 6.1 & 4.2 \\
\hline
\end{tabular}

${ }^{1}$ Osgood and others, 2002.

(table 3 ). The area and volume determined in this study were used for all of the computations in this report. Based on this information, the mean depth of the lake is $10 \mathrm{ft}$. Mercer Lake is comprised of two basins: the East Basin with a maximum depth of $24 \mathrm{ft}$ and the West Basin with a maximum depth of $21 \mathrm{ft}$. The two basins are separated by a sill with a maximum depth of about 10-15 ft.

The watershed of Mercer Lake consists of surficial glacial deposits, including pitted outwash and other ice contact deposits, ground moraine and end moraines composed of sand and gravel. The basin has low to moderate relief and flat to steep slopes with many swamps and several upstream lakes (Grand Portage Lake immediately upstream, and Martha, Little Martha and other small lakes farther upstream in the drainage). The depth of the surficial materials may be up to $100 \mathrm{ft}$ over igneous and metamorphic bedrock (Young and Hindall, 1972; Mudrey and others, 1982). Soils of the rolling-to-undulating uplands are primarily sandy loam, loamy sand, and sand, with permeabilities of 2.5 to $5 \mathrm{in} / \mathrm{hr}$ or more, and muck or peat soils in the wetlands (Hole and others, 1968; Oakes and Cotter, 1975). This glacial drift is the only significant source of groundwater, yielding moderate to large quantities of water. Scattered throughout the area are many small closed depressions, or internally drained areas commonly with ponds or wetlands but without outlets, that do not contribute surface runoff to the lakes.

\section{Land Use and Population}

Land use in the watershed is primarily a mixture of forest (74.9 percent), wetlands (6.6 percent), open water (8.5 percent), and low-density residential (5.9 percent), with smaller areas of urban (2.2 percent), grassland/shrubland (1.1 percent), agriculture ( 0.4 percent), and golf courses (0.4 percent) (table 4; Multi-Resolution Land Characteristics Consortium, 2001). Therefore, agriculture inputs of nutrients should not be a factor in this area, but inputs from urban and low-density residential uses may be significant, especially along the north shore of the Lake.

The town of Mercer generally has not experienced the recent rapid growth that other areas in the northwoods have had (Garn and others, 2010), and the town retains much of its "northwoods character." Decennial censuses since 1910 exhibit variable population growth, with larger increases in the 1930s, 1970s, and 1990s (fig. 3). The population has increased from 311 in 1910 to 1,732 in 2000; however, in 2010, the population decreased to 1,407 , a loss of 19 percent from 2000.

Table 4. Land use/land cover in the contributing areas to Mercer Lake, Iron County, Wis.

[Data from the Multi-Resolution Land Characteristics Consortium, 2001]

\begin{tabular}{|c|c|c|c|c|c|c|c|c|c|}
\hline Basin/drainage & $\begin{array}{c}\text { Area } \\
\text { (acres) }\end{array}$ & $\begin{array}{c}\text { Forest } \\
\text { (percent) }\end{array}$ & $\begin{array}{l}\text { Wetlands } \\
\text { (percent) }\end{array}$ & $\begin{array}{c}\text { Low-density } \\
\text { residential } \\
\text { (percent) }\end{array}$ & $\begin{array}{l}\text { Moderate- } \\
\text { and high- } \\
\text { density } \\
\text { residential } \\
\text { (percent) }\end{array}$ & $\begin{array}{c}\text { Agriculture } \\
\text { (percent) }\end{array}$ & $\begin{array}{c}\text { Grassland/ } \\
\text { shrubland } \\
\text { (percent) }\end{array}$ & $\begin{array}{c}\text { Golf } \\
\text { course } \\
\text { (percent) }\end{array}$ & $\begin{array}{c}\text { Open } \\
\text { water } \\
\text { (percent) }\end{array}$ \\
\hline $\begin{array}{l}\text { Upstream gaged } \\
\text { area }\end{array}$ & 6,564 & 75.0 & 7.7 & 5.3 & 1.3 & 0.5 & 1.0 & 0.0 & 9.2 \\
\hline Entire watershed & 7,625 & 74.9 & 6.6 & 5.9 & 2.2 & 0.4 & 1.1 & 0.4 & 8.5 \\
\hline
\end{tabular}




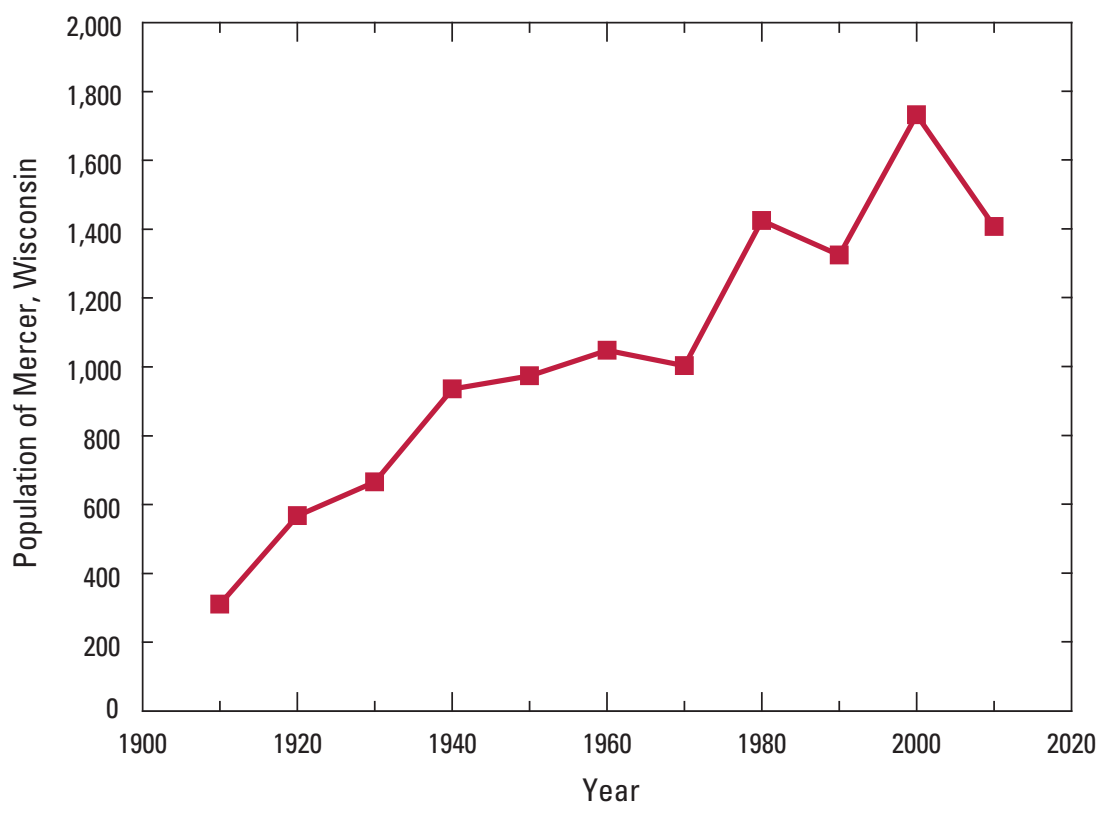

Figure 3. Population of Mercer, Iron County, Wis., 1910-2010.

\section{Data-Collection Methods and Sites}

As part of this study, USGS personnel collected stream and lake data from November 2007 through October 2009. In addition, water-quality data for the lake were collected by the WDNR and volunteers from the Lakes Association as part of the WDNR's Wisconsin Citizen Lake Monitoring Program (Wisconsin Department of Natural Resources, 2008). Data collected by the WDNR were supplied by J. Vennie (Wisconsin Department of Natural Resources, written commun., 2009). Citizen Lake Monitoring data were obtained from the WDNR's Surface Water Integrated Monitoring System (SWIMS) database (http://dnr.wi.gov/lakes/clmn/Stations. aspx? location $=26$, accessed December 12, 2011). All available data, but primarily near-surface concentrations of total phosphorus and chlorophyll $a$, plus Secchi depths, were used to characterize long-term changes in the water quality of the lake; however, only data collected from November 1, 2007, to October 31, 2009, were used to describe the hydrology and phosphorus inputs to the lake. This latter period was divided into two monitoring years (MY): November 2007 through October 2008 (hereafter referred to as "MY 2008") and November 2008 through October 2009 (hereafter referred to as "MY 2009").

\section{Lake-Stage and Water-Quality Monitoring}

A continuously recording (at 15-minute intervals) lakestage gage was installed and operated on the southwest side of Mercer Lake (fig. 2). The gage was operated for the 2-year monitoring period.
Water-quality data for the lake were collected by the WDNR from 1973 to 1974 as part of a statewide assessment and during 1975 to 1976 and 2000-02 as part of other general assessments. In 2001, volunteers from the local community and the Mercer Lake Association (Citizen Monitoring) began monitoring the lake. From 2001 to 2002, only Secchi depths were measured at the Deep Hole Site in the East Basin (fig. 2). During 2004, 2005, and 2007, only Secchi depths were measured near the deepest location in the West Basin (also referred to as the home base site). From 2006 to 2011, Secchi depth, near-surface total phosphorus, and chlorophyll $a$ were measured at the Deep Hole site in the East Basin; all three parameters were also measured in the West Basin during 2008 and 2009, and Secchi depth was measured in 2011. All Citizen Lake Monitoring was done in accordance with protocols described by Wickman and Herman (2005). In 2008 and 2009, USGS sampling was done at the Deep Hole site in the East Basin and near the deepest location in the West Basin (fig. 2). USGS protocols involved collecting profiles of water temperature, dissolved oxygen, specific conductance, and $\mathrm{pH}$ with a multiparameter meter, and water clarity (Secchi depth) with a standard 8-in.-diameter black-and-white Secchi disk during each visit. Near-surface samples were collected with a Van Dorn sampler and were analyzed for total phosphorus and chlorophyll $a$ concentrations and, during midsummer, for various nitrogen species (nitrite plus nitrate and Kjeldahl nitrogen). Samples collected near the lake bottom (near-bottom samples) were collected about $3 \mathrm{ft}$ above the sediment-water interface and were analyzed for total phosphorus concentration. In addition, water samples were collected at the Deep Hole site in the East Basin during spring turnover in 2008 and 2009 and were analyzed for common ions and other 
characteristics such as color, turbidity, alkalinity, total dissolved solids, and silica. Almost all of the monitoring was conducted during the open water season, except during 1974-75 and 2008-09, when sampling was also done in March through the ice.

All of the lake-stage, water-quality, and quality-assurance data collected by the USGS were published in the USGS online Annual Water Data Report series (U.S. Geological Survey, 2009-10), which is available on the World Wide Web at $h t t p: / / w d r$ water.usgs.gov/index.html.

In addition to the sampling described above, the USGS conducted a synoptic survey on March 26, 2008, to determine the extent of low dissolved oxygen concentrations (hypoxia) under the ice. During this survey, profiles of water temperature, dissolved oxygen, specific conductance, and $\mathrm{pH}$ were collected with a multiparameter meter at 10 locations throughout the lake (Sites A-H and the main lake sites in fig. 2).

\section{Lake Classification}

One method of classifying the water quality of a lake is with trophic state index (TSI) values based on near-surface concentrations of total phosphorus, chlorophyll $a$, and Secchi depths, as developed by Carlson (1977). The indices were developed to place these three characteristics on similar scales to allow comparison of different lakes. TSI values based on total phosphorus concentrations (TSI $)$, chlorophyll $a$ concentrations $\left(\mathrm{TSI}_{\mathrm{C}}\right)$, and Secchi depths $\left(\mathrm{TSI}_{\mathrm{SD}}\right)$ were computed for each sampling by use of equations $1-3$. The individual index values were averaged monthly, and the monthly average values were then used to compute summer (May through September) average TSI values:

$$
T S I_{P}=4.15+14.42 \text { (ln total phosphorus) }
$$

[total phosphous in milligrams per liter *1,000]

$$
\begin{gathered}
T S I_{C}=30.6+9.81[\ln \text { chlorophyll } a(\text { in micrograms per liter) }] \\
T S I_{S D}=77.12-14.41[\ln \text { Secchi depth (in feet) }]
\end{gathered}
$$

Oligotrophic lakes have TSI values less than 40; a limited supply of nutrients; typically have low phosphorus concentrations, low algal populations, and high water clarity; and contain oxygen throughout the year in their deepest zones (Wisconsin Department of Natural Resources, 1992). Mesotrophic lakes have TSI values between 40 and 50; a moderate supply of nutrients; a tendency to produce moderate algal blooms and moderate clarity; and occasionally have oxygen depletions in the deepest zones of the lake. Eutrophic lakes have TSI values greater than 50; a large supply of nutrients; severe waterquality problems, such as frequent seasonal algal blooms and poor clarity; and oxygen depletion is common throughout the deeper zones of the lake. Eutrophic lakes with TSI values greater than 60 are often further classified as hypereutrophic lakes, and they typically have even more severe water-quality problems, including frequent extensive algal blooms.

\section{Stream Monitoring}

Three stream sites (two tributary sites and one outlet site; fig. 2) were equipped with instrumentation to continuously monitor flow at 15-minute intervals. At all three sites, water level was measured to determine flow by use of standard stage-discharge relations (Rantz and others, 1982). Two tributary sites were monitored: the main inlet site, Little Turtle River at Garnet Street, station number 0535739503; and the storm drain outlet near the boat landing, station number 0535739504. At the storm drain, a 7-inch weir was installed to provide accurate flow estimates. A gaging station was installed at the bridge crossing the Little Turtle River at the Mercer Lake Outlet, station number 053573952. The data are stored and maintained in the USGS National Water Information System (NWIS) database.

Water samples were collected at the three monitoring sites by USGS staff or a local observer approximately monthly and during flow events by use of the Equal-Width-Increment (EWI) method (Edwards and Glysson, 1999) or by grab methods. Water samples were analyzed for concentrations of total phosphorus. Phosphorus loads for each site were then computed for the entire monitoring period using the Graphical Constituent Loading Analysis System (GCLAS; Koltun and others, 2006). GCLAS is a program developed by the USGS to estimate loads of water-quality constituents from instantaneous measurements of streamflow and constituent concentration, which collectively can be used to compute instantaneous loads. Generally, concentrations are linearly extrapolated between measurements except at the beginning and end of each event. Prior to the extrapolations, additional concentrations are often added to the time series to better describe concentrations just prior to an event and just following an event or to describe events without measured concentrations. Concentrations at the beginning of an event were estimated from concentrations measured during previous base-flow periods. Concentrations at the end of the events were estimated from concentrations measured shortly after the end of an event.

To estimate flow and phosphorus loading from the Tahoe watershed, intermittent discharge measurements and water samples were collected from a small tributary, the outlet stream from Lake Tahoe that enters Mercer Lake on the west side (Tahoe Inlet in fig. 2). All water samples were analyzed for total phosphorus. The measured flows were then correlated with the continuously recorded flow at the main inlet site on Little Turtle River to develop a regression relation between the two sites [Tahoe Flow $(\mathrm{cfs})=$ Little Turtle Flow $(\mathrm{cfs}) *$ $0.239-0.802]$. The regression relation and the daily flows at Little Turtle Creek were used to estimate daily flows at the Tahoe Inlet. Temporally varying offsets were then applied to all estimated flow data to force estimated flows to equal those measured at the outlet. Daily phosphorus loads from the Tahoe Inlet were determined by multiplying the volumetrically weighted concentration from all of the samples measured at the outlet by the estimated daily flow. 
All water-quality data and daily flows and loads were published in the USGS Water Data Report Series (U.S. Geological Survey, 2009-10), which is available on the World Wide Web at http://wdr.water.usgs.gov/.

\section{Estimating Input from the Ungaged Near-Lake Drainage Areas}

Smaller subwatersheds making up the area immediately around the lake, not including the storm drain near the boat landing (referred to herein as "ungaged near-lake area"; fig. 2) also contribute runoff to the lake. Drainage from ungaged near-lake areas includes runoff from areas drained by unchannelized direct runoff to the lake, runoff conveyed in numerous small channels, and additional runoff from the storm sewered parts of the town that flows overland to the lake when the capacity of the storm sewer is exceeded. Because of the complex nature of the sources of this runoff, the use of runoff coefficients was not practical. This near-lake runoff was estimated from the residuals in the mass-balance equation after all other inputs and outputs were determined, including inputs from groundwater. To temporally distribute the near-lake runoff, the runoff required to make the calculated change in the lake stage equal the measured (actual) change in the lake stage was calculated on a daily basis. Because of the inability to perfectly measure or estimate other inputs, outputs, and changes in lake stage, the calculations yielded negative runoff for some days, which is not possible in reality. To deal with this, runoff for the calculated negative days was assumed to equal zero; therefore, on those days when calculated runoff was positive, the calculated values needed to be adjusted (reduced) to offset the sum of the negative values. To make this adjustment, the positive daily flow values were multiplied by the ratio of the sum of the positive values minus the sum of the negative values divided by the sum of the positive values.

\section{Groundwater Monitoring}

Seven shallow, small-diameter piezometers (1/2-in.-diameter observation wells) were installed around the periphery of Mercer Lake (fig. 2) to help define areas contributing groundwater to the lake, determine the phosphorus concentration in the groundwater entering the lake, and quantify the phosphorus loading from groundwater. The piezometers were installed approximately $2-3 \mathrm{ft}$ below the water table, to depths of $5-8 \mathrm{ft}$. Groundwater gradients, which are determined from the differences in water elevation in the piezometers and elevation of the lake surface, in all of the piezometers were measured six times during the 2-year monitoring period: three times in the September-October early fall period, two times in the May-June early summer period, and once in March. In addition, water elevations in two of the piezometers were measured in November 2008. Dissolved phosphorus concentrations were measured in each piezometer for each of the early summer and early fall samplings if the gradient indicated flow toward the lake.
To provide information for the calibration of a local groundwater model (described in later sections), water-surface elevations of selected nearby lakes and streams were surveyed on September 2008 by use of a Real-Time Kinematic Global Positioning System (RTK-GPS). The elevations surveyed have an expected accuracy of about $0.1 \mathrm{ft}$. Concurrent base-flow discharge measurements were made at stream sites during the survey.

All lake, stream, and groundwater samples were analyzed by the Wisconsin State Laboratory of Hygiene (WSLH) in accordance with standard analytical procedures described in its "Manual of Analytical Methods, Inorganic Chemistry Unit" (Wisconsin State Laboratory of Hygiene, 1993).

\section{Lake-Sediment Analyses}

\section{Phosphorus Release Rates from Mercer Lake Sediments}

Release rates of phosphorus from the sediments during aerobic and anaerobic conditions (used to estimate internal loading) were determined from analysis of sediment cores collected at four locations in the lake (lake-monitoring sites and two auxiliary sites, sites s1-s4 in fig. 2) by using the sediment-core-incubation techniques described by James and Barko (1991). A Wildco sediment-core sampler equipped with acrylic core liners was used to collect the cores (fig. 4A). At the two deep lake-monitoring sites (s1 and s2), four cores were collected: two cores for aerobic analysis and two cores for anaerobic analysis. At the two shallow sites in the West Bay (s3 and s4), two cores were collected for aerobic analysis only. After retrieval, the core liners, containing both sediment and overlying water, were immediately sealed with rubber stoppers and stored in a protective container for shipping to the WSLH. Additional lake water was collected for incubation with the collected sediment.

At the WSLH, the sediment cores were carefully drained of overlying water. Then additional water, collected from the lake, was filtered and siphoned onto the sediment contained in each of the core liners. All of the liners containing the sediment were placed in the dark and incubated at a constant temperature (approximately $22^{\circ} \mathrm{C}$ ) for $1-2$ weeks. The incubation temperature was a constant temperature close to that above the sediments in Mercer Lake during summer.

The aerobic/anaerobic environment of each core was controlled in the laboratory by gently bubbling either air (aerobic environment) or nitrogen (anaerobic environment) through an air stone placed just above the sediment surface. The limited bubbling action insured complete mixing of the water column but did not disrupt the sediment. Eight of the cores (two from each location) were subjected to aerobic conditions and four of the cores (two each from the two deep lake-monitoring sites, s1 and s2) were subjected to anaerobic conditions. Therefore, all incubations were run in duplicate. 

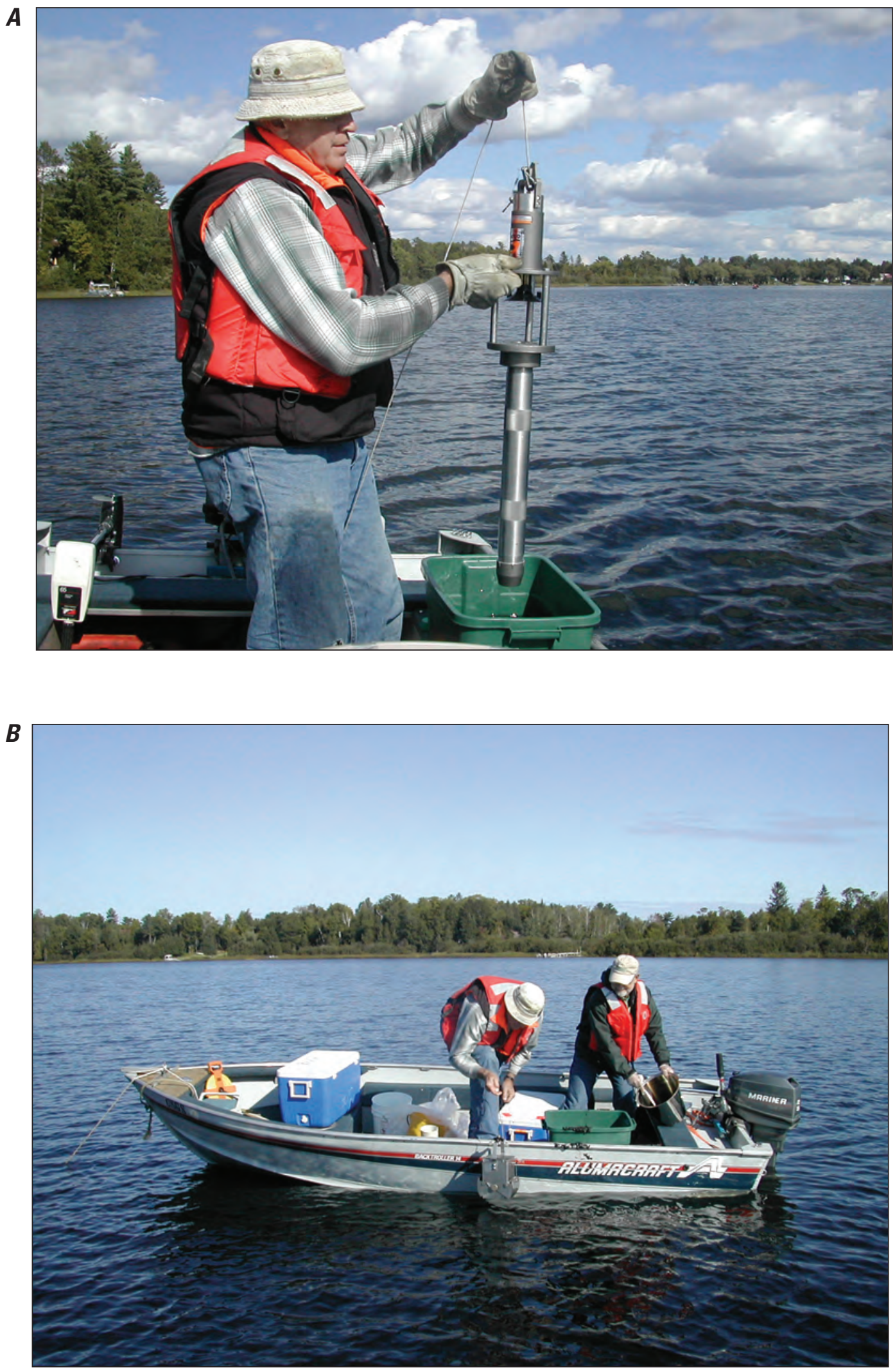

Figure 4. Photographs illustrating sediment-sample collection for $A$, phosphorus release analyses and $B$, composition analyses. 
Samples for soluble reactive phosphorus analysis were collected daily from water above the sediment for each core and filtered through a $0.45-\mathrm{mm}$ filter. The volume of water that was removed was replaced with an equivalent volume of lake water with a known concentration. Rates of phosphorus release from the sediments (in $\mathrm{lb} / \mathrm{ft}^{2} / \mathrm{d}$ ) were then calculated as a linear change in mass in the overlying water divided by the time and the cross-sectional area of the incubation core liner. All results were corrected for the water (and phosphorus) that was removed from above the core and replaced with lake water. All of the aerobic and anaerobic sediment release rates were then averaged to obtain an average aerobic release rate and an average anaerobic release rate.

The amount of phosphorus released from the sediment (internal loading) was obtained by summing the amount released from the aerobic and anaerobic areas. The area of anaerobic sediment was estimated from the depths at which a dissolved oxygen concentration of less than or equal to approximately $0.5 \mathrm{mg} / \mathrm{L}$ was measured in the profiles collected in the deepest areas of the lake, assuming that the dissolved oxygen concentrations were horizontally uniform throughout the lake. The area of aerobic sediment was computed by subtracting the area of anaerobic sediment and the area of sediment at depths less than $6.5 \mathrm{ft}$ from the total area. It was assumed that no phosphorus was released from areas less than 6.5 -ft deep, because these areas typically have little accumulated organic sediment. From the 2 years of profile data, the areas of aerobic and anaerobic sediment were estimated for specific dates throughout the year. The daily sediment release was then computed as the product of the release rates and the respective aerobic and anaerobic areas.

\section{Composition of Mercer Lake Sediments}

Surficial sediment samples from the lake bottom were collected from four locations in Mercer Lake: monitoring sites s1 and s2 in the East and West Basins, a shallow site in the near the original sewage treatment plant location, site s5, and a shallow site near the outlet of the lake where the pipe discharged its effluent, site S6 (fig. 2). In addition, a sediment sample was collected at a deep location in the northeast bay of Grand Portage Lake. Sediment samples for physical and nutrient analysis, trace elements, and organic compounds were collected on September 8 and 9, 2008, and for polychlorinated biphenyls (PCBs) analysis on October 8, 2008. The four sites in Mercer Lake were chosen to represent the variability in the lake and to ascertain the potential effects of the discharge from the sewage treatment plant. Sediments from Grand Portage Lake were examined to represent reference sediment conditions, because sediment from Grand Portage Lake should have had minimal affects from sewage input, urbanization, and industry.
Surficial sediment samples from approximately the top 2-in. layer of sediments were collected with an Ekman dredge (fig. $4 B$ ) for analyses of physical characteristics, nutrients, trace elements, PCBs and other organic compounds. Samples were deposited in pre-cleaned polypropylene or pre-combusted glass jars as appropriate. Samples to be analyzed for trace elements and organic compounds were chilled in ice and sent to the USGS National Water Quality Laboratory (NWQL) in Denver Colo., and those analyzed for physical characteristics, nutrients, and PCB constituents were chilled in ice and sent to the WSLH. Analytical methods at NWQL followed approved USGS protocols (Fishman and others, 1994; Fishman and Friedman, 1989; Garbarino and Struzeski, 1998), and samples sent to the WSLH followed their approved protocols (Wisconsin State Laboratory of Hygiene, 1993).

Sediment samples were analyzed for a wide variety of constituents, including metals and wastewater indicators, to characterize the sediment quality. Analyses for trace metals were performed according to methods described in NWQL Schedule 316. Analyses for wastewater indicators were done according to methods described in NWQL Schedule 5433, which was developed for the determination of wastewater indicator compounds typically found in domestic and industrial wastewater. The wastewater analytical list contains about 60 individual compounds (Appendix 1), including surfactants, food additives, antioxidants, flame retardants, plasticizers, industrial solvents, disinfectants, pharmaceuticals, personalcare products, polycyclic aromatic hydrocarbons (PAHs), and high-use domestic pesticides (Burkhardt and others, 2006). Some of these compounds are known or suspected of disrupting endocrine functions in aquatic vertebrate organisms (see Appendix 1).

\section{Paleoecological Analysis}

A separate paleoecological study of the lake-bottom sediments of Mercer and Grand Portage Lakes was done by the WDNR, Bureau of Integrated Science Services, to determine the ages of the sediment from specific depths and to quantify historical changes in sedimentation rates in the lakes, changes in water clarity, and changes in the macrophyte community (Garrison, 2005). Sediments from the deep region of the West Basin of Mercer Lake (20 ft) and the northeast bay of Grand Portage Lake ( $32 \mathrm{ft}$ ) were extracted by use of a piston coring device on July 9, 2003, and then analyzed to reconstruct changes in the water clarity and macrophyte community in the lakes by examining changes in the diatom assemblages at different depths in the core. Results from Grand Portage Lake were used as reference conditions and were thought to have minimal effects of inputs from sewage treatment plant, and urban and residential development. 


\section{Stratification, Water Chemistry, and Trophic Conditions}

\section{Stratification and Dissolved Oxygen}

During MY 2008-09, Mercer Lake can be described as a dimictic lake, meaning that it typically undergoes two extended periods of mixing (often referred to as "turnover") during spring and fall and thermally stratifies during summer and winter. During summer, a weak thermocline (the depth interval where the temperature decreases rather abruptly) develops in late May to early June and remains established through September (fig. 5). The thermocline developed from about 13 to $16 \mathrm{ft}$ below the surface. Water temperatures in the deepest areas of the lake were from about 12 to $14^{\circ} \mathrm{C}$ in early summer (early June) and increased to about 16 to $18^{\circ} \mathrm{C}$ by late summer (early September). During summer, surface mixing penetrated down into the thermocline several times, but mixing was insufficient to cause complete mixing down to the bottom of the lake (fig. 5). The incomplete mixing was sufficient to cause bottom temperatures to increase throughout the summer. Temperature profiles collected in both basins demonstrated little horizontal variation in thermal stratification throughout the lake during summer.

Dissolved oxygen concentrations were near saturation throughout the lake from just after the ice melted until the lake stratified; however, once a thermocline developed, concentrations in the deep areas quickly decreased, while concentrations in shallow waters remained near saturation (fig. 5). By midJune, dissolved oxygen concentrations near the bottom of the deepest areas of the lake were almost zero (less than $0.5 \mathrm{mg} / \mathrm{L}$ ) and unable to support fish. This anaerobic condition in the bottom waters is common in eutrophic lakes (Wetzel, 1983). During late fall, the lake completely mixed, and dissolved oxygen concentrations at all depths were near saturation again. From the 2 years of data, it appeared that anaerobic conditions near the bottom developed about June 15 and lasted to about September 10.

Temperature and dissolved oxygen profiles were also collected under the ice in late winter. These profiles demonstrated that the lake was inversely stratified with cool water (near $0^{\circ} \mathrm{C}$ ) just below the ice and warming to about $5^{\circ} \mathrm{C}$ near the bottom. In the March profiles, very low dissolved oxygen concentrations were found: $2.4-2.6 \mathrm{mg} / \mathrm{L}$ under the ice and less than $1 \mathrm{mg} / \mathrm{L}$ about $5 \mathrm{ft}$ or more beneath the ice (about $6.5 \mathrm{ft}$ beneath the lake surface). Therefore, a synoptic survey was done on March 26, 2008, to determine the extent of hypoxia in the lake (fig. 6). The very low oxygen concentrations in the middle of the lake also occurred in almost all other areas, except near to where the Little Turtle River enters the lake (Site A). By late winter, dissolved oxygen concentrations greater than $5 \mathrm{mg} / \mathrm{L}$ were only found just beneath the ice and near the inlet. Dissolved oxygen concentrations throughout the lake were well below the Wisconsin state standard of $5 \mathrm{mg} / \mathrm{L}$ for warm-water lakes (Shaw and others, 1993), and typically below the 2-mg/L critical concentration for most fish.

\section{Water Chemistry}

Water in Mercer Lake is a little harder than most lakes in north-central Wisconsin, reflecting the igneous bedrock and glacial deposits in the area. The hardness was about 88 to $97 \mathrm{mg} / \mathrm{L}$ as calcium carbonate $\left(\mathrm{CaCO}_{3}\right)$, which classifies it as moderately hard water (Hem, 1985). Hardness is caused primarily by the presence of calcium and magnesium. According to Lillie and Mason (1983), relatively low concentrations of calcium, magnesium, and alkalinity characterize lakes in this region. They found that for 189 lakes sampled in this region, average concentrations of calcium, magnesium, and alkalinity were 10,5 , and $37 \mathrm{mg} / \mathrm{L}$, respectively. During this study, concentrations of calcium, magnesium, and alkalinity in Mercer Lake were 26, 6.5, and $82 \mathrm{mg} / \mathrm{L}$, respectively.

Specific conductance throughout the lake during spring and fall overturns and near the surface during other periods was about $160-220 \mu \mathrm{S} / \mathrm{cm}$, but it increased to greater than $300 \mu \mathrm{S} / \mathrm{cm}$ near the bottom when the deep areas were anaerobic. The $\mathrm{pH}$ in the upper part of the lake typically increased from about 7.5 standard units, in early summer, to about 8.0-8.5 in mid-to-late summer.

The chloride concentration during spring overturn was $12.6 \mathrm{mg} / \mathrm{L}$. The median concentration of chloride in lakes in this area reported by Lillie and Mason (1983) was $2 \mathrm{mg} / \mathrm{L}$. Concentrations of chloride are indicators of urban development in the watershed and road salting in the winter; however, concentrations of chloride in Mercer Lake are still very low when compared to lakes in southeastern Wisconsin lakes. According to U.S. Environmental Protection Agency (1988) water-quality criteria, freshwater aquatic organisms should not be affected if the 4-day average concentration of dissolved chloride remains less than $230 \mathrm{mg} / \mathrm{L}$.

Phosphorus and nitrogen are essential nutrients for plant growth and are the nutrients that usually limit algal growth in most lakes. Elevated nutrient concentrations can cause high algal populations or "blooms"; therefore, high nutrient inputs can be the cause of accelerated eutrophication (that is, accelerated aging and greater lake productivity). Concentrations of near-surface total phosphorus greater than $0.024 \mathrm{mg} / \mathrm{L}$ indicate eutrophic conditions (Carlson, 1977). Near-surface phosphorus concentrations in Mercer Lake demonstrated little seasonality (fig. 7A). During MY 2008 and MY 2009, concentrations ranged from about $0.01 \mathrm{mg} / \mathrm{L}$ to $0.05 \mathrm{mg} / \mathrm{L}$ in midsummer. Concentrations demonstrated no consistent differences between the East and West Basins of the lake. The average near-surface summer (May-September) phosphorus concentration during MY 2008-09 was about $0.023 \mathrm{mg} / \mathrm{L}$ (table 5). Therefore, based on total phosphorus concentrations, Mercer Lake would typically be classified as on the border between mesotrophic and eutrophic.

In MY 2009, there appeared to possibly be a discrepancy between the phosphorus data collected by the USGS and the Citizen Monitoring Program. Therefore, a comparison study was conducted in August 2010 using side-by-side sampling. This comparison study demonstrated little difference (within $0.002 \mathrm{mg} / \mathrm{L}$ ) between the two groups; therefore, the variability in MY 2009 appears to be real changes in phosphorus concentrations in the lake. 

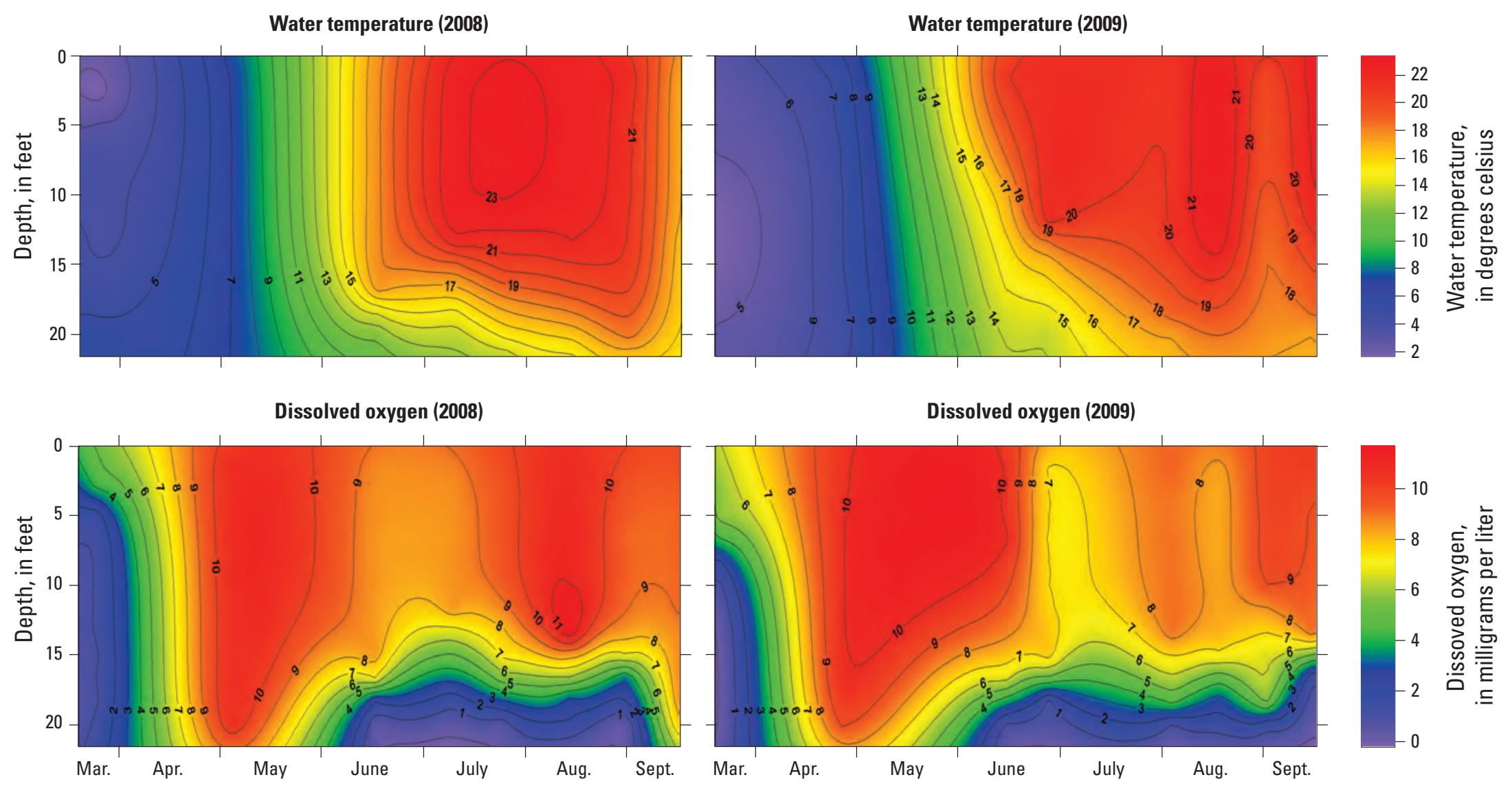

Figure 5. Temperature and dissolved oxygen distribution during open water periods of monitoring years 2008-09, collected at the Deep Hole site in the East Basin of Mercer Lake, Iron County, Wis. 


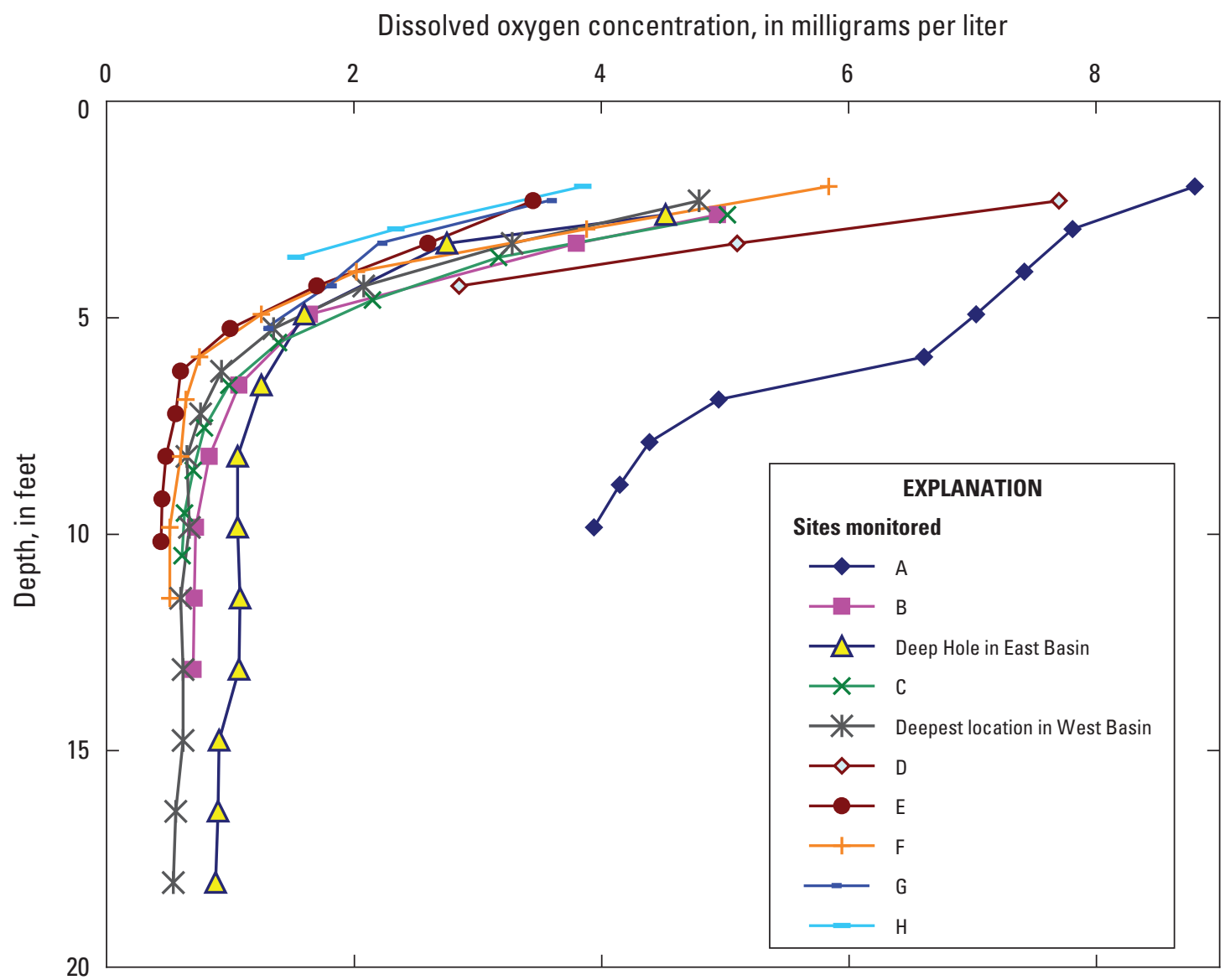

Figure 6. Dissolved oxygen concentrations measured throughout Mercer Lake, Iron County, Wis., on March 26, 2008. Site locations are illustrated in figure 2.

Figure 7 (right). Near-surface $A$, total phosphorus concentrations, $B$, chlorophyll a concentrations, and $C$, Secchi depths in the East and West Basins of Mercer Lake, Iron County, Wis., during monitoring years 2008-09. 
$\boldsymbol{A}$

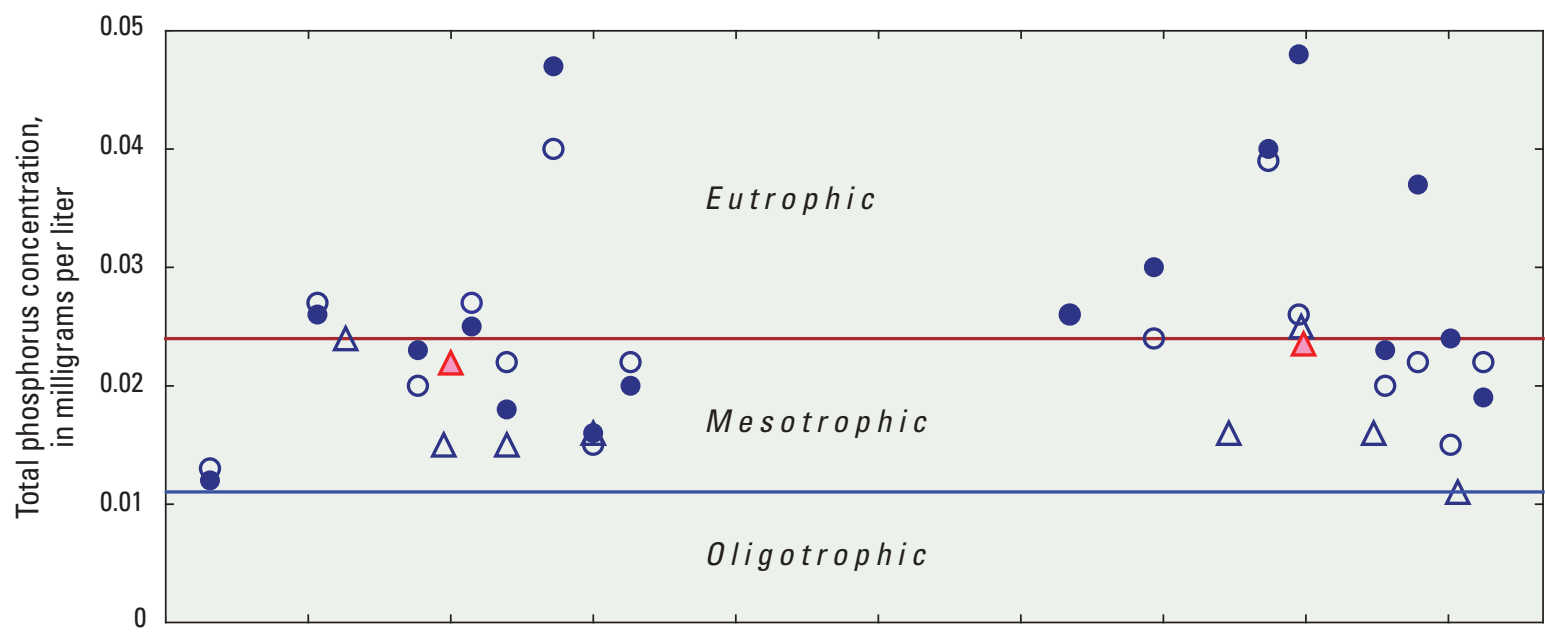

B

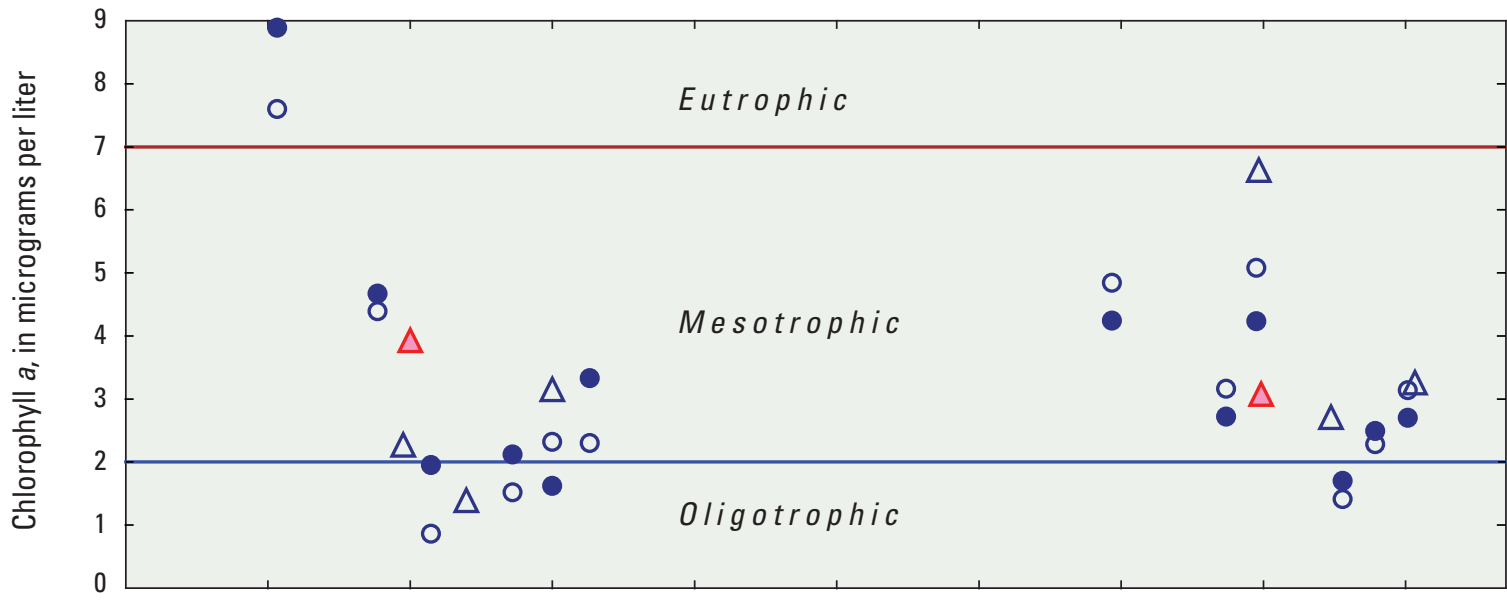

C

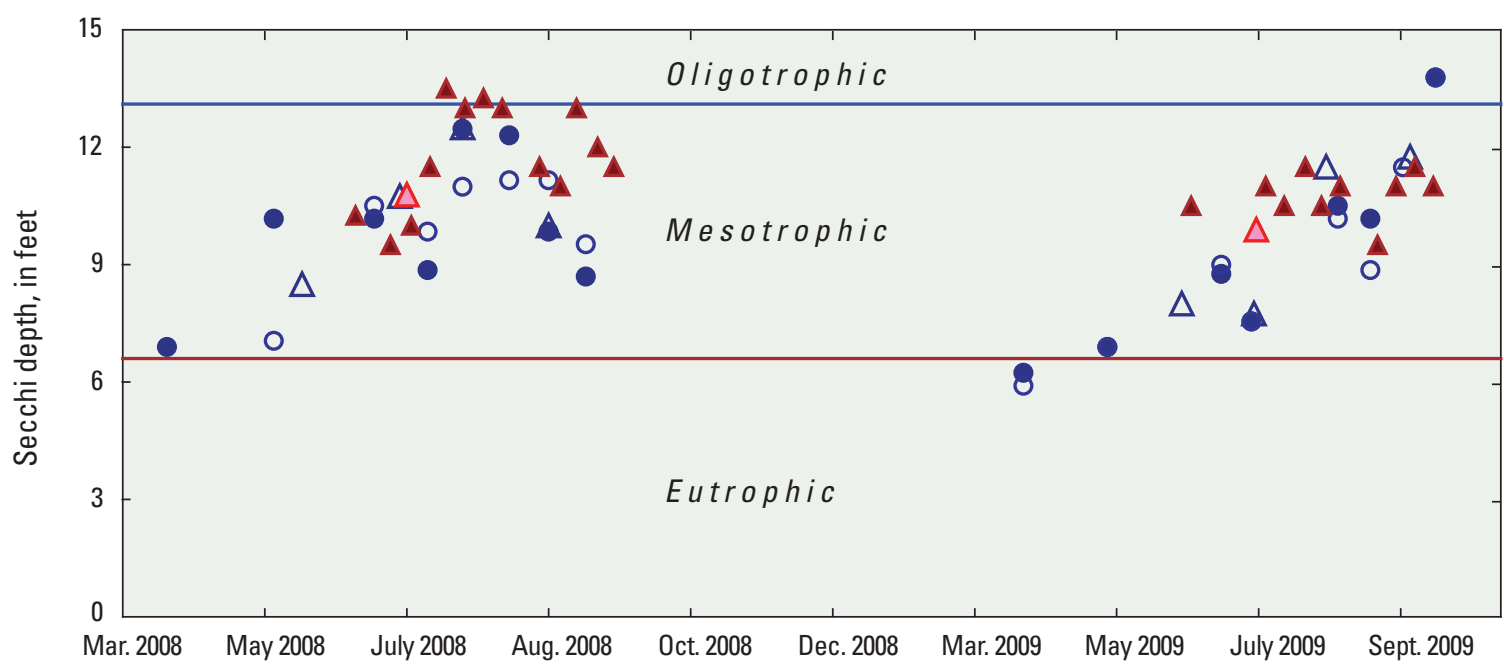

\section{EXPLANATION}

- USGS - East Basin

$\Delta$ Citizen monitoring - East Basin

- USGS - West Basin

$\triangle$ Summer average

Citizen monitoring - West Basin

Eutrophic threshold

Mesotrophic threshold 
Table 5. Near-surface, summer-average (May-September) total phosphorus, chlorophyll $a$, and Secchi depths for the East and West Basins, and trophic state index values based on data from the East Basin of Mercer Lake, Iron County, Wis. from 1973 to 2011.

$[\mathrm{mg} / \mathrm{L}$, milligrams per liter; $\mu \mathrm{g} / \mathrm{L}$, micrograms per liter; ft, feet; - , not available or no data]

\begin{tabular}{|c|c|c|c|c|c|c|c|c|c|}
\hline \multirow[b]{2}{*}{ Year } & \multicolumn{3}{|c|}{ East Basin } & \multicolumn{3}{|c|}{ West Basin } & \multicolumn{3}{|c|}{ Trophic state index values (East Basin) ${ }^{1}$} \\
\hline & $\begin{array}{c}\text { Total } \\
\text { phosphorus } \\
\text { (mg/L) }\end{array}$ & $\begin{array}{l}\text { Chlorophyll a } \\
\text { ( } \mu \mathrm{g} / \mathrm{L})\end{array}$ & $\begin{array}{c}\text { Secchi depth } \\
\text { (ft) }\end{array}$ & $\begin{array}{c}\text { Total } \\
\text { phosphorus } \\
\text { (mg/L) }\end{array}$ & $\begin{array}{c}\text { Chlorophyll a } \\
(\mu \mathrm{g} / \mathrm{L})\end{array}$ & $\begin{array}{c}\text { Secchi depth } \\
\text { (ft) }\end{array}$ & Phosphorus & Chlorophyll a & Secchi depth \\
\hline 1973 & 0.040 & - & 7.5 & - & - & - & 57.3 & - & 48.1 \\
\hline 1974 & 0.030 & - & 5.7 & - & - & - & 52.3 & - & 52.1 \\
\hline 1975 & 0.020 & - & 6.5 & - & - & - & 47.3 & - & 50.1 \\
\hline 1976 & 0.030 & - & 8.0 & - & - & - & 53.2 & - & 47.1 \\
\hline 1979 & 0.027 & 5.5 & 10.0 & - & - & - & 51.7 & 47.7 & 43.9 \\
\hline 2000 & 0.015 & - & - & - & - & - & 43.2 & - & - \\
\hline 2001 & - & - & 20.0 & - & - & - & - & - & 33.9 \\
\hline 2002 & 0.018 & 4.0 & 10.5 & - & - & - & 45.8 & 45.2 & 45.9 \\
\hline 2004 & - & - & 7.3 & - & - & 7.3 & - & - & 48.6 \\
\hline 2005 & - & - & 10.6 & - & - & 10.6 & - & - & 43.4 \\
\hline 2006 & 0.017 & 3.9 & 10.9 & - & - & - & 45.0 & 44.3 & 42.9 \\
\hline 2007 & 0.017 & 2.1 & 11.1 & - & - & 11.4 & 44.4 & 40.2 & 42.6 \\
\hline 2008 & 0.022 & 3.9 & 10.1 & 0.024 & 3.4 & 10.4 & 48.0 & 43.7 & 43.9 \\
\hline 2009 & 0.024 & 3.1 & 10.0 & 0.024 & 3.0 & 10.5 & 48.4 & 42.9 & 44.1 \\
\hline 2010 & 0.018 & 2.6 & 12.4 & - & - & - & 44.8 & 41.7 & 40.9 \\
\hline 2011 & 0.019 & 3.2 & - & - & - & 10.1 & 46.7 & 43.3 & 43.9 \\
\hline $\begin{array}{l}\text { Average } \\
\quad 2006-10\end{array}$ & 0.019 & 3.1 & 10.7 & - & - & - & 46.1 & 42.6 & 42.9 \\
\hline $\begin{array}{l}\text { Average } \\
2008-09\end{array}$ & 0.023 & 3.5 & 10.1 & 0.024 & 3.2 & 10.4 & 48.2 & 43.3 & 44.0 \\
\hline
\end{tabular}

\footnotetext{
'Trophic state index values for 2004, 2005, 2007, and 2011 include Secchi data from the West Basin.
} 


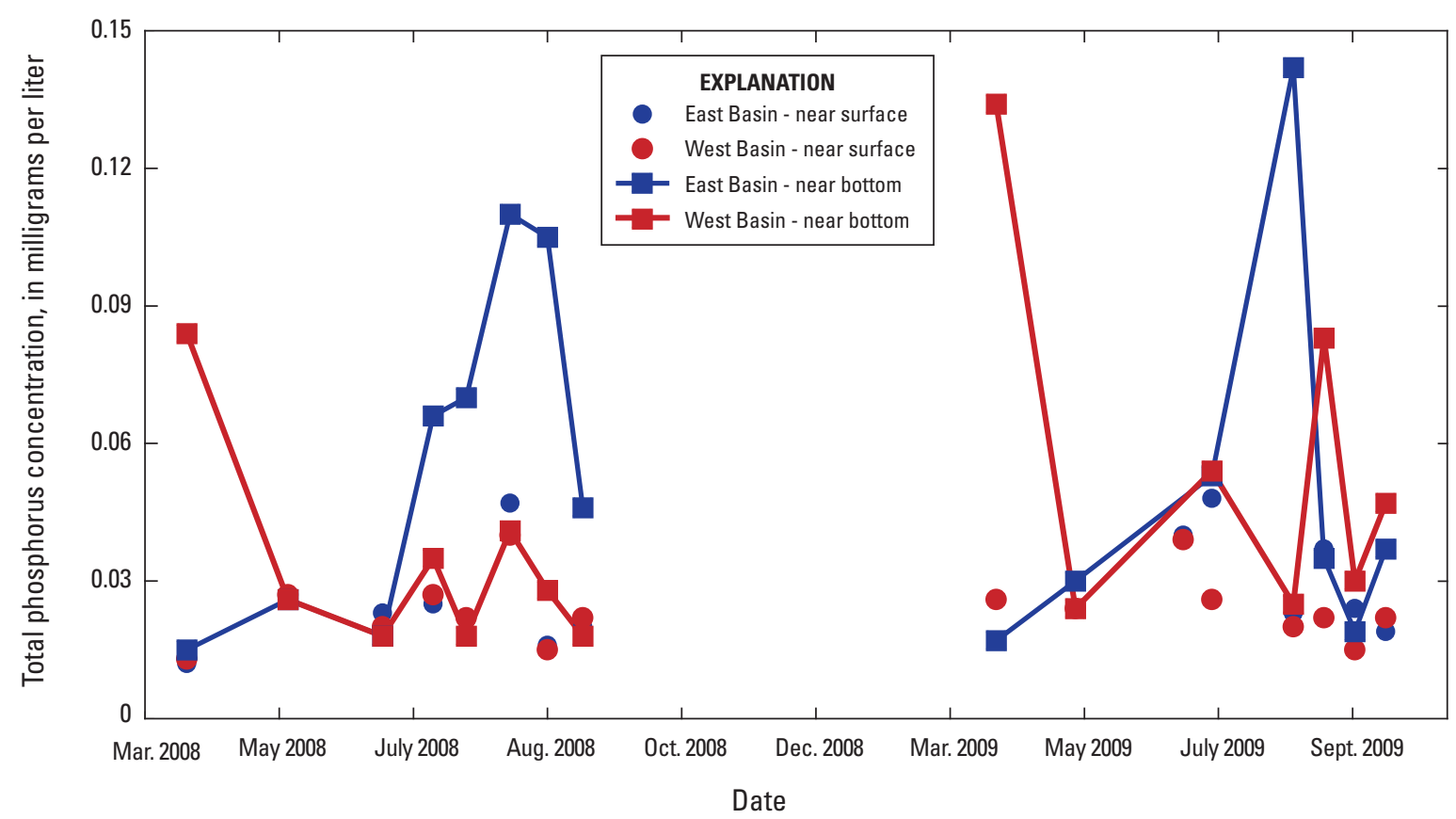

Figure 8. Near-surface and near-bottom total phosphorus concentrations in the East and West Basins of Mercer Lake, Iron County, Wis., during monitoring years 2008-09.

Near-bottom total phosphorus concentrations were similar to those near the surface during unstratified periods; however, phosphorus concentrations increased relatively quickly after the near-bottom water became anoxic in winter in the West Basin and in summer in the deeper East Basin (fig. 8). Maximum concentrations in the two basins reached approximately $0.14 \mathrm{mg} / \mathrm{L}$. The higher concentrations in summer in the East Basin than in the West Basin may have resulted from this basin being deeper, which resulted in longer and more extensive stratification and anoxia. During summer in the West Basin, phosphorus concentrations began to occasionally increase, but then decreased, presumably with mixing in this shallower basin. It is unclear why phosphorus concentrations did not increase in the East Basin during winter stratification; both basins had similar hypoxic conditions below about $13 \mathrm{ft}$.

Since 1973, near-surface total phosphorus concentrations have ranged from $0.011 \mathrm{mg} / \mathrm{L}$ to $0.048 \mathrm{mg} / \mathrm{L}$, and the low and high concentrations were both measured in 2009 (fig. 9A). From the 1970 s to the 2011 , summer-average concentrations have ranged from $0.015 \mathrm{mg} / \mathrm{L}$ in 2000 to $0.040 \mathrm{mg} / \mathrm{L}$ in 1973 . Although summer-average concentrations have been variable, there appears to be a decrease in total phosphorus concentrations, which is consistent with that expected with the discontinuation of discharge of sewage effluent from the town of Mercer.

During spring of 2008 and 2009, near-surface total nitrogen concentrations (computed as the sum of Kjeldahl nitrogen and dissolved nitrite plus nitrate) ranged from 0.55 to $0.61 \mathrm{mg} / \mathrm{L}$; Kjeldahl nitrogen represented more than
95 percent of the total nitrogen. These values are similar to those measured in the late $1970 \mathrm{~s}$ and $2000 \mathrm{~s}(0.43$ to $0.96 \mathrm{mg} / \mathrm{L})$; the highest and lowest concentrations were both measured in 1973.

The ratio of the near-surface concentrations of total nitrogen to total phosphorus (N:P ratio) is often used to determine the potential limiting nutrient for productivity in a lake. The specific value of this ratio that determines which nutrient potentially is limiting differs under different ambient conditions, such as water temperature, light intensity, and nutrient deficiencies (Correll, 1998); however, a ratio greater than about $16: 1$ by weight usually indicates that phosphorus should be the potentially limiting nutrient. The N:P ratios for 1970 s data ranged from $7: 1$ to $28: 1$, with an average ratio of $18: 1$. This indicates that phosphorus should have been the potentially limiting nutrient, but nitrogen does appear to occasionally limit productivity. Since 2002, the N:P ratios have ranged from 20:1 to $24: 1$, with an average of $22: 1$. These ratios indicate that phosphorus typically should be the nutrient typically limiting productivity in the lake.

Further decreases in phosphorus concentrations should not only increase the N:P ratio, but also favor the growth of green algae over the growth of blue-green algae. Blue-green algae usually are not limited by nitrogen, because they can fix nitrogen from the atmosphere. Blue-green algae are the least desirable type of algae, because they commonly form extensive blooms or scums on the water surface, are potentially toxic, and are usually the least preferred food by grazing zooplankton. Therefore, phosphorus should be the nutrient of concern when considering management efforts to improve or prevent degradation of the water quality of Mercer Lake. 
$\boldsymbol{A}$

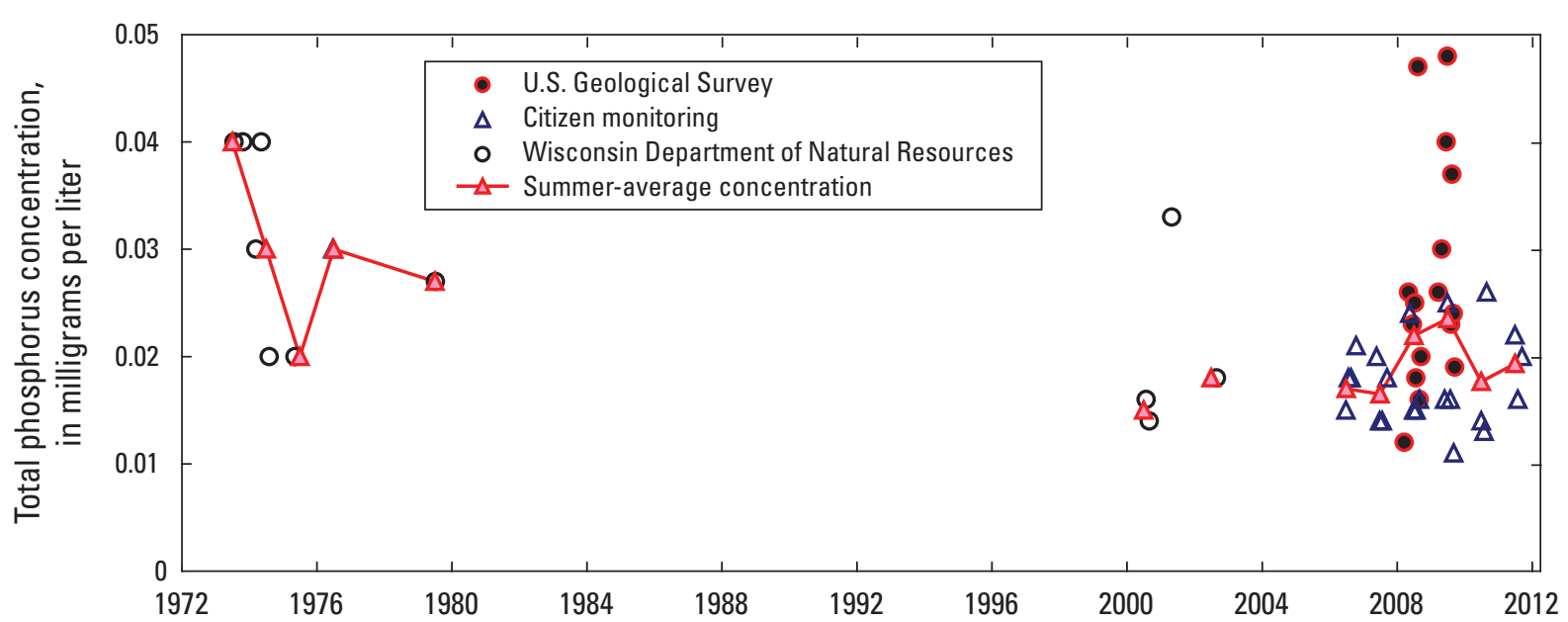

$\boldsymbol{B}$

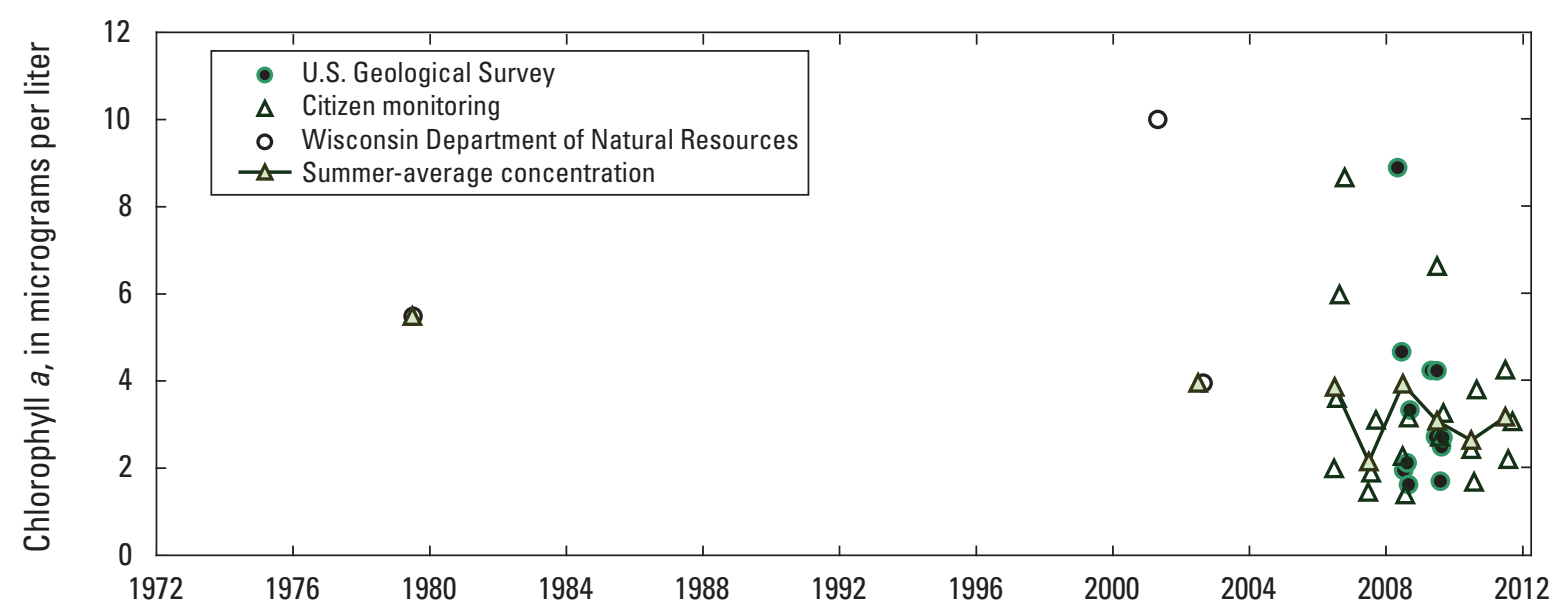

C

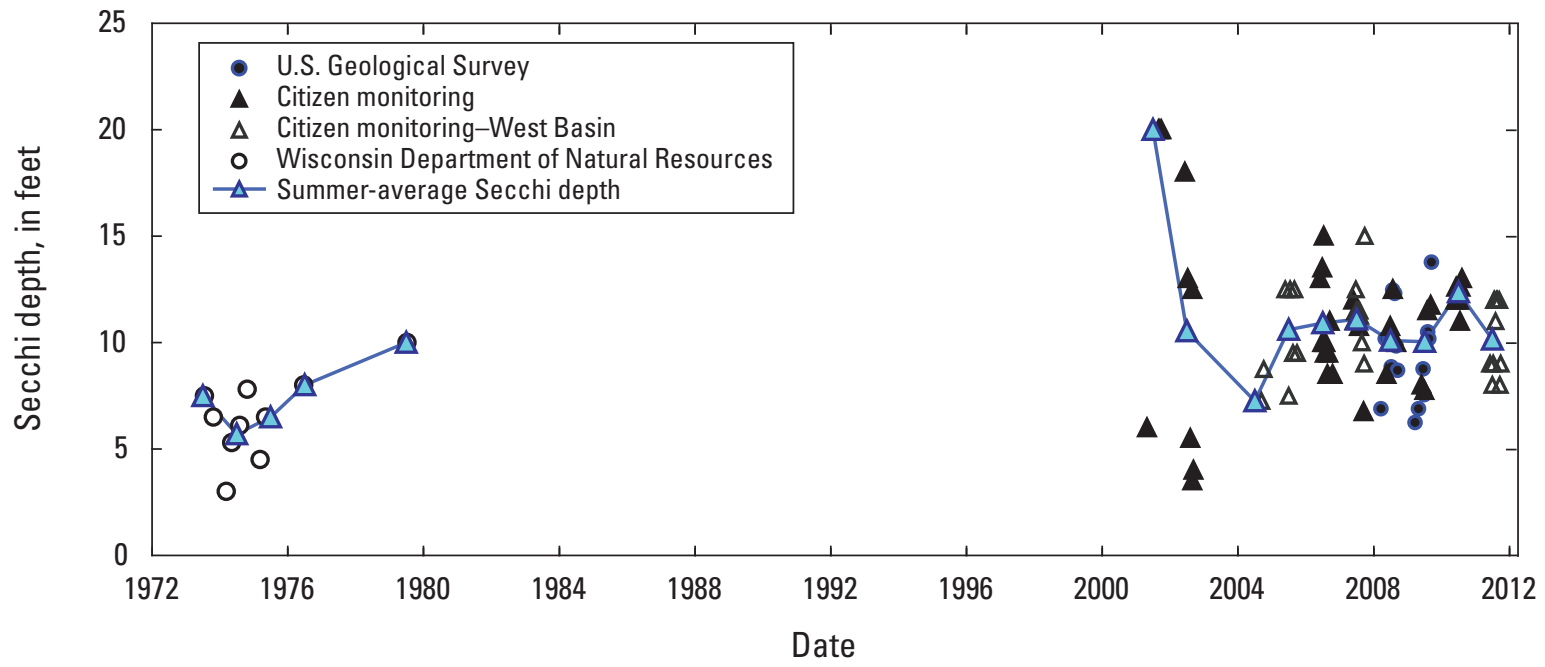

Figure 9. Near-surface $A$, total phosphorus concentrations, $B$, chlorophyll a concentrations, and $C$, Secchi depths in the East Basin of Mercer Lake, Iron County, Wis., from 1973 to 2011. 


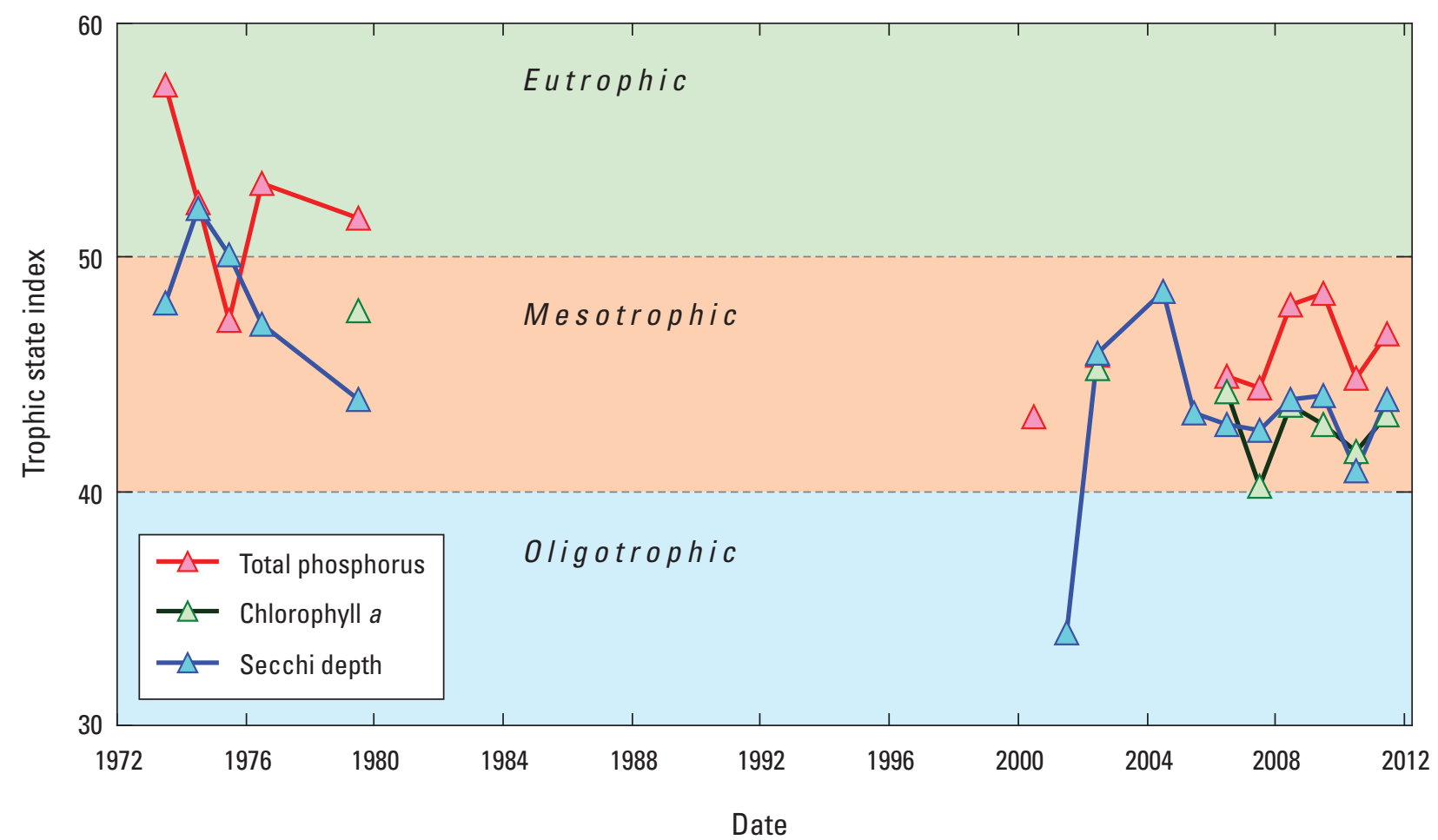

Figure 10. Trophic state index values based on water quality measured in the East Basin of Mercer Lake, Wis., from 1973 to 2011.

Chlorophyll $a$ is a photosynthetic pigment found in algae and other green plants. Its concentration is commonly used as a measure of the density of the algal population in a lake. Average concentrations between about 2 and $7 \mu \mathrm{g} / \mathrm{L}$ indicate mesotrophic conditions, and average concentrations greater than $7 \mu \mathrm{g} / \mathrm{L}$ indicate eutrophic conditions (Carlson, 1977). During MY 2008-09, concentrations ranged from 0.9 to $9 \mu \mathrm{g} / \mathrm{L}$ (fig. $7 B$ ). No consistent differences were observed between the East and West Basins of the lake. Concentrations were generally highest in spring and early summer, lowest in midsummer, and then increased slightly in late summer. The average near-surface summer chlorophyll $a$ concentrations during MY 2008-09 was about $3.4 \mu \mathrm{g} / \mathrm{L}$ (table 5). Therefore, based on chlorophyll $a$ concentrations, Mercer Lake would typically be classified as mesotrophic.

Since 1979, chlorophyll $a$ concentrations ranged from $1.39 \mu \mathrm{g} / \mathrm{L}$ to $10 \mu \mathrm{g} / \mathrm{L}$ (fig. $9 B$ ). The only chlorophyll $a$ measurement prior to 2001 was $5.5 \mu \mathrm{g} / \mathrm{L}$, measured on July 9, 1979. Since 2001, summer-average concentrations have ranged from 2.1 to $4.0 \mu \mathrm{g} / \mathrm{L}$. Based on these data, no consistent long-term change was apparent.

During MY 2008-09, Secchi depths in Mercer Lake ranged from 5.9 to $9 \mathrm{ft}$ under the ice and during early spring to about $12-14 \mathrm{ft}$ in mid-to-late summer (fig. 7 C). Clarity consistently increased as summer progressed. During MY 2008-09, the average Secchi depth during summer was about $10 \mathrm{ft}$ (table 5). Since 1973, Secchi depths have ranged from $3 \mathrm{ft}$ in 1974 to $20 \mathrm{ft}$ in 2001 (fig. 9C). Summer-average Secchi depths have ranged from $5.7 \mathrm{ft}$ in 1974 to $20 \mathrm{ft}$ in 2001 (Secchi depths were only measured in late summer in 2001) (table 5). Secchi depths between 6.6 and $13.1 \mathrm{ft}$ indicate mesotrophic conditions and less than $6.6 \mathrm{ft}$ indicate eutrophic conditions (Carlson, 1977). Therefore, based on Secchi depths, Mercer Lake would typically be classified as mesotrophic. Since 1973, it appears that the water clarity has improved (fig. 9C).

TSI values based on near-surface concentrations of total phosphorus, chlorophyll $a$, and Secchi depth indicate that in MY 2008 and MY 2009 Mercer Lake was typically mesotrophic (fig. 10 and table 5). During almost every sampling, the lake was classified as mesotrophic based on chlorophyll $a$ concentrations and Secchi depths; however, on many occasions the lake was classified as eutrophic based on total phosphorus concentrations greater than $0.024 \mathrm{mg} / \mathrm{L}$. Since 1973, all three TSIs decreased, which indicates that the water quality of the lake has improved. Based on summer-average TSI values for Secchi depth, it would appear the changes were quite variable; however, the large variations in 2001 and 2004 were probably caused by an unusual sampling frequency rather than changes in the lake. In both of these years, Secchi depths were measured only in late August and September. These unusual summer averages demonstrate the importance of a consistent monitoring program when trying to detect changes in water quality. The improvements in water quality from 1980 to after 2000 are consistent with those expected with the discontinuation of discharge of sewage effluent from the town of Mercer. 


\section{Inferred Lake Water Quality from Analyses of Lake Sediment}

Results of analyses of sediment cores extracted from the deep areas of the West Basin of Mercer Lake and the northeast bay of Grand Portage Lake on July 9, 2003, were used to quantify historical sedimentation rates and reconstruct changes in the water quality and the amount of macrophytes in the lakes (Garrison, 2005). The average annual sedimentation rates for Mercer and Grand Portage Lakes were about $0.011 \mathrm{~g} / \mathrm{cm}^{2}$, which are below average for the lakes that have been studied in Wisconsin. The annual sedimentation rate in Mercer Lake was $0.003 \mathrm{~g} / \mathrm{cm}^{2}$ in the early $1800 \mathrm{~s}$, but it steadily increased to about $0.022 \mathrm{~g} / \mathrm{cm}^{2}$ in recent years. Sedimentation rates in Grand Portage Lake also increased since the early 1800 s to about $0.02 \mathrm{~g} / \mathrm{cm}^{2}$ in the $1990 \mathrm{~s}$, but they may have decreased slightly since 1995.

Based on Garrison's analysis of historic diatom assemblages, macrophytes have always been abundant in Mercer Lake (since the 1800s), but low in Grand Portage Lake. The amount of macrophytes in Mercer Lake, however, may have fluctuated through time, whereas those in Grand Portage Lake have remained low. The changes in diatom assemblages were also used to estimate changes in the water clarity (Secchi depth) in Mercer Lake (fig. 11; Garrison, 1995). It was estimated that average Secchi depths in Mercer Lake were about $11.5 \mathrm{ft}$ in the $1800 \mathrm{~s}$, but decreased relatively rapidly around 1900 in response to increases in erosion and nutrient input from development and lumbering in the area. Secchi depths remained relatively steady until the early 1960s, when average Secchi depths rapidly decreased to about $8 \mathrm{ft}$, likely in response to phosphorus input from the sewage plant. Garrison inferred that during this time, the phosphorus concentrations were highest and macrophyte density was lowest in the entire record for Mercer Lake. Since the 1960s, Secchi depths improved but have been quite variable, which suggests that phosphorus concentrations have decreased and the macrophyte density has increased. The increase in macrophyte density could have been caused by improved water clarity (Garrison, 2005) and, possibly, a longer growing season resulting from increases in air temperatures in the region. Anderson and others (1996) demonstrated that lakes in northern Wisconsin had a trend toward earlier ice out dates from 1968 to 1988, which infers that the growing season has increased since 1968. Since around 1900, nutrient concentrations in Grand Portage Lake increased slightly, but they have not changed much since around 1930. Based on changes in the diatom assemblages, water quality in Mercer Lake appears to have been adversely affected by watershed activities, primarily runoff from the town of Mercer and especially inputs from the sewage treatment plant (Garrison, 1995). Improvements inferred in the lake since the 1960s agree with changes measured in lake water quality since 1973 (fig. 9).
Figure 11. Estimated changes in water clarity (Secchi depth) inferred from changes in diatom assemblages in the sediment core collected in Mercer Lake, Iron County, Wis. (after Garrison, 2005).

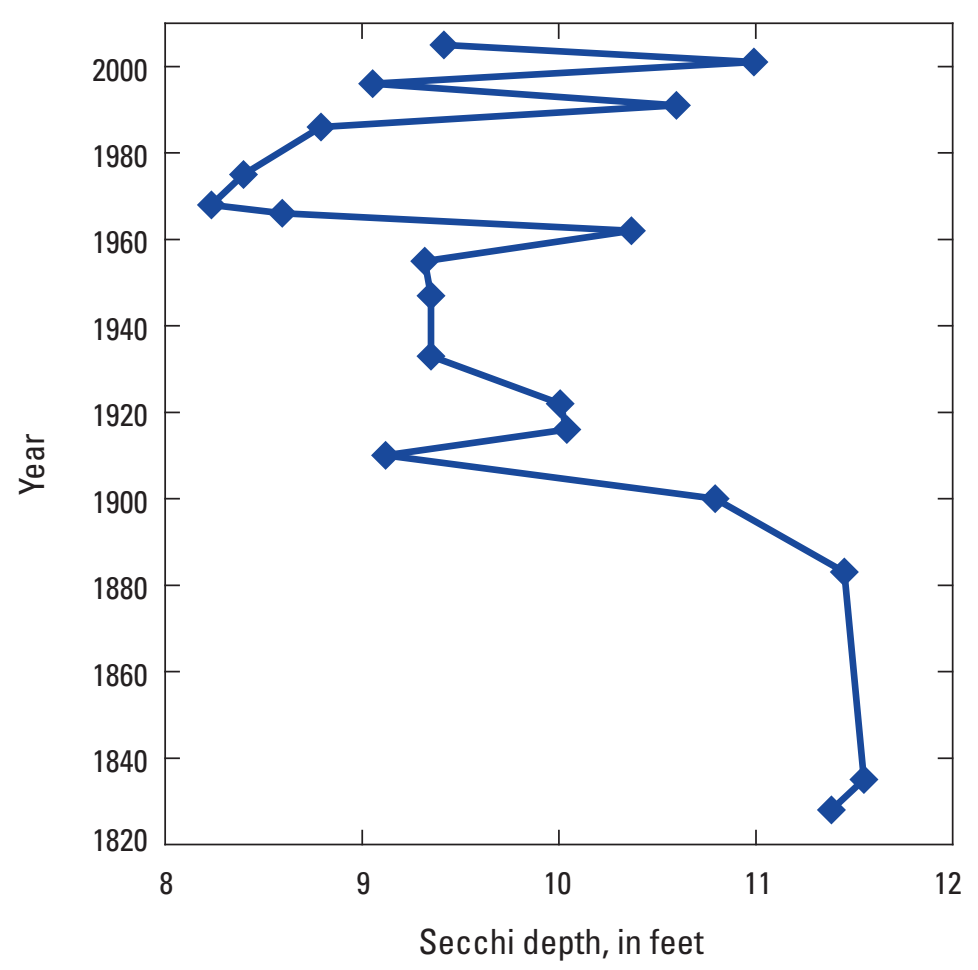




\section{Quality of the Sediments of Mercer Lake}

Many factors may have affected the quality of the sediments in Mercer Lake, especially wastewater discharges from septic systems, the municipal sewage treatment plant, lumber mill and processing operations, and streets and urban areas. Urbanization in the basin increases the likelihood that synthetic organic compounds and trace metals will be transported to the lake. The bottom sediments of a lake provide a historical record of these chemical inputs, because many substances entering the lake eventually are deposited in the sediments in deeper areas. Some of these substances may be released back into the water column with changing environmental conditions.

Many of the priority pollutants identified by the U.S. Environmental Protection Agency (EPA) were among the elements and compounds examined in the sediment analysis for Mercer Lake. Many of these substances have been identified as suspected carcinogens or potentially toxic in other ways to wildlife or humans. Their occurrence in both the water and sediment of aquatic systems depends largely on the characteristics of the watershed and land use within it. Organic content, nutrients, PAHs, disinfectants, detergents, fuel components, combustion products, and some metals (cadmium, chromium, copper, lead, and zinc) could indicate the water was affected by municipal waste input and urban runoff. PAHs, PCBs, and chlorinated hydrocarbons and many metals are byproducts of industrial activities, and their presence in elevated concentrations in natural waters could indicate the lake was affected by industrial discharges. Other chlorinated hydrocarbons and some metals are derived from pesticides and herbicides, and they would most likely occur in aquatic systems that receive agricultural drainage, which should not be much of a factor in the Mercer Lake watershed. In lakes that are remote from point-source discharges, the primary source of many of these substances is atmospheric deposition. In still other systems, weathering or leaching of certain elements from rocks and soils in the watershed can produce unexpectedly high concentrations of certain constituents in receiving waters, even if inputs from industry and agriculture are minimal or nonexistent.

Over the past several years, different entities including several States, EPA, Canadian Provinces, and various researchers have each developed sets of effects-based sediment-quality guidelines (Wisconsin Department of Natural Resources, 2003). The guidelines were developed using empirical approaches that established databases describing a range of effects (such as reduced survival, growth, or reproduction of benthic macroinvertebrate organisms) to a range of concentrations of individual sediment-associated contaminants. The guidelines established two concentration levels based on biological effects - a lower effect concentration at which no or minimal effects are predicted (the threshold effect concentration or TEC) and an upper effect concentration at which adverse effects are highly probable or will frequently be seen (the probable effect concentration or PEC). The TECs are conservative guidelines of possible problems related to sediment chemistry; they represent a lower level of concern than the PECs, and exceedances do not necessarily indicate toxicity. A few environmental factors may increase or decrease the toxicity of some of the metals and organic compounds. Anoxic sediments that occur in the bottom of many lakes may cause some metals to be present in their reduced form that may be more toxic than the TECs and PECs indicate (for example aluminum), whereas, high percentages of organic matter and/or small grains in bottom sediments can reduce the bioavailability and toxicity of some metals (Ankley et al., 1996) and organic compounds.

\section{Organic Content, Phosphorus, and Trace Elements}

The composition of the sediment from the four areas of Mercer Lake and the sediment of Grand Portage Lake (the lake that was thought to be relatively unaffected by human activities and was used as a reference site to represent background conditions) are summarized in tables 6 and 7. In general, concentrations in the deep areas of Mercer Lake were similar to those in Grand Portage Lake for phosphorus and all trace elements (table 6), but concentrations of phosphorus and a few trace elements (aluminum, iron, and manganese) were higher in the deep basins of both lakes than in the shallow bays. Aluminum, iron and manganese are naturally occurring elements abundant in soil and rocks (Hem, 1985). High concentrations of these elements are likely a reflection of the natural iron ore mineralization found in Iron County. Concentrations of lead and zinc were highest in the West Basin of Mercer Lake, likely as a result of effluent from the nearby storm sewer outlet, indicating urban storm water runoff and municipal sources. Concentrations of iron, manganese, cadmium, copper, lead and zinc exceeded their respective TECs, but only concentrations of lead in the West Basin of Mercer Lake were at the PEC.

\section{Synthetic Organic Compounds}

Only a subset of the wastewater compounds for which samples were analyzed as part of this study (Appendix 1) were detected in the sediments of Mercer and Grand Portage Lakes (table 7); however, for most wastewater compounds, concentrations were less than the detection limit and therefore are not listed in table 7. In addition, many of the detected compounds were reported by the laboratory as estimated concentrations because of low concentrations and recovery, precision, blank contamination, or reference standard issues commonly associated with analyzing these compounds. The minimum reporting level (less-than values) for some of the compounds was also relatively high, greater than the TECs, because the sample size was smaller than optimum or had large organic content (for 
Table 6. Phosphorus and trace element concentrations in the bottom sediment of Mercer and Grand Portage Lakes, Iron County, Wis.

[TEC, threshold effect concentration; PEC, probable effects concentration; NA, not available; $<$, less than]

\begin{tabular}{|c|c|c|c|c|c|c|c|c|}
\hline \multirow[b]{2}{*}{ Constituent } & \multirow[b]{2}{*}{$\begin{array}{l}\text { Reporting } \\
\text { level }\end{array}$} & \multicolumn{5}{|c|}{ Station name, site number on figure 2, and station identification number } & \multicolumn{2}{|c|}{ Standards } \\
\hline & & $\begin{array}{c}\text { Mercer Lake, near } \\
\text { Outlet, } \\
\text { s6 } \\
460930090043200 \\
\end{array}$ & $\begin{array}{c}\text { Mercer Lake, } \\
\text { Northwest Bay, } \\
\text { s5 } \\
460950090041300 \\
\end{array}$ & $\begin{array}{c}\text { Mercer Lake, } \\
\text { West Basin, } \\
\text { deepest location, s2 } \\
460945090040600\end{array}$ & $\begin{array}{c}\text { Mercer Lake, } \\
\text { East Basin, } \\
\text { Deep Hole, s1 } \\
460937090033100 \\
\end{array}$ & $\begin{array}{l}\text { Grand Portage Lake, } \\
\text { Northeast Bay } \\
\text { Deep Hole } \\
461030090023800\end{array}$ & TEC $^{1}$ & PEC $^{1}$ \\
\hline \multicolumn{9}{|c|}{ Volatile solids (percent) and phosphorus (milligram per kilogram of sediment) ${ }^{2}$} \\
\hline Volatile solids & 0.1 & 45.2 & 58.1 & 48.4 & 35.0 & 44.3 & NA & NA \\
\hline Total phosphorus & 9.9 & 679 & 720 & 1320 & 885 & 1210 & NA & NA \\
\hline $\begin{array}{l}\text { Phosphate, as phosphorus, } \\
\text { iron and aluminum } \\
\text { bound }\end{array}$ & 5 & 83 & 83 & 399 & 186 & 514 & NA & NA \\
\hline \multicolumn{9}{|c|}{ Trace elements (milligram per kilogram of sediment) $)^{3}$} \\
\hline Aluminum, recoverable & 2.8 & 5400 & 4300 & 8700 & 8800 & 10000 & NA & NA \\
\hline Boron, recoverable & 1.8 & $<3.6$ & $<3.6$ & $<9.0$ & $<9.0$ & $<5.4$ & NA & NA \\
\hline Cadmium, recoverable & 0.001 & 1.3 & 0.83 & 1.6 & 1.6 & 1.7 & 0.99 & 5 \\
\hline Chromium, recoverable & 0.4 & 26 & 19 & 32 & 42 & 36 & 43 & 110 \\
\hline Cobalt, recoverable & 0.001 & 3.5 & 2.2 & 4.9 & 4.9 & 6 & NA & NA \\
\hline Copper, recoverable & 2 & 33 & 25 & 42 & 32 & 44 & 32 & 150 \\
\hline Iron, total digestable & 2.1 & 16,000 & 12,000 & 53,000 & 42,000 & 35,000 & 20,000 & 40,000 \\
\hline Lead, recoverable & 0.001 & 64 & 28 & 130 & 85 & 84 & 36 & 130 \\
\hline Manganese, recoverable & 0.3 & 960 & 550 & 640 & 580 & 610 & 460 & 1,100 \\
\hline Mercury, recoverable & 0.0072 & 0.097 & 0.051 & 0.094 & 0.105 & 0.102 & 0.18 & 1.1 \\
\hline Zinc, recoverable & 0.1 & 160 & 74 & 200 & 170 & 160 & 120 & 460 \\
\hline
\end{tabular}

${ }^{1}$ Wisconsin Department of Natural Resources, 2003.

${ }^{2}$ Analyses conducted by the Wisconsin State Laboratory of Hygiene in Madison, Wis.

${ }^{3}$ Analyses conducted by the U.S. Geological Survey National Water Quality Laboratory in Denver, Colo. 
Table 7. Concentrations of wastewater compounds detected in the bottom sediment of Mercer and Grand Portage Lakes, Iron County, Wis.

[Concentrations are reported in microgram per kilogram of sediment except where noted. All analyses, except polychlorinated biphenyls (PCBs), were conducted at the U.S. Geological Survey National Water Quality Laboratory in Denver, Colo. PCBs were analyzed by the Wisconsin State Laboratory of Hygiene in Madison, Wis. TEC, threshold effect concentration; PEC, probable effect concentration; <, less than; E, estimated concentration reported; NA, not available; ND, no data; PCB, polychlorinated biphenyls; PAH, polycyclic aromatic hydrocarbon; CP, combustion product]

\begin{tabular}{|c|c|c|c|c|c|c|c|c|}
\hline \multirow[b]{2}{*}{ Constituent } & \multicolumn{5}{|c|}{ Station name, site number on figure 2 , and station identification number } & \multicolumn{2}{|c|}{ Standard } & \multirow[b]{2}{*}{$\begin{array}{l}\text { Possible uses or sources of the } \\
\text { constituent }{ }^{2}\end{array}$} \\
\hline & $\begin{array}{c}\text { Mercer Lake, } \\
\text { near Outlet, } \\
\text { s6 } \\
460930090043200\end{array}$ & $\begin{array}{c}\text { Mercer Lake, } \\
\text { Northwest Bay, } \\
\text { s5 } \\
460950090041300\end{array}$ & $\begin{array}{c}\text { Mercer Lake, } \\
\text { West Basin, } \\
\text { deepest location, s2 } \\
460945090040600\end{array}$ & $\begin{array}{l}\text { Mercer Lake, } \\
\text { East Basin, } \\
\text { Deep Hole, s1 } \\
460937090033100\end{array}$ & $\begin{array}{c}\text { Grand Portage Lake, } \\
\text { NE Bay } \\
\text { Deep Hole } \\
461030090023800\end{array}$ & TEC $^{1}$ & PEC $^{1}$ & \\
\hline \multicolumn{9}{|c|}{ Indicators of sewage contamination } \\
\hline 3-beta-Coprostanol, solids & $<1,700$ & $<2,800$ & E 740 & E 660 & $<1,800$ & NA & NA & Carnivore fecal indicator. \\
\hline 3-Methyl-1H-indole, solids & 270 & E 210 & E 220 & 250 & 250 & NA & NA & $\begin{array}{l}\text { Fragrance, stench in feces and } \\
\text { coal tar. }\end{array}$ \\
\hline beta-Sitosterol, solids & E 4,500 & E 4,800 & E 5,600 & E 5,000 & E 5,500 & NA & NA & $\begin{array}{l}\text { Sewage indicator-possible plant } \\
\text { sterol. }\end{array}$ \\
\hline beta-Stigmastanol, solids & E 3,500 & E 3,800 & E 5,600 & E 4,400 & E 5,200 & NA & NA & $\begin{array}{l}\text { Sewage indicator-possible plant } \\
\text { sterol. }\end{array}$ \\
\hline $\begin{array}{l}\text { 4-Nonylphenol } \\
\text { diethoxylate,sd }\end{array}$ & E 1,500 & E 1,800 & E 2,300 & E 2,900 & $<3,600$ & NA & NA & $\begin{array}{l}\text { Sewage indicator and detergent } \\
\text { metabolite. }\end{array}$ \\
\hline 4-t-Octylphenol diethoxylate & $<170$ & $<280$ & $<230$ & $<220$ & $<180$ & NA & NA & $\begin{array}{l}\text { Sewage indicator, detergent me- } \\
\text { tabolite, pesticides, and coffee. }\end{array}$ \\
\hline Benzo[a]pyrene, solids & E 30 & $<280$ & E 70 & E 60 & E 30 & 150 & 1,450 & $\begin{array}{l}\text { Regulated } \mathrm{PAH} \text {, used in cancer } \\
\text { research, CP. }\end{array}$ \\
\hline Cholesterol, solids & E 1,200 & E 1,600 & E 2,700 & E 1,900 & E 2,000 & NA & NA & Fecal indicator. \\
\hline Acetophenone, solids & $<520$ & E 700 & $<680$ & $<650$ & $<540$ & NA & NA & $\begin{array}{l}\text { Fragrance in detergent and to- } \\
\text { bacco, flavor in beverages. }\end{array}$ \\
\hline Indole, solids & 2,800 & 2,000 & 4,100 & E 2,200 & 3,000 & NA & NA & $\begin{array}{l}\text { Pesticide inert ingredient, fra- } \\
\text { grance in coffee. }\end{array}$ \\
\hline Naphthalene, solids & E 40 & $<280$ & E 110 & E 90 & E 50 & 176 & 561 & $\begin{array}{l}\text { PAH, pesticide inert ingredient, } \\
\text { moth repellent. }\end{array}$ \\
\hline \multicolumn{9}{|c|}{ Indicators of street and fuel contamination } \\
\hline $\begin{array}{l}\text { 2,6-Dimethylnaphthalene, } \\
\text { solids }\end{array}$ & 200 & E 150 & 510 & 390 & 370 & NA & NA & $\begin{array}{l}\text { Diesel fuel and kerosene (trace in } \\
\text { gasoline). }\end{array}$ \\
\hline 2-Methylnaphthalene, solids & $<170$ & $<280$ & E 40 & $<220$ & $<180$ & 20.2 & 201 & $\begin{array}{l}\text { Gasoline, diesel fuel, or crude oil } \\
\text { ( } 2-5 \text { percent })\end{array}$ \\
\hline Fluoranthene, solids & E 100 & E 50 & 300 & E 190 & E 120 & 423 & 2,230 & $\begin{array}{l}\text { PAH, component of coal tar } \\
\text { and asphalt (only traces in } \\
\text { gasoline). }\end{array}$ \\
\hline Isophorone, solids & E 40 & E 190 & E 60 & E 50 & E 40 & NA & NA & $\begin{array}{l}\text { Solvent for lacquer, plastic, oil, } \\
\text { silicon, resin. }\end{array}$ \\
\hline
\end{tabular}


Table 7. Concentrations of wastewater compounds detected in the bottom sediment of Mercer and Grand Portage Lakes, Iron County, Wis.-Continued

[Concentrations are reported in microgram per kilogram of sediment except where noted. All analyses, except polychlorinated biphenyls (PCBs), were conducted at the U.S. Geological Survey National Water Quality Laboratory in Denver, Colo. PCBs were analyzed by the Wisconsin State Laboratory of Hygiene in Madison, Wis. TEC, threshold effect concentration; PEC, probable effect concentration; <, less than; E, estimated concentration reported; NA, not available; ND, no data; PCB, polychlorinated biphenyls; PAH, polycyclic aromatic hydrocarbon; CP, combustion product]

\begin{tabular}{|c|c|c|c|c|c|c|c|c|}
\hline \multirow[b]{2}{*}{ Constituent } & \multicolumn{5}{|c|}{ Station name, site number on figure 2 , and station identification number } & \multicolumn{2}{|c|}{ Standard } & \multirow[b]{2}{*}{$\begin{array}{l}\text { Possible uses or sources of the } \\
\text { constituent }{ }^{2}\end{array}$} \\
\hline & $\begin{array}{c}\text { Mercer Lake, } \\
\text { near Outlet, } \\
\text { s6 } \\
460930090043200\end{array}$ & $\begin{array}{c}\text { Mercer Lake, } \\
\text { Northwest Bay, } \\
\text { s5 } \\
460950090041300 \\
\end{array}$ & $\begin{array}{c}\text { Mercer Lake, } \\
\text { West Basin, } \\
\text { deepest location, s2 } \\
460945090040600\end{array}$ & $\begin{array}{c}\text { Mercer Lake, } \\
\text { East Basin, } \\
\text { Deep Hole, s1 } \\
\mathbf{4 6 0 9 3 7 0 9 0 0 3 3 1 0 0}\end{array}$ & $\begin{array}{c}\text { Grand Portage Lake, } \\
\text { NE Bay } \\
\text { Deep Hole } \\
461030090023800\end{array}$ & TEC $^{1}$ & PEC $^{1}$ & \\
\hline \multicolumn{9}{|c|}{ Indicators of street and fuel contamination-Continued } \\
\hline Phenanthrene, solids & E 90 & $<280$ & E 210 & E 130 & E 90 & 204 & 1,170 & $\begin{array}{l}\text { PAH, manufacturing explo- } \\
\text { sives, component of tar, } \\
\text { diesel fuel, or crude oil, CP. }\end{array}$ \\
\hline Prometon, solids & $<170$ & $<80$ & $<230$ & $<220$ & $<180$ & NA & NA & $\begin{array}{l}\text { Herbicide (noncrop only), ap- } \\
\text { plied prior to blacktop. }\end{array}$ \\
\hline Pyrene, solids & E 80 & E 40 & 230 & E 160 & E 90 & 195 & 1,520 & $\begin{array}{l}\text { PAH, component of coal tar } \\
\text { and asphalt (only traces in } \\
\text { gasoline or diesel fuel), CP. }\end{array}$ \\
\hline \multicolumn{9}{|c|}{ Indicators of lumber processing contamination } \\
\hline Anthracene, solids & $<170$ & $<280$ & E 30 & E 30 & E 10 & 57 & 845 & $\begin{array}{l}\text { PAH, wood preservative, com- } \\
\text { ponent of tar, diesel, or crude } \\
\text { oil, CP. }\end{array}$ \\
\hline p-Cresol, solids & E 620 & E 570 & E 530 & 3,300 & 1,100 & ND & ND & Wood preservative. \\
\hline \multicolumn{9}{|c|}{ Indicators of general industrial contamination } \\
\hline Phenol, solids & E 3,300 & E 7,600 & $<440$ & E 730 & E 680 & 4,200 & 12,000 & $\begin{array}{l}\text { Disinfectant, manufacturing } \\
\text { several products, plywood, } \\
\text { fuel additives, leachate. }\end{array}$ \\
\hline $\begin{array}{l}\text { Total polychlorinated biphe- } \\
\text { nyls (PCBs in milligram } \\
\text { per gram of sediment) }\end{array}$ & 0.024 & ND & ND & 0.024 & ND & 60 & 676 & Many industrial sources. \\
\hline
\end{tabular}

per gram of sediment)

${ }^{1}$ Wisconsin Department of Natural Resources, 2003.

${ }^{2}$ Uses obtained from J.R. Ward, U.S. Geological Survey,. written commun., February 28, 2006.

${ }^{3}$ Reporting limit is 0.024 milligram per kilogram of sediment. 
example, anthracene) that made comparisons uncertain. Most guidelines (TECs and PECs) are usually expressed on a dry weight basis normalized at 1 percent total organic carbon to put the results on a common basis; however, this normalization process could not be performed because the information was not available. The high organic content (35 to 58 percent volatile solids) of the sediments in both lakes has a significant effect on decreasing the potential toxicity of some of the organic compounds to values below the TEC or PEC. Therefore, the toxicity for several compounds (based on the comparisons with the TECs and PECs in table 7) appears worse than what it actually would be if the data were normalized to the percent total organic carbon in the sample.

The sediments of both lakes contained many constituents that are indicative of the past activities in their watersheds. In table 7, these constituents are divided into indicators of sewage, street and fuel, lumber industry, and general industrial contamination. Concentrations of most of the indicators of sewage contamination were as high in Grand Portage Lake as they were in Mercer Lake, except acetophenone, which was relatively high in the northwest bay of Mercer Lake. Acetophenone is used in detergents and as a flavor in beverages. Concentrations of many of the indicators of street runoff and fuels were higher in Mercer Lake than in Grand Portage Lake. Concentrations of the PAHs phenanthrene and pyrene, components of coal tar and oil, and 2-methylnaphthalene, a fuel component, were highest in sediment of the West Basin of Mercer Lake. Concentrations of 2-methylnaphthalene, phenanthrene, and pyrene were near or slightly exceeded the TECs at one or more sites in Mercer Lake. Concentrations of two indicators of lumber industry contamination were found in both lakes: anthracene and p-cresol. The concentration of p-cresol, a wood preservative without recommended guidelines, was highest at Deep Hole in the East Basin of Mercer Lake. Two indicators of general industrial contamination, phenol and PCBs, were found in the sediments of both lakes. Phenol, which is used in many kinds of manufacturing, was found in relatively high concentrations (near or just above the TEC) in the northwest bay and near the Mercer Lake Outlet. Total PCBs were found at the detection limit of $0.024 \mathrm{mg} / \mathrm{kg}$ in the Deep Hole of East Basin of Mercer Lake and near the lake outlet and were not of concern as were concentrations of all individual alochlors, which were below the detection limit. None of these compounds that were detected in the sediments of the lakes are known or suspected to have endocrine-disrupting potential.

The results of the analysis of the bottom sediments of Mercer and Grand Portage Lakes indicate that industrial and municipal effluents and runoff from the watershed have produced slightly elevated concentrations of a few elements and compounds in the sediments. Concentrations of metals and organic compounds in sediments of the northwest bay and near the lake outlet were not markedly different from those in other areas of the lake, as would be expected if they had been affected by discharges from the old wastewater treatment plant.The findings for the synthetic organic chemicals are consistent with the land use in the Mercer Lake watershed.
The low concentrations of PAHs and PCBs correspond to the relative absence of industries that would release these compounds in the watershed, unlike findings from more urban areas like Milwaukee (Thomas and others, 2007). Similar to that found in this study, Fitzpatrick and Peppler (2003) found elevated concentrations of pentachlorophenol, p-cresol, and other organic compounds in sediments of an abandoned sawmill pond in northern Wisconsin. Although the concentrations of several potentially toxic elements and compounds were found to slightly exceed their published TEC guidelines, they were generally well below PECs and of low concern. The actual effects of these concentrations on organisms are complicated by many interacting environmental factors and the actual effects are uncertain.

\section{Hydrology and Water Budget}

Because the productivity in Mercer Lake is limited by phosphorus or possibly co-limited by phosphorus and nitrogen (based on N:P ratios) and because decreases in phosphorus concentrations should favor production of green algae over blue-green algae, decreases in the input of phosphorus should reduce phosphorus concentrations in the lake and thus improve water quality. Therefore, it is important to understand the origins of the phosphorus reaching the lake. Almost all of the phosphorus entering the lake is transported by water inputs; therefore, to quantify phosphorus inputs, it is necessary to first quantify the water inputs. Water budgets for the lake were quantified for each of the two monitoring years, MY 2008 and MY 2009.

The hydrology of the lake can be described in terms of components of its water budget. The water budget for a period of interest may be represented as follows:

$$
\Delta S=\left(P+S W_{I n}+G W_{I n}\right)-\left(E+S W_{\text {Out }}+G W_{\text {Out }}\right)
$$

where $\Delta S$ is change in the volume of water stored in the lake and is equal to the sum of the volumes of water entering the lake minus the sum of the volumes leaving the lake. Water enters the lake as precipitation $(P)$, surface-water inflow $\left(S W_{I n}\right)$, and groundwater inflow $\left(G W_{I n}\right)$. Water leaves the lake through evaporation $(E)$, surface-water outflow $\left(S W_{\text {Out }}\right)$, and groundwater outflow $\left(G W_{\text {Out }}\right)$. Each term of the water budget was estimated for MY 2008-09 on a daily basis.

\section{Change in Storage}

Changes in the volume of the lake were determined from water elevations measured continuously at the lake-stage gage on the south shore of the West Basin of the lake (fig. 2). In MY 2008, water levels fluctuated from $1584.4 \mathrm{ft}$ in May to $1583.6 \mathrm{ft}$ in October, and in MY 2009, water levels fluctuated from $1584.1 \mathrm{ft}$ in November to $1583.5 \mathrm{ft}$ in July (U.S. Geological Survey, 2009-10). For MY 2008, the net change in lake 
level from the beginning to end of the period was $-0.14 \mathrm{ft}$, representing a loss in storage of 23 acre-ft (table 8). For MY 2009 , there was a slight gain in stage of $0.04 \mathrm{ft}$, representing a gain in storage of 6 acre-ft.

\section{Precipitation}

During the 2-year study period, daily precipitation was measured with a recording gage at the main inlet site on the Little Turtle River during nonfreezing periods, and it was estimated from the average of that measured in the communities of Butternut (24 mi southwest of the lake), Upson (22 mi northwest), and Manitowish Waters (8 mi east) during freezing periods. Data from the nearby weather stations were obtained from the National Weather Service National Climatic Data Center (2007-09). Precipitation on the lake surface during MY 2008 was 25.93 in. (399 acre-ft), and during MY 2009 was 21.12 in. (325 acre-ft). Precipitation was 81.5 percent of the long-term average (1971-2000) in 2008 and 66.4 percent in 2009, reflecting an extended dry period in the region. Monthly precipitation during each study year is compared to the 1971-2000 average monthly precipitation in figure 12 . In MY 2008, precipitation totals for May through September were below average. In MY 2009, only December and October totals were above the long-term average, and all other months were well below average.

\section{Evaporation}

The rate of evaporation from the lake surface was assumed to be similar to the average monthly rates estimated for Minocqua Lake (26.5 mi southeast of Mercer Lake) during 2006-07 by Garn and others (2010). During 2006-07, Minocqua Lake also experienced very dry conditions and received about 85 percent of the long-term average precipitation. It was assumed that evaporation from the lake surface was zero during periods of ice cover and that the lake was ice covered from December through March. Annual evaporation was estimated to be 23.93 in. (368 acre-ft; table 8 ).

\section{Gaged Surface-Water Inflows}

Daily inflow from the Little Turtle River, the main tributary to the lake, was measured at the gaging station installed at Garnet Street (fig. 2). The annual average flow at this site was $5.20 \mathrm{ft}^{3} / \mathrm{s}\left(3,770\right.$ acre-ft) in MY 2008 and $4.35 \mathrm{ft}^{3} / \mathrm{s}$ (3,150 acre-ft) in MY 2009 (table 8, fig. 13A). Annual flows in the Little Turtle River and other rivers in the region reflected the very dry conditions in north-central Wisconsin during both monitoring years. In 2009, the extremely dry summer prompted the Governor to declare counties in northern Wisconsin in a state of emergency because of drought conditions. In MY 2008, runoff at nearby long-term USGS gaging

Table 8. Summary of water-budget components for Mercer Lake, Iron County, Wis., during monitoring years 2008-09 and during typical hydrologic conditions.

\begin{tabular}{|c|c|c|c|c|c|c|c|c|}
\hline \multirow{2}{*}{ Typical conditions } & \multicolumn{2}{|c|}{ MY 2008} & \multicolumn{2}{|c|}{ MY 2009} & \multicolumn{2}{|c|}{ 2-year average } & \multicolumn{2}{|c|}{ Typical conditions } \\
\hline & $\begin{array}{l}\text { Volume } \\
\text { (acre-ft) }\end{array}$ & Percent & $\begin{array}{l}\text { Volume } \\
\text { (acre-ft) }\end{array}$ & Percent & $\begin{array}{l}\text { Volume } \\
\text { (acre-ft) }\end{array}$ & Percent & $\begin{array}{l}\text { Volume } \\
\text { (acre-ft) }\end{array}$ & Percent \\
\hline \multicolumn{9}{|c|}{ Inputs to lake } \\
\hline Precipitation & 399 & 7.0 & 325 & 7.0 & 362 & 7.0 & 489 & 6.8 \\
\hline Little Turtle Inlet & 3,770 & 66.4 & 3,150 & 67.3 & 3,460 & 66.8 & 4,680 & 65.4 \\
\hline Tahoe Inlet & 248 & 4.4 & 232 & 5.0 & 240 & 4.6 & 324 & 4.5 \\
\hline Storm drain & 22 & 0.4 & 21 & 0.5 & 22 & 0.4 & 29 & 0.4 \\
\hline Groundwater & 878 & 15.5 & 876 & 18.7 & 877 & 16.9 & 1,190 & 16.6 \\
\hline Ungaged area & 359 & 6.3 & 72 & 1.5 & 216 & 4.2 & 441 & 6.2 \\
\hline Total input & 5,680 & 100.0 & 4,680 & 100.0 & 5,180 & 100.0 & 7,150 & 100.0 \\
\hline \multicolumn{9}{|c|}{ Outputs from lake } \\
\hline Evaporation & 368 & 6.5 & 368 & 7.9 & 368 & 7.1 & 403 & 5.6 \\
\hline Little Turtle Outlet & 5,330 & 93.5 & 4,300 & 92.1 & 4,820 & 92.9 & 6,750 & 94.4 \\
\hline Groundwater & 0 & 0.0 & 0 & 0.0 & 0 & 0.0 & 0 & 0.0 \\
\hline Total output & 5,700 & 100.0 & 4,670 & 100.0 & 5,190 & 100.0 & 7,150 & 100.0 \\
\hline \multicolumn{9}{|c|}{ Change in storage (acre-ft and percent of total input) } \\
\hline Change in storage & -23 & -0.4 & 6 & 0.1 & -9 & -0.2 & $\mathbf{0}$ & 0.0 \\
\hline
\end{tabular}




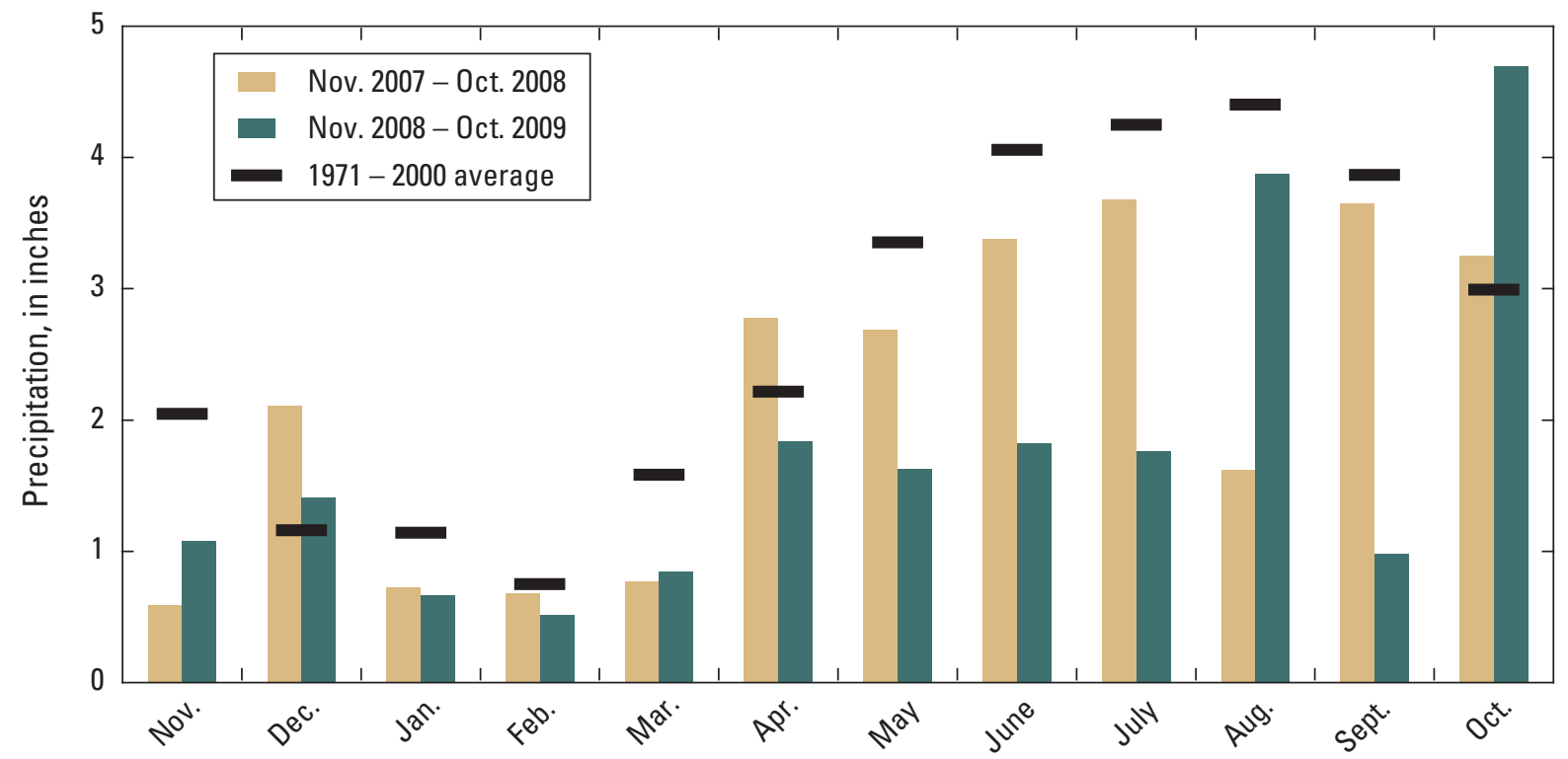

Figure 12. Monthly precipitation at Mercer Lake, Iron County, Wis., during monitoring years 2008-09 relative to long-term average precipitation for the period 1971-2000.

stations was 64 percent of the long-term average annual runoff (1936-2008) at Wisconsin River at Rainbow Lake near Lake Tomahawk, Wis., 65 percent of the average annual runoff (1991-2008) at Bear River near Manitowish Waters, Wis., and 67 percent of the average annual runoff (1991-2008) at the Trout River at Trout Lake near Boulder Junction, Wis. (U.S. Geological Survey, 2009). In MY 2009, runoff was 40 percent of the average annual runoff at the Bear River station, 54 percent at Wisconsin River station, and 57 percent at the Trout River station (U.S. Geological Survey, 2010).

To estimate flow from the Lake Tahoe watershed, intermittent discharge measurements were collected from the stream leaving Lake Tahoe that enters the west side of Mercer Lake. The measured flows at the Tahoe Inlet and the continuously recorded flow at the Little Turtle Inlet were used to develop a regression relation to predict flow at the Tahoe Inlet from the flow at Little Turtle Inlet. The annual average flow at this site was $0.341 \mathrm{ft}^{3} / \mathrm{s}$ (248 acre- $\mathrm{ft}$ ) in MY 2008 and $0.321 \mathrm{ft}^{3} / \mathrm{s}$ (232 acre-ft) in MY 2009 (table 8).

Daily inflow from the storm drain outlet, the other monitored tributary to the lake, was measured at the gaging station near the boat landing (fig. 2). The annual average flow at this site was $0.031 \mathrm{ft}^{3} / \mathrm{s}\left(22\right.$ acre-ft) in MY 2008 and $0.029 \mathrm{ft}^{3} / \mathrm{s}$ (21 acre-ft) in MY 2009 (table 8). This site is characterized by very sudden changes in flow (fig. 13B).

\section{Surface-Water Outflow}

Daily outflow from the lake was measured at the gaging station installed at the bridge crossing the Little Turtle River at the Mercer Lake Outlet (fig. 2). Outflow ranged from about $2 \mathrm{ft}^{3} / \mathrm{s}$ in late summer to $20 \mathrm{ft}^{3} / \mathrm{s}$ in spring (fig. 13C). The average annual surface-water outflow was $7.35 \mathrm{ft}^{3} / \mathrm{s}(5,330$ acre-ft) in MY 2008 and $5.94 \mathrm{ft}^{3} / \mathrm{s}$ (4,300 acre-ft) in MY 2009 (table 8).

\section{Groundwater Flow near and into Mercer Lake}

The two-dimensional, analytic-element, steady-state, groundwater-flow model, GFLOW (Haitjema, 1995) was used to describe the groundwater flow near Mercer Lake, define the groundwater-source area around the lake, and describe the groundwater flow into the lake. A complete description of analytic-element modeling is beyond the scope of this report; however, a brief description is given below. A complete discussion of the methods for applying the model can be found in Strack (1989) and Haitjema (1995).

An infinite aquifer, the underground layer of water-bearing soil and rock, is assumed in analytic-element modeling. In GFLOW, the study area (domain) does not require a grid or involve interpolation between cells. To construct an analyticelement model, features that affect groundwater flow (such 
$\boldsymbol{A}$

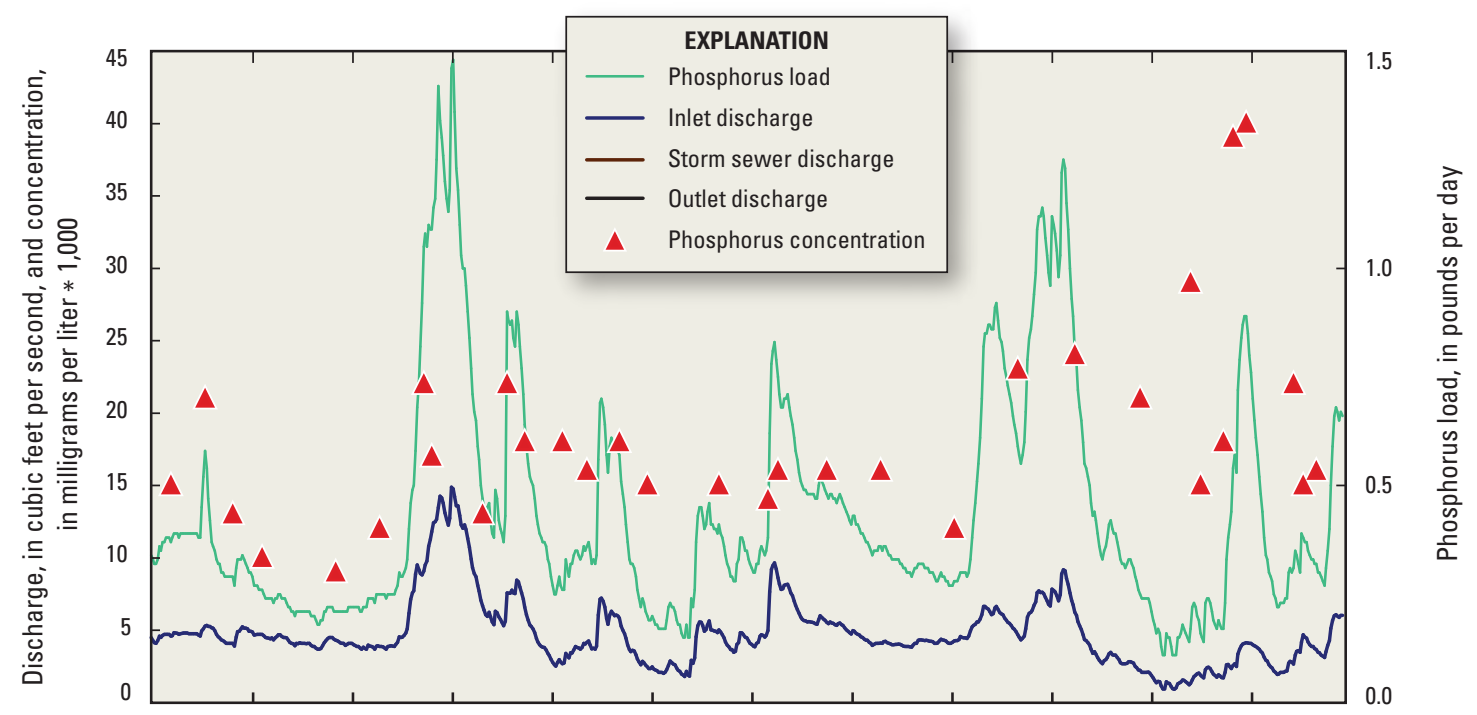

$\boldsymbol{B}$

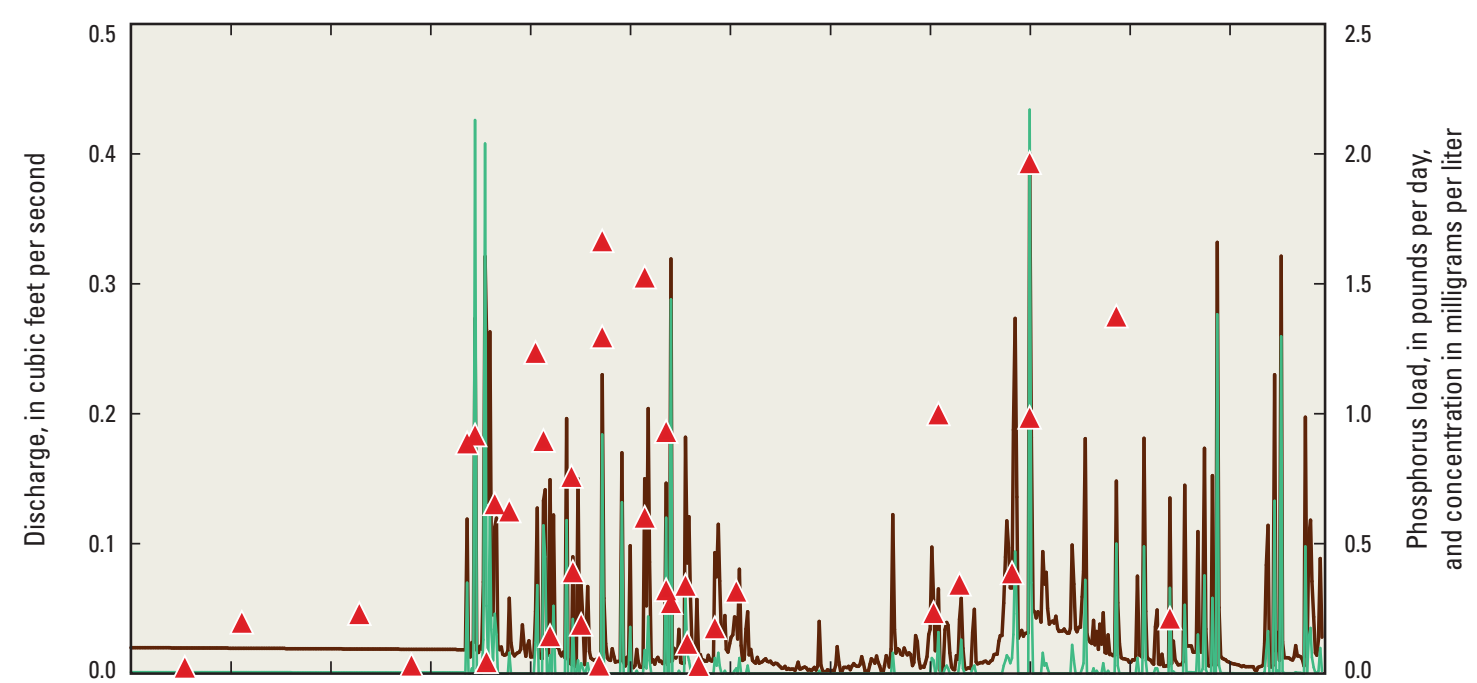

C

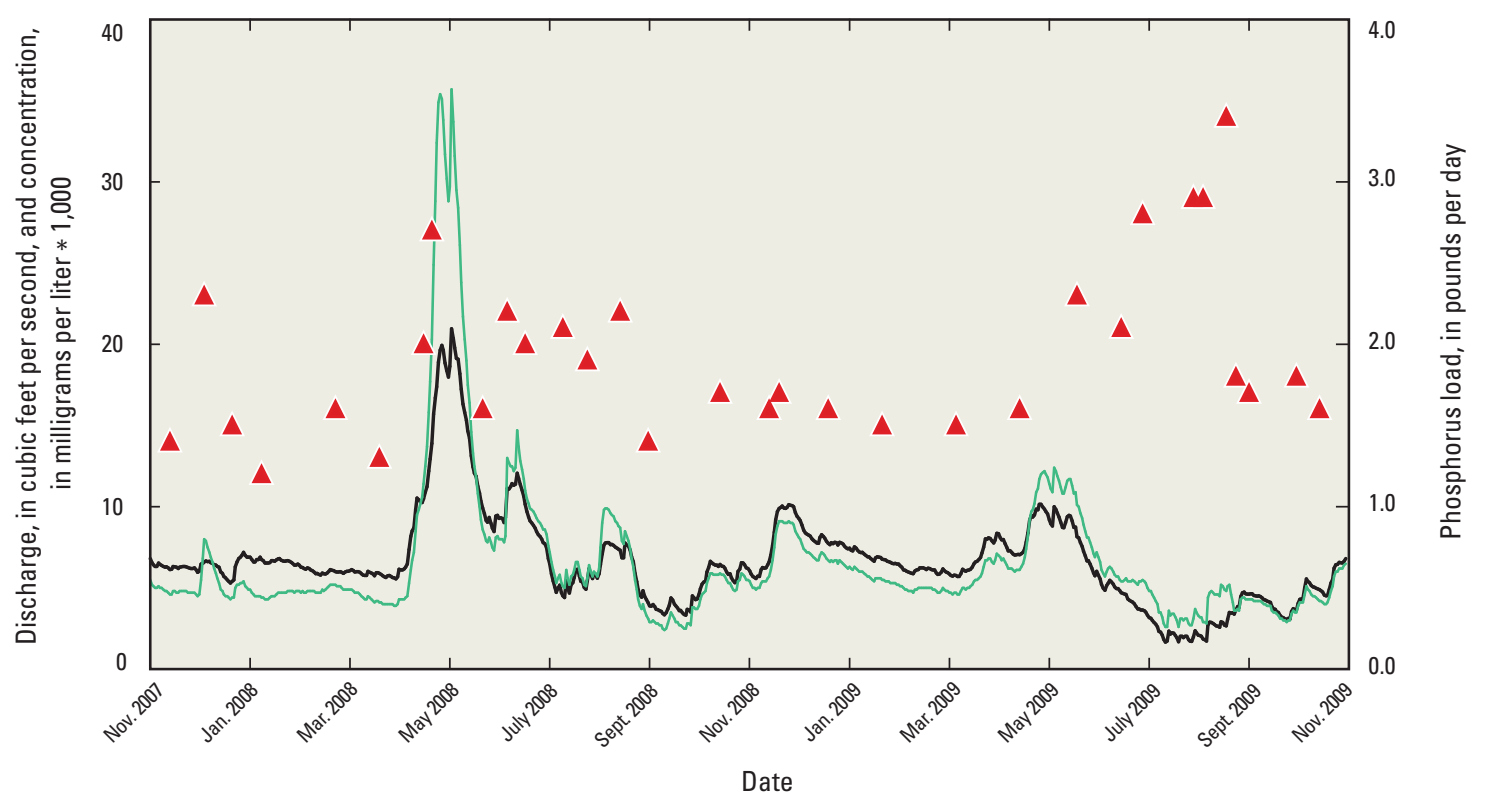

Figure 13. Daily discharge, phosphorus concentrations, and phosphorus loads at $A$, Little Turtle Inlet, $B$, storm drain outlet near the boat landing, and $C$, Mercer Lake Outlet, during monitoring years 2008-09. 
as surface-water bodies, aquifer characteristics, and recharge) are entered as mathematical elements or strings of elements. The amount of detail specified for the features depends on the distance from the area of interest. Each element is represented by an analytic solution. The effects of these individual solutions are added together to arrive at a solution for the groundwater-flow system. In GFLOW, the analytic elements are two dimensional and are used to simulate steady-state conditions. Groundwater-flow systems are three dimensional; however, two-dimensional models can provide reasonable approximations of groundwater flow lines (paths of groundwater movement) when the lengths of the flow lines are long compared to the aquifer thickness (Haitjema, 1995). In the study area, most groundwater was assumed to move through unconsolidated deposits that have a maximum saturated thickness of $200 \mathrm{ft}$. The lengths of flow lines from recharge areas to discharge areas are typically several thousand feet or more in length.

The GFLOW model constructed in this study covers an area extending approximately 5-10 mi around Mercer Lake (fig. 14). The geometry of the single-layer model includes a bottom elevation set at $1,500 \mathrm{ft}$ and an average aquifer thickness of $100 \mathrm{ft}$, which were based on well logs for the study area and additional information from Trotta and Cotter (1973). Recharge was applied uniformly across the simulated area. Surface-water features were simulated using several types of linesink elements. Line sinks are mathematical representation of a stream or lake. They can also be thought of as an infinite number of shallow wells placed along the line, all pumping at a finite rate of discharge. The model includes "far-field" and "near-field" linesinks to represent surface-water features. The near field represents the area of interest and includes Mercer Lake and most adjacent lakes and streams. The far-field area surrounds the near-field area of interest. In the far field, streams and lakes are simulated as coarse linesinks having little or no resistance between the surface-water feature and the groundwater-flow system. Resistance is the force tending to retard groundwater movement. The purpose of simulating the far field is to have the model explicitly define the regional groundwater divide surrounding the area of interest.

Most near-field lakes and streams, which are in good connection with the groundwater-flow system, were included as linesinks with a specified resistance. Some lakes were not simulated, but instead used as water-level targets during calibration. In analytic-element modeling, resistance is computed by dividing the bed-sediment thickness by the vertical hydraulic conductivity of the sediment. Hydraulic conductivity is a measure of the permeability of the aquifer to groundwater movement. Near-field streams were simulated using linesinks with resistance of 0.5 day and widths ranging from 5 to $50 \mathrm{ft}$. Nearfield lakes were simulated as linesinks with resistance values dependent upon the lake type. Resistance was set to 10 days for drainage lakes (those with surface-water inflows and outflows) and 50 days for seepage lakes (those without surfacewater inflows or outflows), which follows the approach used by Juckem and Hunt (2007). Resistance values used in this model are similar to values used in other GFLOW models of areas near Mercer Lake (Hunt and others, 1998; Graczyk and others, 2003, Robertson and others, 2005; Juckem and Hunt, 2007; Garn and others, 2010). Lake widths and depths were determined from USGS topographic maps. Lake stages were measured in September 2008 using a RTK-GPS survey instrument with vertical accuracy of approximately $0.1 \mathrm{ft}$.

The GFLOW model was calibrated using the parameter estimation code PEST (Doherty, 2010). Measured streamflows, lake stages, and water levels from 112 well logs (using measured depth to water and corresponding topographic quadrangle map elevations), along with estimated groundwater inflow to Mercer Lake, were used as groundwater level and flow rate targets during model calibration. The estimated groundwater inflow rate used in the GFLOW model was determined by selecting a value that allowed the calculated stage of the lake (using equation 4, with all of the water-budget components described above) to equal or parallel the actual lake stage for periods when there was little or no runoff from the ungaged near-lake drainage area around the lake. Streamflows and nearby lake levels represented the average flows and levels for the 2-year monitoring period. Water levels for distant lakes were estimated from USGS topographic maps. Because groundwater levels from the 112 well logs were measured over a period of years and well elevations were estimated from topographic maps, these targets were given less weight (weight $=0.2$ ) during calibration than those for lake stages and flows. Weights assigned to targets for calibration were multiplied by the target residual (measured value minus simulated value) to give higher significance to the most accurate and important measurements during the calibration process. Weights for lake stages ranged from 0.2 for distant lakes with water levels estimated from topographic maps to 5 for nearby seepage lakes with measured water levels. Weights for streamflows ranged from 0.00001 to 0.0001 . Although it appears water levels and well logs were given more weight than streamflows, streamflows were actually given relatively higher weights, because streamflows were in units of cubic feet per day, as opposed to water levels that were in units of feet. Weight for groundwater seepage into Mercer Lake was set at 0.005 , a relatively high weight for the calibration. Weights were generally guided by the expected measurement accuracy of the targets, but also by the model objective, which was to simulate the groundwater-contributing area to the lake. Because the groundwater-contributing area is directly related to both recharge and groundwater inflow to the lake, the groundwater-inflow target was the most heavily weighted target. Recharge and horizontal hydraulic conductivity were automatically varied during model calibration until weighted differences between measured and simulated groundwater inflow to Mercer Lake, water levels, lake stages, and streamflows were minimized.

The calibrated model had a recharge rate of $4.7 \mathrm{in} / \mathrm{yr}$ and hydraulic conductivity of $36.1 \mathrm{ft} / \mathrm{d}$. The hydraulic conductivity is similar to values used in previous models developed in other nearby studies (Hunt and others, 1998; Graczyk and others, 2003; Robertson and others, 2005; Garn and others, 2010), 


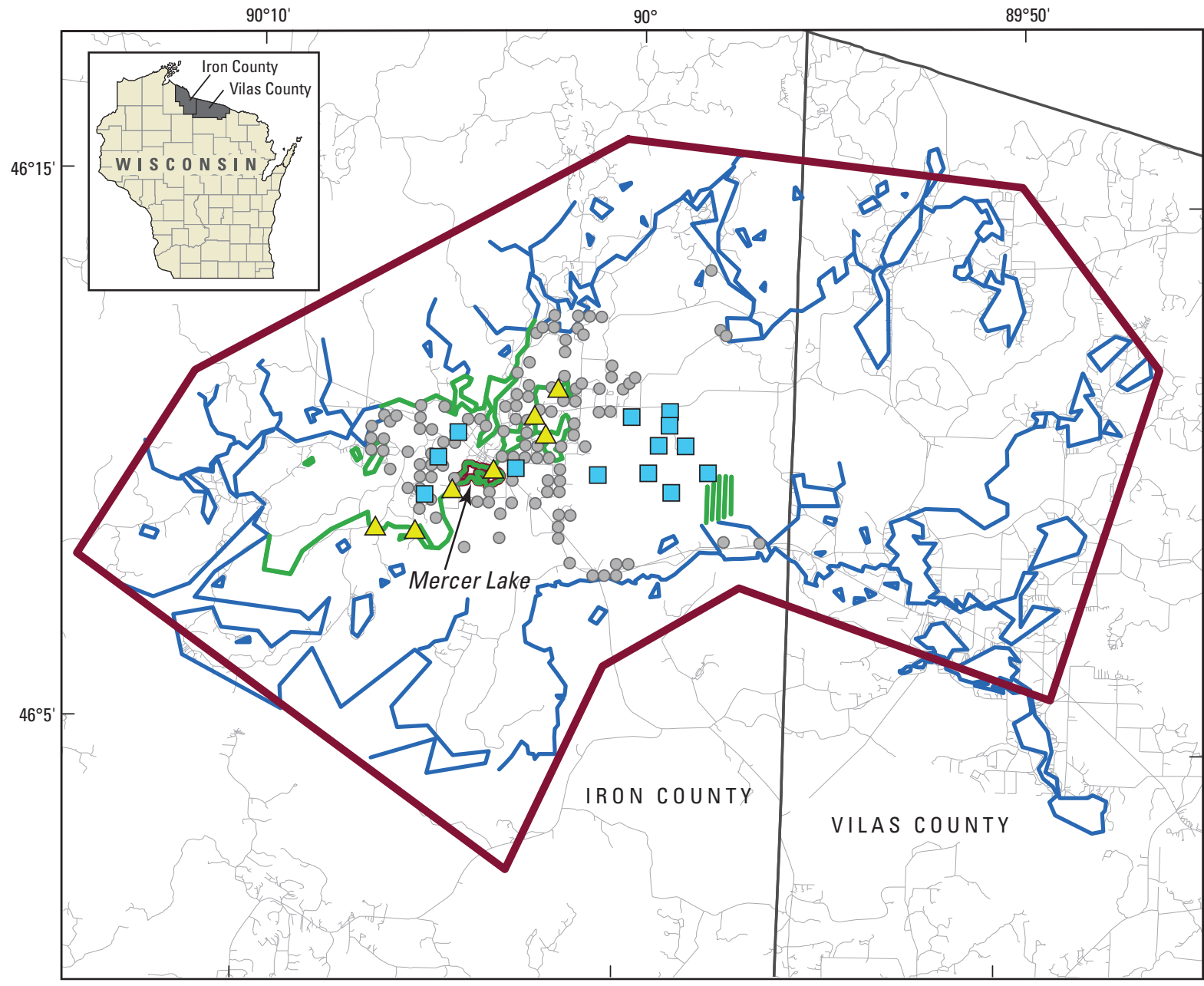

Base map compiled and modified from digital data sources, U.S. Geological Survey, 1:250,000

\section{EXPLANATION}
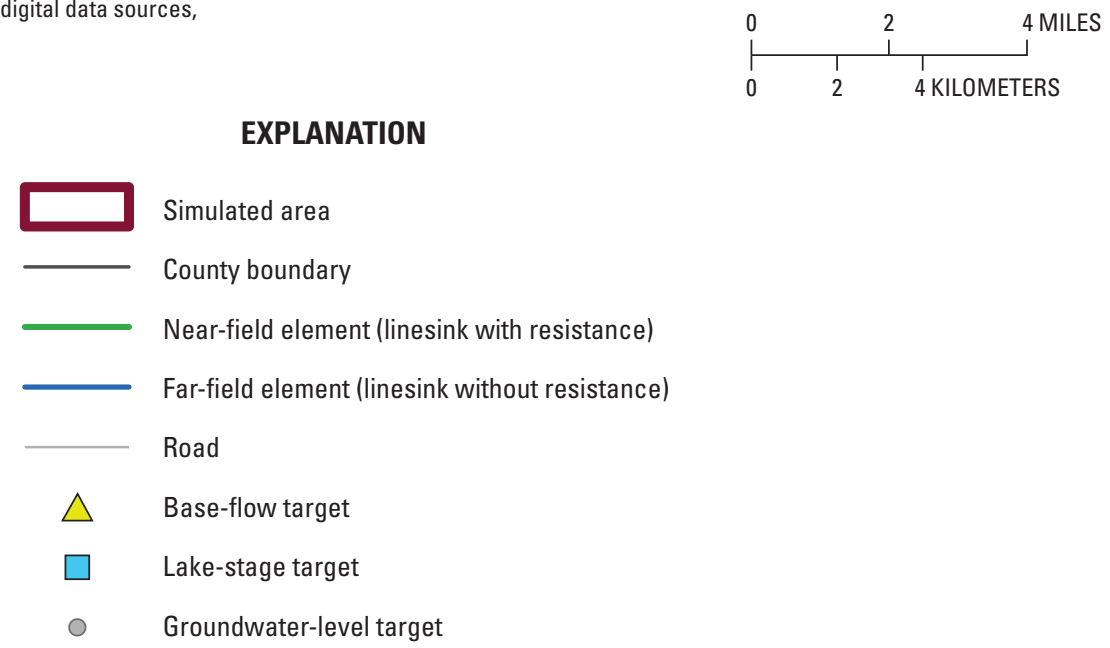

Figure 14. Hydrologic features simulated with the GFLOW analytic groundwater-flow model near Mercer Lake, Iron County, Wis. 


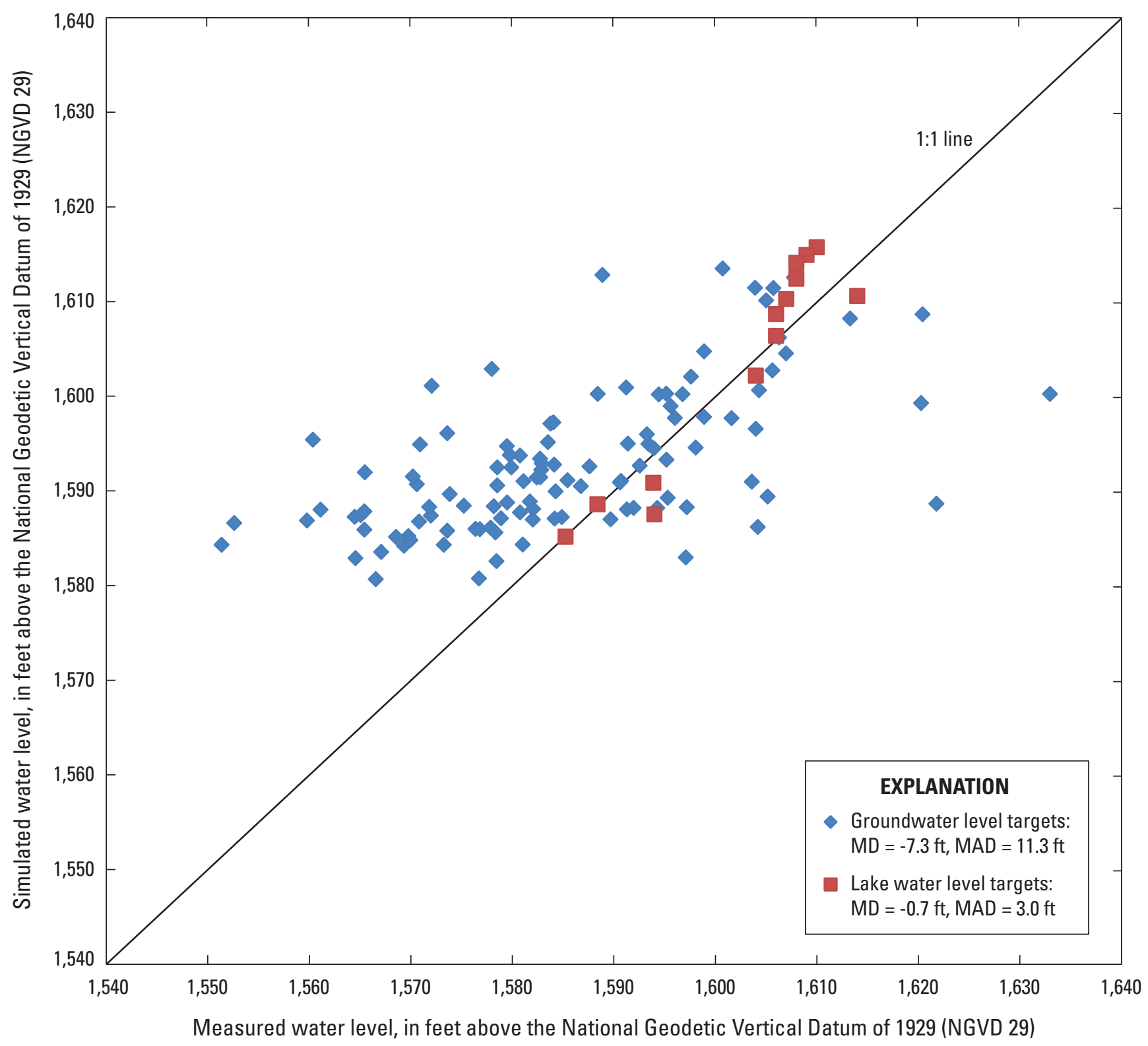

Figure 15. Measured and simulated water levels for the GFLOW model of the area near Mercer Lake, Iron County, Wis. The mean difference (MD) and mean absolute difference (MAD) between the measured and simulated water levels are given on the graph.

but the recharge rate is low and reflects the influence of the prolonged drought in the region. The recharge rate is within the range estimated by Dripps and others (2006) for the period 1996-2000, a period prior to the start of the drought, but it is not expected to represent "normal" hydrologic conditions. Simulated heads and flows were reasonably close to measured values. The mean and mean absolute difference between simulated and measured groundwater levels were -7.3 and $11.3 \mathrm{ft}$, respectively (fig. 15). For lake stages within the modeled area, mean and mean absolute differences were -0.7 and $3.0 \mathrm{ft}$, respectively (fig. 15). The mean and mean absolute differences for streamflow were 0.6 and $0.7 \mathrm{ft}^{3} / \mathrm{s}$, respectively (fig. 16). Groundwater inflow to Mercer Lake was within 0.1 percent of the target value (fig. 16).
Based on the similarity between measured and simulated water levels and flows, the model appears to accurately simulate groundwater flow near Mercer Lake during MY 2008-09. The model represents one set of steady-state, baseflow conditions; however, in reality there are seasonal variations in groundwater levels, lake stage, and streamflow. It was assumed that seasonal variations in groundwater levels and natural lake stages would be relatively uniform throughout the model area, thus having minimal effect on the extent of the groundwater-contributing areas as well as the net gains and losses to the groundwater-flow system immediately adjacent to near-field lakes. In addition, it was assumed that human-induced seasonal changes in lake stages (dams) would cause only short-term effects on gains and losses 


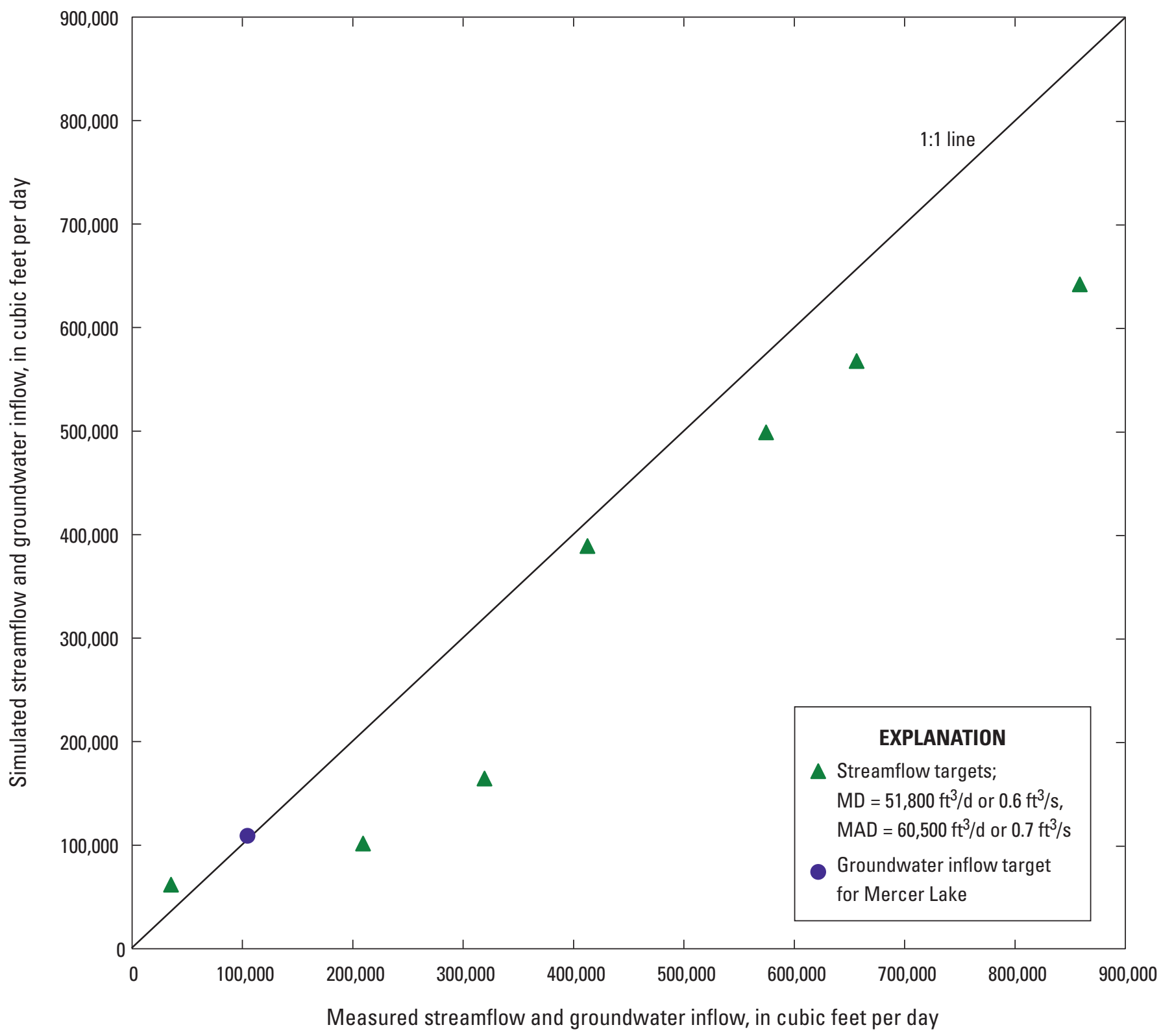

Figure 16. Measured and simulated streamflow and groundwater inflow to Mercer Lake for the GFLOW model of the area near Mercer Lake, Iron County, Wis. The mean difference (MD) and mean absolute difference (MAD) between the measured and simulated streamflows and inflows are given on the graph.

and that those effects would be minimal on an annual basis. Based on these assumptions, the model can be used to define groundwater-contributing areas around Mercer Lake. It was further assumed that groundwater-flow directions remained relatively constant over a range of dry and wet years, because the water level change in the surrounding drainage lakes is small. To evaluate the influence of recharge rates on the groundwater-contributing area, a range of recharge rates, from the calibrated rate of $4.7 \mathrm{in} / \mathrm{yr}$ to $10 \mathrm{in} / \mathrm{yr}$ (a more reasonable estimate for "typical" conditions), were simulated with the model, whereas linesink elevations remained unchanged in the simulation. As expected, this change in recharge rates had relatively little influence on the simulated groundwater-contributing area to Mercer Lake. Thus, lacking differential changes in surface-water elevations, higher recharge during more typical years will simply change the amount of water flowing through the system, but not flow directions.

The groundwater-contributing area for Mercer Lake was delineated using particle-tracking techniques in GFLOW. The groundwater-contributing area covers $3.0 \mathrm{mi}^{2}$ (shaded area 


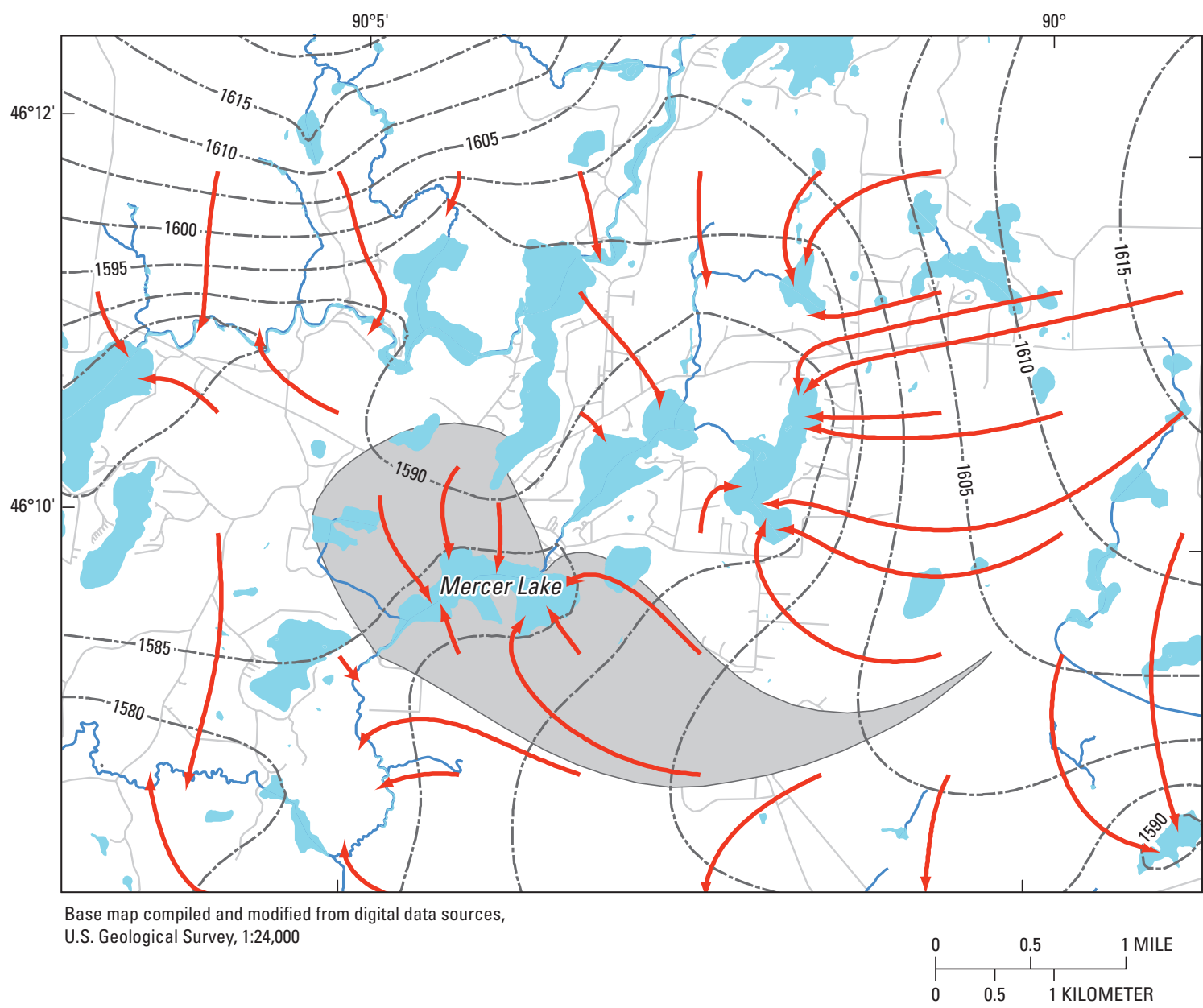

EXPLANATION

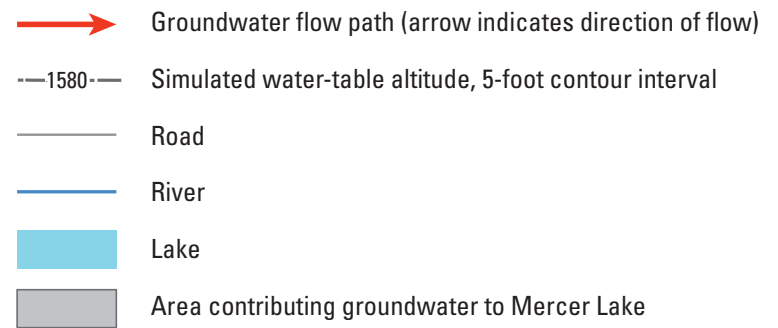

Figure 17. Simulated groundwater-flow directions and area contributing groundwater to Mercer Lake, Iron County, Wis.

in fig. 17) and extends beyond the surface-water contributing area, particularly to the south and east of Mercer Lake. Simulated groundwater flow indicates that discharge (groundwater input) occurs along the entire shoreline surrounding Mercer Lake, which matches the results from the near-lake piezometers. Net groundwater flow into the lake by direct discharge along shoreline segments was simulated to be $1.21 \mathrm{ft}^{3} / \mathrm{s}$ (about 877 acre-ft per year) for MY 2008-09. The area of greatest groundwater discharge to Mercer Lake is along the east and northwest shorelines (fig. 17).
Although this model was considered reasonably calibrated and was sufficient for estimates of groundwater inflow to Mercer Lake during the monitoring period, local heterogeneities that were not simulated with the model may locally alter the contributing area to a small degree. Use of the model for evaluations beyond the stated purpose (to estimate groundwater-contributing areas to the lake and groundwater exchanges with the lake) may require reevaluation of the model and may require recalibration of the model to match new or existing data that correspond to the new purpose. 
Water inputs: 2-year average $(5,180$ acre-feet $)$

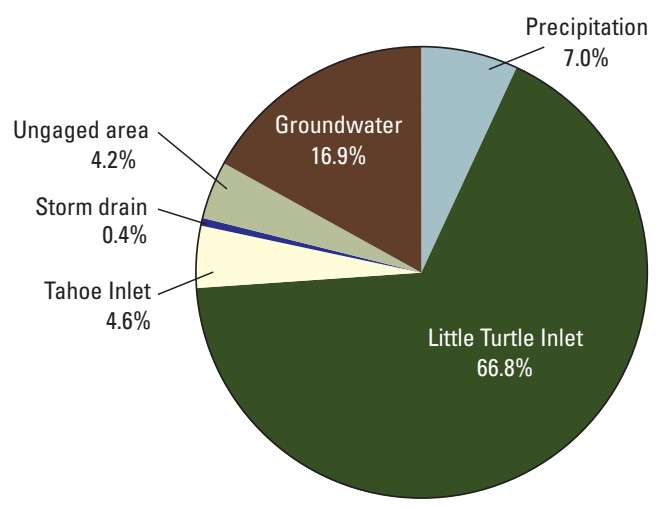

Water inputs: typical year (7,150 acre-feet)

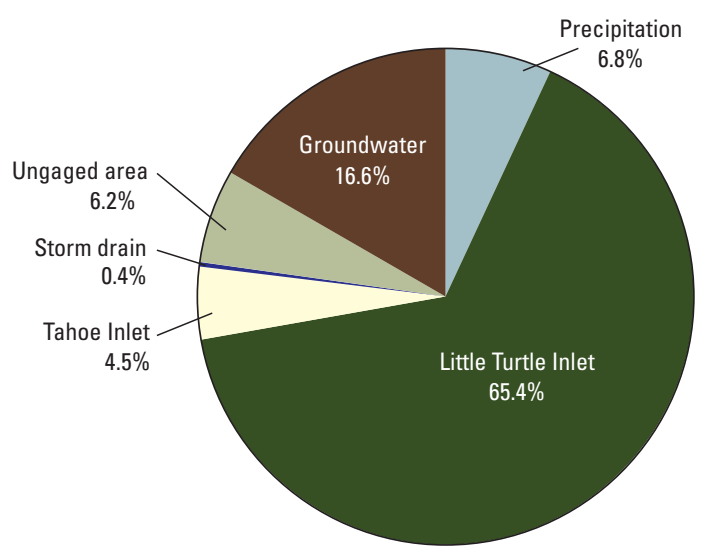

Water outputs: 2-year average $(5,190$ acre-feet $)$

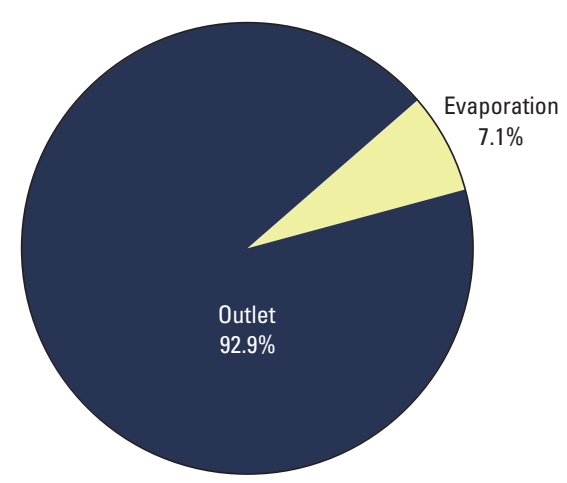

Water outputs: typical year $(7,150$ acre-feet $)$

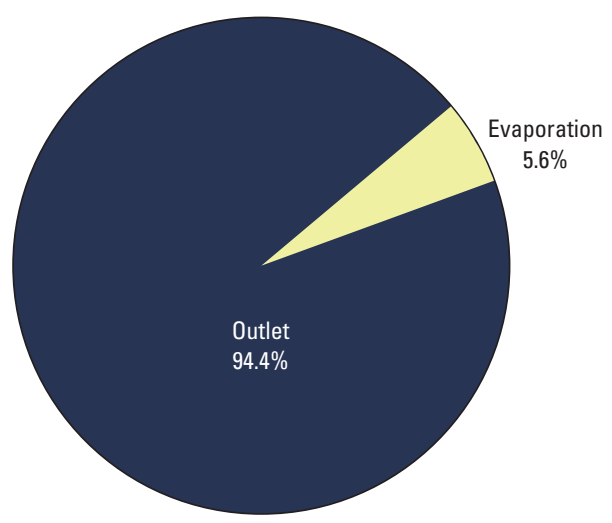

Figure 18. Water budgets for Mercer Lake, Iron County, Wis., for monitoring years 2008-09 and for typical hydrologic conditions.

\section{Ungaged Near-Lake Drainage Area}

Flow from the near-lake drainage area (fig. 2) includes unchannelized runoff going directly into the lake, runoff conveyed in numerous small channels, and additional runoff from the parts of the town that are drained by storm sewers. Part of this runoff is from the gaged storm-drain outlet, but the approach used to estimate the ungaged near-lake runoff removes this monitored runoff. The ungaged near-lake runoff was estimated as the residual in the mass-balance equation (eq. 4) after all other inputs, including that from groundwater, and outputs were determined. The annual average flow from the remaining ungaged near-lake area was estimated to be $0.49 \mathrm{ft}^{3} / \mathrm{s}$ (359 acre-ft) in MY 2008 and $0.10 \mathrm{ft}^{3} / \mathrm{s}$ (72 acre-ft) in MY 2009 (table 8).

\section{Water-Budget Summary}

The Little Turtle Inlet is the largest source of water to Mercer Lake, supplying about 67 percent of the total input during the 2-year study period (table 8; fig. 18). Other sources were groundwater (16.9 percent), precipitation (7.0 percent), Tahoe Inlet (4.6 percent) and the total near-lake drainage that includes the urbanized area and storm drain (4.6 percent).

The total input of water in MY 2008 (5,680 acre-ft) was more than in MY 2009 (4,680 acre- $\mathrm{ft}$ ) because of the prolonged dry period and below-normal precipitation. The residence timethat is, the length of time required for water entering the lake to completely replace the volume of water in the lake-was 0.46 years, computed on the basis of the average inflow (total runoff plus precipitation minus evaporation and not including groundwater inputs) for the 2 monitoring years. 


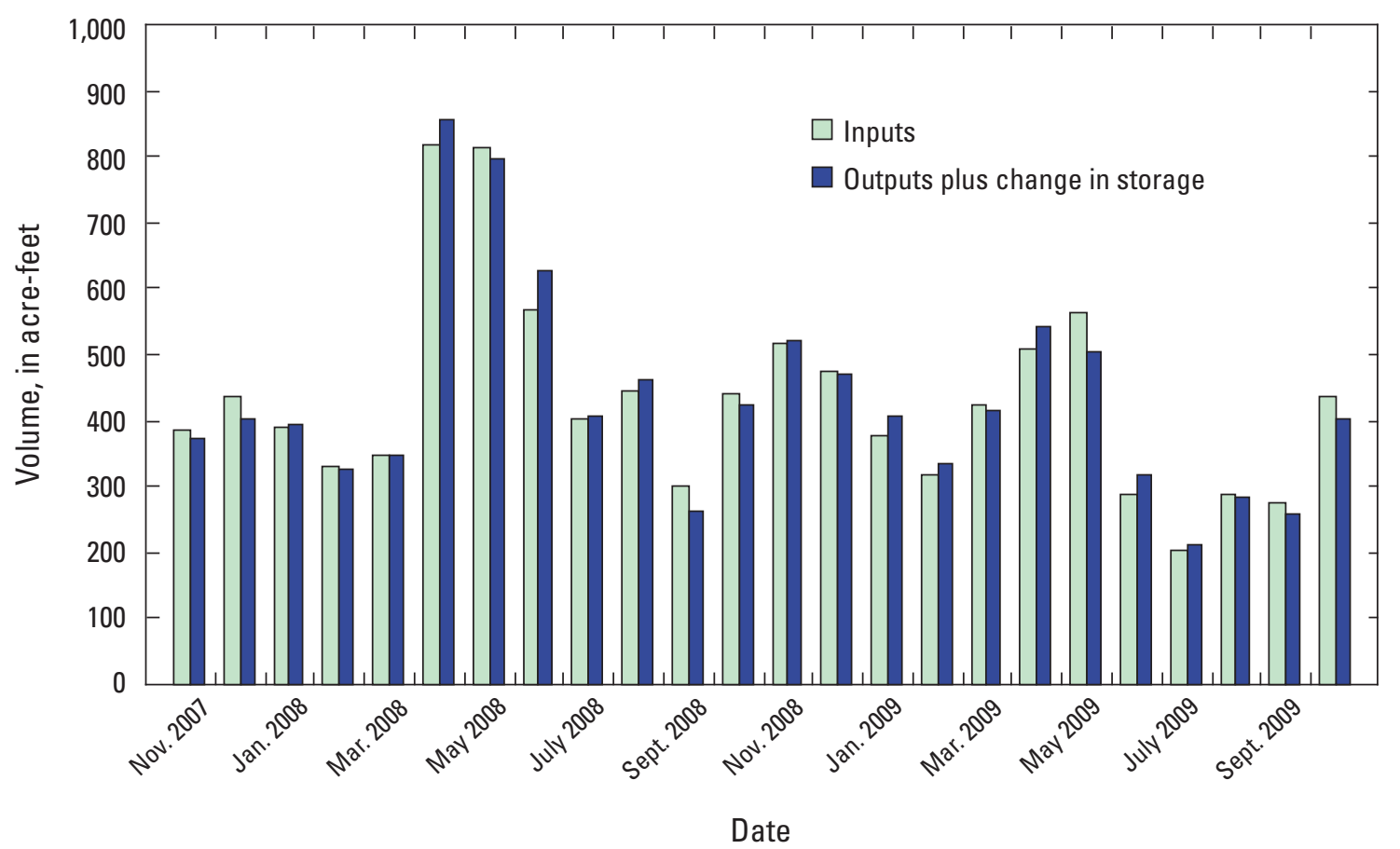

Figure 19. Monthly accuracy of the water budget on the basis of comparisons of total water inputs and outputs plus storage change for Mercer Lake, Iron County, Wis., during monitoring years 2008-09.

The total annual output of water from the lake was very similar to the total input in both years, resulting in little change in storage from the beginning to the end of each study year. On average, about 93 percent of the total water leaving the lake left through the Mercer Lake Outlet and 7 percent left through evaporation (table 8; fig. 18). Based on results from the piezometers installed around the lake and the groundwater model, little water left the lake to the groundwater system.

The quality or accuracy of the water budget was evaluated by comparing the monthly sum of all inputs with the sum of all outputs plus the change in storage for the lake (fig. 19). The differences between the calculated inputs and outputs reflect the cumulative errors in the estimates of all of the components in the water budget. The water budget was relatively accurate on a monthly and annual time scale. The largest monthly difference were in June 2008 and May 2009, which when expressed as percentages of the total measured output plus change in storage were 9.5 in June 2008 and 11.9 percent in May 2009. On an annual basis, the percentage error was about 0.1 percent for both years.

The hydrology documented in MY 2008-09 represents conditions during a series of dry years. To determine how the hydrologic loading to the lake would change under more typical hydrologic conditions, inputs for each of the budget components (table 8) were estimated during long-term average hydrologic conditions. During MY 2008-09, precipitation was 74 percent of the long-term average; therefore, precipitation, runoff volumes in the Little Turtle Inlet, storm drain, and Tahoe Inlet, and groundwater input were increased by 26 percent. A 26-percent increase in the input from the ungaged near-lake area was less than that input during MY 2008; therefore, the input from the ungaged near-lake area in MY 2009 (the wetter year) was increased by 18.5 percent, because precipitation in 2009 was 18.5 percent below the long-term average. During typical hydrologic conditions, evaporation from the lake was assumed to be equal to the average total annual free-surface evaporation of $26.2 \mathrm{in}$. estimated for the area by Farnsworth and others (1982). Outflow from the lake was then estimated from the total inputs to the lake minus that leaving the lake through evaporation and assuming that there were no long-term changes in water level. The resulting hydrologic inputs during average hydrologic conditions are given in table 8 and figure 18. During typical hydrologic conditions, the total water input is estimated to be 7,150 acre-ft, which is an increase of 38 percent from that measured in MY 2008-09. 


\section{Sources of Phosphorus}

To help define where the phosphorus in Mercer Lake originates and how much may be controllable, a detailed phosphorus budget was computed for each monitoring year, and then this information was used to estimate the phosphorus budget for a year with typical hydrologic conditions. External sources of phosphorus to the lake include precipitation, surface-water and groundwater inflow, and contributions from septic systems. In addition to these external sources, phosphorus can be released from the bottom sediments of the lake, which is considered an internal source of phosphorus (internal loading). Phosphorus is removed from the lake through surface-water outflow and deposition to the lake sediments.

\section{Precipitation}

Atmospheric deposition of phosphorus on Mercer Lake was determined from phosphorus concentrations measured in wetfall (rain and snow) and phosphorus-deposition rates measured in dryfall (dry particles from the atmosphere) at a weather station previously operated at Whitefish Lake in Douglas County, Wis. (Robertson, Rose, and Juckem, 2009). Total monthly wetfall deposition was computed by multiplying the average estimated phosphorus concentration of $0.016 \mathrm{mg} / \mathrm{L}$ by the monthly precipitation on the lake. Phosphorus in dryfall was estimated from deposition rates measured at Whitefish Lake, which was adjusted for lakes with few conifers in the surrounding area and was approximately $26 \mathrm{lb} / \mathrm{mi}^{2} / \mathrm{yr}$, equally distributed from May through October. Total phosphorus inputs to the lake from precipitation were 24.9 lb in MY 2008 and $21.7 \mathrm{lb}$ in MY 2009 (table 9).

\section{Surface-Water Inflow}

Phosphorus inputs (loads) were computed for the continuously monitored sites at the Little Turtle Inlet, the storm drain near the boat landing, and at the Mercer Lake Outlet. Phosphorus loads were also estimated for the Tahoe Inlet and the ungaged near-lake drainage area.

\section{Gaged Inlets}

Phosphorus in Little Turtle Inlet at Garnet Street (fig. 2) originates from the upper watershed, including Grand Portage Lake and other upstream lakes. Total phosphorus concentrations from 34 samples collected during the 2-year study period ranged from 0.009 to $0.040 \mathrm{mg} / \mathrm{L}$ (fig. 13A). The median and volumetrically weighted concentrations were 0.016 and $0.018 \mathrm{mg} / \mathrm{L}$, respectively. About 50 percent of the phosphorus was in the dissolved form, but this was based on only two samples. Daily phosphorus loads from the inlet were computed with GCLAS and summed to obtain annual totals. The total quantity of phosphorus delivered from Little Turtle
Inlet was $152 \mathrm{lb}$ in MY 2008 and $169 \mathrm{lb}$ in MY 2009 (table 9). Annual yields from Little Turtle Inlet watershed were $14.8 \mathrm{lb} / \mathrm{mi}^{2}$ in MY 2008 and $16.5 \mathrm{lb} / \mathrm{mi}^{2}$ in MY 2009. These yields are slightly less than those measured for the Bear River watershed near Manitowish Waters in the Northern Lakes and Forests ecoregion (24 lb/ $\mathrm{mi}^{2}$; Corsi and others, 1997). The yields measured in this study are likely lower than those of the other studies because the two study years (MY 2008-09) were characterized by below-average precipitation and runoff and because of the trapping effect of the upstream lakes.

Phosphorus in Tahoe Inlet originates from the Tahoe Lake watershed, Tahoe Lake, and the forest and wetland areas downstream of Tahoe Lake. Total phosphorus concentrations from 10 samples collected during the 2-year study ranged from 0.017 to $0.082 \mathrm{mg} / \mathrm{L}$. The median and volumetrically weighted concentrations of total phosphorus were both $0.036 \mathrm{mg} / \mathrm{L}$. Daily phosphorus loads were determined by multiplying the volumetrically weighted concentration from all of the samples measured at this site by the estimated daily flows. The total quantity of phosphorus estimated from this inlet was $24.3 \mathrm{lb}$ in MY 2008 and 22.8 lb in MY 2009.

Phosphorus in the storm drain near the boat landing originates mostly from urban sources, including runoff from streets in Mercer. Total phosphorus concentrations from 36 samples collected during the 2-year study ranged from 0.019 to $1.96 \mathrm{mg} / \mathrm{L}$ (fig. $13 B$ ). The median and volumetrically weighted concentrations of total phosphorus were 0.360 and $0.833 \mathrm{mg} / \mathrm{L}$, respectively. About 50 percent of the phosphorus was in the dissolved form, but this was based on only two samples. Daily phosphorus loads were computed with GCLAS and summed to obtain annual totals. The total quantity of phosphorus measured at this storm drain was $15.0 \mathrm{lb}$ in MY 2008 and $12.7 \mathrm{lb}$ in MY 2009.

\section{Ungaged Near-Lake Drainage Areas}

The phosphorus concentration in the inflow from the ungaged near-lake drainage areas was estimated from phosphorus concentrations measured in the storm drain and at Tahoe Inlet. It was assumed that the flow from the ungaged near-lake area consisted of water from a combination of sources similar to that from the storm drain (20 percent) and the Tahoe Lake watershed ( 80 percent). Therefore, the phosphorus concentration for flow from these areas was set equal to $0.2 *$ volumetrically weighted concentration from the storm drain $+0.8^{*}$ volumetrically weighted concentration from Tahoe Inlet, or set equal to $0.076 \mathrm{mg} / \mathrm{L}$. Daily phosphorus loads were then determined by multiplying the volumetrically weighted concentration $(0.076 \mathrm{mg} / \mathrm{L})$ by the estimated daily flows for the ungaged area. The total quantity of phosphorus measured from the ungaged area was $74.0 \mathrm{lb}$ in MY 2008 and $14.9 \mathrm{lb}$ in MY 2009 (table 9). Loading during MY 2009 was much less than that in MY 2008 because the very dry conditions resulted in a lack of runoff from this area. 
Table 9. Summary of the phosphorus-budget components for Mercer Lake, Iron County, Wis., during monitoring years 2008-09, during typical hydrologic conditions, and with future development in the watershed.

[Monitoring year, November-October; MY, monitoring year; all data in pounds per year; - , not estimated; bold type indicates total inputs to the lake]

\begin{tabular}{|c|c|c|c|c|c|c|c|c|c|c|}
\hline \multirow{2}{*}{$\begin{array}{c}\text { Budget } \\
\text { component }\end{array}$} & \multirow[b]{2}{*}{ MY 2008} & \multirow[b]{2}{*}{ MY 2009} & \multirow{2}{*}{$\begin{array}{c}\text { 2-year } \\
\text { average }\end{array}$} & \multirow{2}{*}{$\begin{array}{c}\text { Percentage } \\
\text { of 2-year } \\
\text { total }\end{array}$} & \multirow{2}{*}{$\begin{array}{c}\text { Typical } \\
\text { hydrology }\end{array}$} & \multirow[b]{2}{*}{ Pre-1965 } & \multicolumn{3}{|c|}{$1965-95$} & \multirow[b]{2}{*}{ Future } \\
\hline & & & & & & & $\begin{array}{l}0 \text {-percent } \\
\text { retention }\end{array}$ & $\begin{array}{l}\text { 10-percent } \\
\text { retention }\end{array}$ & $\begin{array}{l}\text { 25-percent } \\
\text { retention }\end{array}$ & \\
\hline \multicolumn{11}{|c|}{ Inputs to lake } \\
\hline Precipitation & 24.9 & 21.7 & 23.3 & 6.9 & 28.8 & 28.8 & 28.8 & 28.8 & 28.8 & 28.8 \\
\hline Little Turtle Inlet & 152 & 169 & 160 & 47.2 & 217 & 217 & 217 & 217 & 217 & 217 \\
\hline Tahoe Inlet & 24.3 & 22.8 & 23.5 & 6.9 & 31.8 & 31.8 & 31.8 & 31.8 & 31.8 & 31.8 \\
\hline Storm drain & 15.0 & 12.7 & 13.8 & 4.1 & 18.7 & 18.7 & 18.7 & 18.7 & 18.7 & 11.9 \\
\hline Ungaged area & 74.0 & 14.9 & 44.4 & 13.1 & 90.7 & 90.7 & 90.7 & 90.7 & 90.7 & 57.7 \\
\hline Groundwater & 39.5 & 39.3 & 39.4 & 11.6 & 53.3 & 53.3 & 53.3 & 53.3 & 53.3 & 53.3 \\
\hline Septic systems & 8.6 & 8.6 & 8.6 & 2.5 & 8.6 & 349 & 31.7 & 167 & 374 & 8.6 \\
\hline Total external input & 338 & 289 & 313 & 92.3 & 449 & 789 & 472 & 609 & 814 & 409 \\
\hline $\begin{array}{l}\text { Internal (sediment) } \\
\text { loading }\end{array}$ & 26.3 & 26.3 & 26.3 & 7.7 & 26.3 & 26.3 & 26.3 & 26.3 & 26.3 & 26.3 \\
\hline $\begin{array}{l}\text { Total external and } \\
\text { internal input }\end{array}$ & 364 & 315 & 340 & 100 & 475 & 816 & 498 & 635 & 840 & 435 \\
\hline \multicolumn{11}{|c|}{ Outputs from lake } \\
\hline Little Turtle Outlet & 271 & 214 & 243 & 71.4 & - & - & - & - & - & - \\
\hline
\end{tabular}




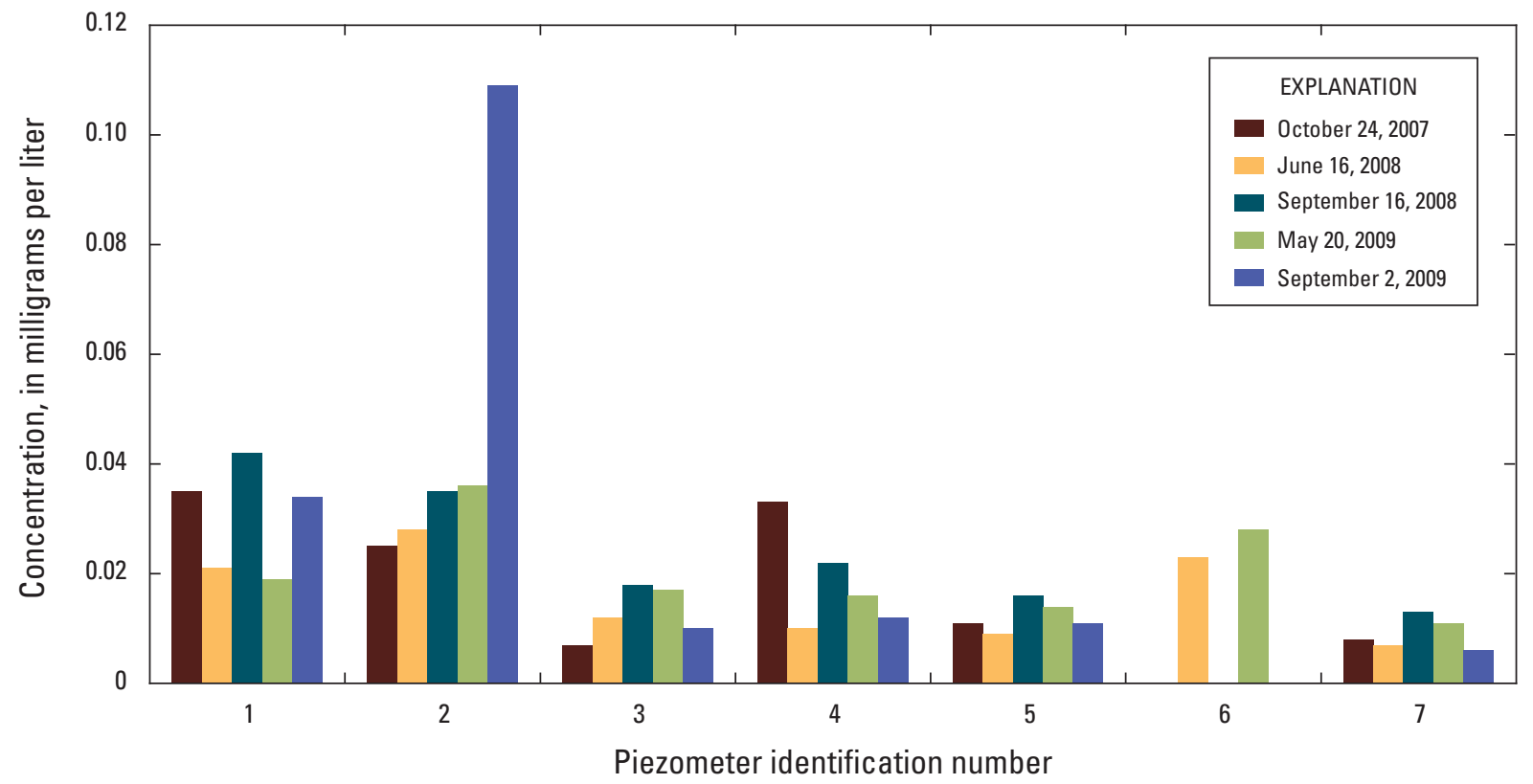

Figure 20. Concentrations of dissolved phosphorus in groundwater from piezometers near Mercer Lake, Iron County, Wis.

\section{Groundwater}

Loading of phosphorus from natural groundwater inflow and from contributions from septic systems in the groundwater were estimated separately. To determine the natural groundwater contributions, piezometers were installed around the lakeshore (fig. 2) and sampled to determine the concentrations of dissolved phosphorus in groundwater entering the lake (fig. 20). Based on water-elevation gradients and the groundwater model, groundwater enters the lake from the entire shoreline, with the possibility of a slight flow reversal near the boat landing. Average dissolved phosphorus concentrations in each of piezometers ranged from $0.012 \mathrm{mg} / \mathrm{L}$ at P5, near the outlet, to $0.047 \mathrm{mg} / \mathrm{L}$ at P2, on the northwest side of the lake. The average concentration of all samples was $0.022 \mathrm{mg} / \mathrm{L}$, whereas the median concentration was $0.017 \mathrm{mg} / \mathrm{L}$. Phosphorus concentrations in some piezometers, such as piezometer P2, may be elevated above background concentrations and likely affected by septic-tank effluent or urban sources. Therefore, to estimate the phosphorus input to the lake from natural groundwater inflow, it was assumed that the concentration of groundwater entering the lake was equal to the median concentration measured in the piezometers (0.017 mg/L). During MY 2008-09, the annual phosphorus load contributed by natural groundwater inflow was estimated to be about $40 \mathrm{lb}$ (table 9).

\section{Septic Systems}

Phosphorus loading from near-lake septic systems was estimated separately from background groundwater inflow by applying export coefficients to the near-lake septic systems. The latest population and occupancy information, site-specific soil information, and septic-system characteristics were evaluated and used to estimate the site-specific coefficients.

The input of phosphorus from septic systems $(M)$ was estimated by use of equation 5 (Reckhow and others, 1980):

$$
M=E_{s} *(\text { number of capita years }) *\left(1-S_{R}\right),
$$

where $M$ is a function of a phosphorus export coefficient, $E_{s}$, a soil retention coefficient, $S_{R}$, and the number of people using the septic systems annually (capita years). This method of estimating phosphorus loading from septic systems is described in more detail by Garn and others (1996). In applying equation 5, it was assumed that the most likely value for $E_{s}$ was $1.5 \mathrm{lb}$ of phosphorus per capita per year (table 10). Typical export coefficients range from about $1.0 \mathrm{lb}$ per capita per year (Reckhow and others, 1980; Panuska and Kreider, 2003) to over $2 \mathrm{lb}$ per capita per year (Garn and others, 1996). Soils of the area around Mercer Lake consist predominantly of the Vilas-Lindquist Complex, Keweenaw-Pence Complex, Manitowish sandy loam, Annalake fine sandy loam, Padus and Pence sandy loam, and Seelyeville and Markey soils (Natural Resources Conservation Service, 2010). Many of these soils are underlain by sand and gravel, are well drained, have high subsoil permeabilities, and are classified as a poor filter with very limited application for septic-tank absorption fields. More than 75 percent of soils in the area are very limited for disposal of wastewater by infiltration. Therefore, an $S_{R}$ coefficient of 0.5 was used for these soils, plus an $S_{R}$ of 0.2 was added for the fraction of the phosphorus that is removed by storage of solids in the septic tank. Therefore, a most likely $S_{R}$ value of 0.70 (70-percent retention) was used in septic system input calculations (table 10). 
Table 10. Phosphorus input from septic systems, sewage treatment plants, and untreated areas into Mercer Lake, Iron County, Wis.

[ $\mathrm{E}_{\mathrm{s}}$, phosphorus export coefficient; $\mathrm{S}_{\mathrm{R}}$, soil retention coefficient; lb, pounds; - , not applicable]

\begin{tabular}{|c|c|c|c|c|c|c|c|c|c|c|c|c|c|}
\hline \multirow[b]{2}{*}{$\begin{array}{l}\text { Scenario / time } \\
\text { period }\end{array}$} & \multirow[b]{2}{*}{ Occupancy } & \multirow[b]{2}{*}{$\mathbf{E}_{\mathrm{s}}$} & \multirow[b]{2}{*}{$\mathbf{S}_{\mathrm{R}}$} & \multicolumn{3}{|c|}{ Houses } & \multicolumn{3}{|c|}{ Resorts } & \multirow[b]{2}{*}{$\begin{array}{c}\text { Total } \\
\text { capita } \\
\text { years }\end{array}$} & \multirow{2}{*}{$\begin{array}{c}\text { Septic } \\
\text { system } \\
\text { input } \\
\text { (Ib) }\end{array}$} & \multirow{2}{*}{$\begin{array}{l}\text { Sewage } \\
\text { input to } \\
\text { lake } \\
\text { (Ib) }\end{array}$} & \multirow[b]{2}{*}{$\begin{array}{l}\text { Total input } \\
\text { to lake } \\
\text { (lb) }\end{array}$} \\
\hline & & & & Number & $\begin{array}{l}\text { Residents } \\
\text { per unit }\end{array}$ & $\begin{array}{l}\text { Fraction } \\
\text { of year } \\
\text { occupied }\end{array}$ & Number & $\begin{array}{l}\text { Residents } \\
\text { per unit }\end{array}$ & $\begin{array}{l}\text { Fraction } \\
\text { of year } \\
\text { occupied }\end{array}$ & & & & \\
\hline \multirow[t]{2}{*}{ MY 2008-09 } & Permanent & 1.5 & 0.7 & 7 & 2.1 & 1 & 0 & 0 & 0 & 14.7 & 6.6 & 0.0 & 6.6 \\
\hline & Seasonal & 1.5 & 0.7 & 7 & 2.1 & 0.3 & 0 & 0 & 0 & 4.4 & 2.0 & 0.0 & 2.0 \\
\hline Total & & - & - & - & - & - & - & - & - & 19.1 & 8.6 & 0.0 & 8.6 \\
\hline \multirow[t]{2}{*}{ Pre-1965 } & Permanent & 1.5 & 0.5 & 16 & 2.1 & 1 & 0 & 0 & 0 & 33.6 & 25.2 & 285 & 310 \\
\hline & Seasonal & 1.5 & 0.5 & 49 & 2.1 & 0.3 & 6 & 12 & 0.3 & 52.5 & 39.4 & 0.0 & 39.4 \\
\hline Total & & - & - & - & - & - & - & - & - & 86.1 & 64.6 & 285 & 349 \\
\hline \multicolumn{14}{|l|}{ 1965-95 } \\
\hline \multirow{2}{*}{$\begin{array}{l}0 \text { percent } \\
\text { retention in lake }\end{array}$} & Permanent & 1.5 & 0.7 & 13 & 2.1 & 1 & 0 & 0 & 0 & 27.3 & 12.3 & 0.0 & 12.3 \\
\hline & Seasonal & 1.5 & 0.7 & 40 & 2.1 & 0.3 & 0 & 0 & 0 & 43.2 & 19.4 & 0.0 & 19.4 \\
\hline Total & & - & - & - & - & - & - & - & - & 70.5 & 31.7 & 0.0 & 31.7 \\
\hline \multirow{2}{*}{$\begin{array}{l}10 \text { percent } \\
\text { retention in lake }\end{array}$} & Permanent & 1.5 & 0.7 & 13 & 2.1 & 1 & 0 & 0 & 0 & 27.3 & 12.3 & 137 & 149 \\
\hline & Seasonal & 1.5 & 0.7 & 40 & 2.1 & 0.3 & 5 & 12 & 0.3 & 43.2 & 19.4 & 0.0 & 19.4 \\
\hline Total & & - & - & - & - & - & - & - & - & 70.5 & 31.7 & 137 & 169 \\
\hline \multirow{2}{*}{$\begin{array}{l}25 \text { percent } \\
\text { retention in lake }\end{array}$} & Permanent & 1.5 & 0.7 & 13 & 2.1 & 1 & 0 & 0 & 0 & 27.3 & 12.3 & 342 & 354 \\
\hline & Seasonal & 1.5 & 0.7 & 40 & 2.1 & 0.3 & 5 & 12 & 0.3 & 43.2 & 19.4 & 0.0 & 19.4 \\
\hline Total & & - & - & - & - & - & - & - & - & 70.5 & 31.7 & 342 & 374 \\
\hline \multirow[t]{2}{*}{ Future } & Permanent & 1.5 & 0.7 & 7 & 2.1 & 1 & 0 & 0 & 0 & 14.7 & 6.6 & 0.0 & 6.6 \\
\hline & Seasonal & 1.5 & 0.7 & 7 & 2.1 & 0.3 & 0 & 0 & 0 & 4.4 & 2.0 & 0.0 & 2.0 \\
\hline Total & & - & - & - & - & - & - & - & - & 19.1 & 8.6 & 0.0 & 8.6 \\
\hline
\end{tabular}


In MY 2008-09, not all households and facilities around the lake had septic discharge to the lake, because a large part of the shoreline was served by the sanitary sewer and many residences were a long distance from the lake. During MY 2008-09, it was estimated that 15 residences on the southwest shore were not served by the sanitary sewer and, therefore, potentially were not affecting the lake. Based on the 2000 census, the average household size for Mercer was 2.1 persons (ePodunk, Inc., 2007), and, therefore, this occupancy was used for these residences. It was assumed that about half of the residents living around the lake are permanent residents and half are seasonal or spend about 30 percent of the year in their lakeshore residences. The number of capita years was then calculated by multiplying the number of residences by the number of persons per household by the fraction of the year occupied; a total of 19 capita years during MY 2008-09 (table 10). During MY 2008-09, the annual phosphorus load contributed by septic inputs was estimated to be about $9 \mathrm{lb}$ (tables 9 and 10).

\section{Release of Phosphorus from Lake Sediments}

Three types of information are needed to estimate how much phosphorus may be released from the sediments of the lake: the area from which phosphorus is being released, the aerobic or anaerobic characteristics of the sediment surface, and the rate of phosphorus release. It was assumed that phosphorus was released only from areas greater than $6.5-\mathrm{ft}$ deep, because these areas typically accumulate organic sediment. It is important to determine where and how long the sediment interface is anaerobic, because phosphorus release is typically much higher during anaerobic conditions than during aerobic conditions. The dates when the sediment interface was anaerobic and the area of anaerobic sediment were estimated from the dates and depths at which a dissolved oxygen concentration of $0.5 \mathrm{mg} / \mathrm{L}$ or less was found in the profiles collected in the deepest areas of the lake. The sediment interface was typically anaerobic from about June 15 to about September 10, and typically below about $20 \mathrm{ft}$ (fig. 5). The areas of aerobic and anaerobic conditions are given in table 11 .

Rates of phosphorus release from the aerobic and anaerobic sediments in Mercer Lake were estimated from 12 sediment cores collected from the lake (figs. 2 and $4 A$ ) and analyzed by the WSLH. Daily aerobic-release rates ranged from $-1.93 * 10^{-8} \mathrm{lb} / \mathrm{ft}^{2}$ (removal of phosphorus from the water column) to $1.58 * 10^{-8} \mathrm{lb} / \mathrm{ft}^{2}$, with an average aerobic release rate of $4.94 * 10^{-9} \mathrm{lb} / \mathrm{ft}^{2}$ (table 12 ). Daily anaerobic-release rates ranged from $1.38^{*} 10^{-7} \mathrm{lb} / \mathrm{ft}^{2}$ to $4.33^{*} 10^{-7} \mathrm{lb} / \mathrm{ft}^{2}$, with an average anaerobic release rate of $2.77 * 10^{-7} \mathrm{lb} / \mathrm{ft}^{2}$. The anaerobic release rate was about 100 times greater than the aerobic release rate, and the aerobic release rate was not much different than the release rate from a tube analyzed with no sediment in it (blank).
The estimated amount of phosphorus released from the sediments of Mercer Lake was $26.3 \mathrm{lb}$ from May 1 through September (table 11; $3.5 \mathrm{lb}$ from aerobic sediments and $22.7 \mathrm{lb}$ from anaerobic sediments). Given the very low phosphorus release rate from the aerobic sediments, the assumption that phosphorus was not released from sediment shallower than $6.5 \mathrm{ft}$ was not very important. The amount of phosphorus released before May 1 and after September 30 is expected to be very low, because the water immediately above the sediments is typically aerobic when the lake is well mixed and release rates decrease when the water temperature is cool during fall, winter, and spring (James and Barko, 2004); therefore, the annual input of phosphorus from the sediments of the lake is estimated to be $26.3 \mathrm{lb}$.

\section{Surface-Water Outflow}

Phosphorus is discharged from Mercer Lake into the Little Turtle River through the Mercer Lake Outlet. Total phosphorus concentrations in the 34 samples collected at the outlet during the 2-year study period ranged from 0.012 to $0.034 \mathrm{mg} / \mathrm{L}$ (fig. $13 \mathrm{C}$ ), and the flow-weighted-average concentration was $0.019 \mathrm{mg} / \mathrm{L}$. Daily phosphorus loads were computed with GCLAS and summed to obtain annual totals. The total phosphorus output through the Mercer Lake Outlet was $271 \mathrm{lb}$ in MY 2008 and $214 \mathrm{lb}$ in MY 2009 (table 9).

\section{Phosphorus-Budget Summary}

\section{MY 2008-09}

During MY 2008-09, the average annual input of phosphorus to Mercer Lake was $340 \mathrm{lb}$ (table 9), of which $313 \mathrm{lb}$ came from external sources ( 92.3 percent) and $26.3 \mathrm{lb}$ came from the sediments in the lake ( 7.7 percent). The largest external source of phosphorus to the lake was from the Little Turtle Inlet, which delivered about 47 percent of the total load (fig. 21) compared with about 67 percent of the water input (fig. 18). The next largest contribution was from the near-lake area including much of the town and monitored storm drain, which delivered about 17 percent of the total phosphorus load, compared to only 4.6 percent of the water input. Contributions from precipitation and groundwater accounted for about 7 and 12 percent of the total load, respectively, while septic systems accounted for 2.5 percent of the total load. Phosphorus loading in MY 2009 was about 15 percent less than that in MY 2008 because the continuing drought reduced most of the inputs except that from Grand Portage Lake.

The average annual export of phosphorus to the Little Turtle River was $243 \mathrm{lb}: 271 \mathrm{lb}$ in MY 2008 and $214 \mathrm{lb}$ in MY 2009. Therefore, on average, about 70 percent of the external phosphorus load to the lake is exported out of the 
Table 11. Estimated areas of aerobic and anaerobic sediment below 6.5 feet in Mercer Lake, Iron County, Wis., and estimated sediment phosphorus release from May 1 to September 30.

[ $\mathrm{ft}^{2}$, square feet; lb, pounds; NA, not applicable]

\begin{tabular}{lccccc}
\hline Date & $\begin{array}{c}\text { Aerobic area } \\
\left.\mathbf{( f t}^{2}\right)\end{array}$ & $\begin{array}{c}\text { Anaerobic } \\
\mathbf{a r e a} \\
\left(\mathbf{f t}^{2}\right)\end{array}$ & $\begin{array}{c}\text { Aerobic } \\
\text { release } \\
(\mathbf{l b})\end{array}$ & $\begin{array}{c}\text { Anaerobic } \\
\text { release } \\
(\mathbf{l b})\end{array}$ & $\begin{array}{c}\text { Total release } \\
(\mathbf{l b})\end{array}$ \\
\hline May 1-June 14 & $5,210,000$ & 0 & 1.1 & 0.0 & 1.1 \\
June 15-Sept. 10 & $4,290,000$ & 922,000 & 1.9 & 22.7 & 24.6 \\
Sept. 11-Sept. 30 & $5,210,000$ & 0 & 0.5 & 0.0 & 0.5 \\
\hline Total & NA & NA & 3.5 & 22.7 & 26.3 \\
\hline
\end{tabular}

Table 12. Summary of estimated rates of phosphorus release from the sediments of Mercer Lake, Iron County, Wis.

[Locations of all sites are shown in figure $2 ; \mathrm{lb} / \mathrm{ft}^{2} / \mathrm{d}$, pounds per square foot per day; $\mathrm{R}^{2}$, coefficient of variation; NA, not applicable]

\begin{tabular}{|c|c|c|c|c|}
\hline Site number & $\begin{array}{l}\text { Replicate } \\
\text { identifier }\end{array}$ & $\begin{array}{l}\text { Aerobic or } \\
\text { anaerobic }\end{array}$ & $\begin{array}{l}\text { Release rate } \\
\qquad\left(\mathrm{lb} / \mathrm{ft}^{2} / \mathrm{d}\right)\end{array}$ & $\begin{array}{c}\text { Regression fit } \\
\text { from laboratory } \\
\text { results } \\
\left(\mathbf{R}^{2}\right)\end{array}$ \\
\hline s1 & A & Aerobic & $1.19 \mathrm{E}-08$ & 0.94 \\
\hline s1 & B & Aerobic & $1.06 \mathrm{E}-08$ & 0.99 \\
\hline s2 & A & Aerobic & $-1.93 \mathrm{E}-08$ & 0.96 \\
\hline s2 & $\mathrm{B}$ & Aerobic & $1.52 \mathrm{E}-08$ & 0.94 \\
\hline s3 & $\mathrm{A}$ & Aerobic & $-6.76 \mathrm{E}-09$ & 0.99 \\
\hline s3 & B & Aerobic & $1.58 \mathrm{E}-08$ & 0.96 \\
\hline s4 & A & Aerobic & $6.96 \mathrm{E}-09$ & 0.52 \\
\hline s4 & B & Aerobic & 5.12E-09 & 0.73 \\
\hline $\mathrm{s} 1$ & $\mathrm{C}$ & Anaerobic & $2.76 \mathrm{E}-07$ & 0.99 \\
\hline s1 & $\mathrm{D}$ & Anaerobic & $1.38 \mathrm{E}-07$ & 0.98 \\
\hline s2 & $\mathrm{C}$ & Anaerobic & 4.33E-07 & 0.97 \\
\hline s2 & $\mathrm{D}$ & Anaerobic & $2.61 \mathrm{E}-07$ & 0.96 \\
\hline Average & NA & Aerobic & 4.94E-09 & NA \\
\hline Average & NA & Anaerobic & $2.77 \mathrm{E}-07$ & NA \\
\hline Blank-No sediment & NA & Aerobic & $-6.76 \mathrm{E}-09$ & 0.22 \\
\hline
\end{tabular}


Phosphorus loading: 2-year average (340 pounds)

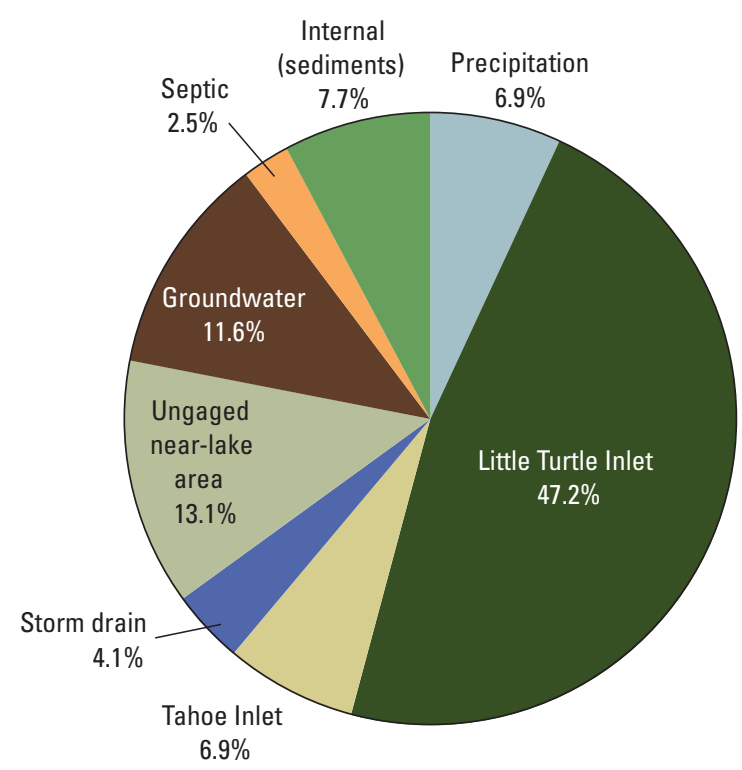

\section{Phosphorus loading: typical year (475 pounds)}

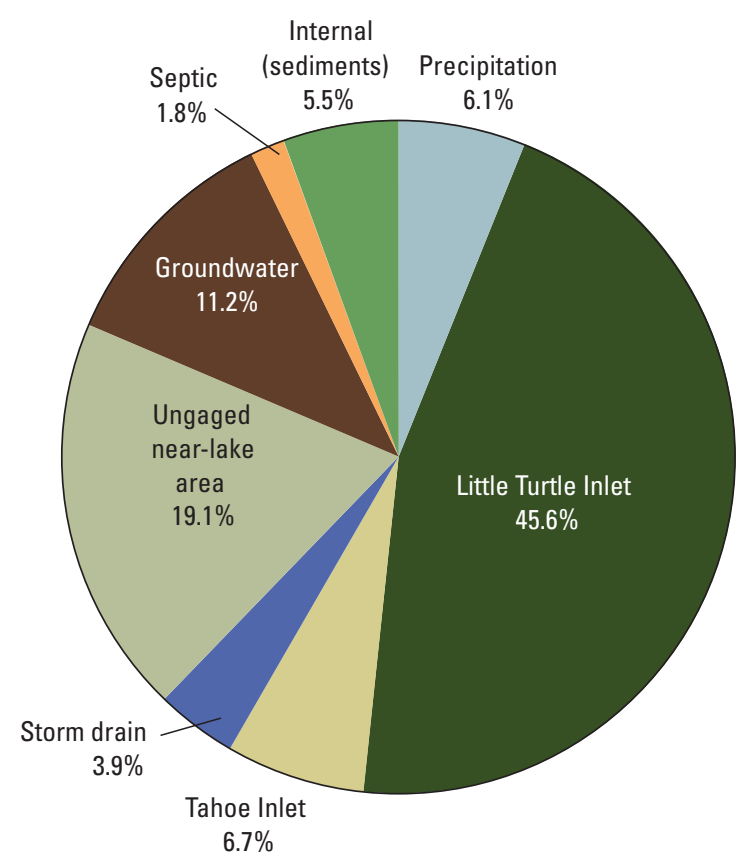

Figure 21. Phosphorus budgets for Mercer Lake, Iron County, Wis., for monitoring years 2008-09 and for typical hydrologic conditions.

lake. About 30 percent of the external phosphorus entering the lake is retained in the lake sediments, part of which may be released to the water column in the future. Lakes normally accumulate phosphorus in their bottom sediment; therefore, phosphorus inputs exceed phosphorus losses in most lakes (Graneli, 1999). A prolonged period when phosphorus exports exceed inputs would indicate that phosphorus inputs from the watershed have decreased and that phosphorus concentrations in the lake should decrease.

\section{Typical Hydrology}

The phosphorus loading in MY 2008-09 represents what occurred during a series of dry years. To determine phosphorus loading to the lake during more typical or average hydrologic conditions, loads were reestimated for each component of the phosphorus budget (table 9) on the basis of long-term average precipitation and flow values (described earlier) using the same phosphorus concentrations as estimated for MY 2008-09. No adjustments were made to inputs from septic systems and internal loading. With these assumptions, the total annual phosphorus load to Mercer Lake during typical hydrologic conditions is estimated to increase to about $475 \mathrm{lb}$ (table 9), which is an increase of about 40 percent from the average annual loading estimated for MY 2008-09, compared to an increase in water inputs of about 38 percent.

\section{Prior to 1965 with Typical Hydrology}

Phosphorus loading to Mercer Lake in MY 2008-09, even after compensating for the dry conditions, is expected to be less than it was prior to when there were more septic systems around the lake (prior to 1965) and when some sewage effluent may have been retained in the lake (1965-95). Prior to 1965 , it is expected that phosphorus contributions from septic systems and the town were much higher. Around 1965, 65 homes, 6 resorts, and a church were located on the shoreline of Mercer Lake, all with septic systems (Wisconsin Department of Natural Resources, 1970). If it is assumed that: 75 percent of the homes were nonpermanent (living on the lake 30 percent of the year), the average household size was 2.1 persons (ePodunk, Inc., 2007), each resort was occupied by 12 people for 30 percent of the year, and that septic systems were less efficient than they were in MY 2008-09 ( $S_{R}$ coefficient of 0.5 ), then the total estimated load from septic systems was $65 \mathrm{lb}$ (table 10). In addition, prior to 1965 , effluent from many of the residences farther from the lake probably reached the lake through pipes and overland runoff. The amount of phosphorus from these residences is very difficult to estimate. If it is assumed that their export is equivalent to 25 percent of the phosphorus that was discharged from the sewage treatment plant when it first opened in 1965 $(37,400 \mathrm{gal} / \mathrm{d}$ at a concentration of $10 \mathrm{mg} / \mathrm{L}$; R. Gothblad, 
Wisconsin Department of Natural Resources, written commun. 1975, "Mercer Sewage Treatment Plant-24-hour Survey Report"), then it is estimated that there was an additional source of $285 \mathrm{lb}$ of phosphorus (table 10). Therefore, prior to 1965 , septic systems and sewage effluent may have contributed about $350 \mathrm{lb}$ of phosphorus to the lake (table 10). If it is assumed that loadings from all of the other sources were similar to those estimated for MY 2008-09, then during typical years prior to 1965 , the total annual load of phosphorus would have been $816 \mathrm{lb}$ (table 9).

\section{5 to 1995 with Typical Hydrology}

From 1965 to 1995, most of the sewage from the residences around Mercer Lake was treated by the newly constructed sewage treatment plant; however, households west of the Little Turtle River were not included in this system. During this time, about 53 homes and 5 resorts were in the untreated area immediately around the lake (Wisconsin Department of Natural Resources, 1970). If it is assumed that: 75 percent of these homes were nonpermanent (living on the lake 30 percent of the year), the average household size was 2.1 persons, each resort was occupied by 12 people for 30 percent of the year, and that septic systems had a similar efficiency to that estimated for MY 2008-09 ( $S_{R}$ coefficient of 0.7), then the total estimated load from septic systems is estimated to have been about $32 \mathrm{lb}$ (table 10). During this time, effluent from the sewage treatment plant passed through a 3,000-ft long pipe laid along the bottom of the lake and discharged into Mercer Lake near its Outlet. It was believed that some of the effluent from the plant was not leaving the lake and may have been affecting water quality. The amount of phosphorus discharged into the lake is very difficult to estimate. To estimate the potential input from this discharge, it was assumed that 0,10 , and 25 percent of the total effluent discharged from the sewage treatment plant was retained in the lake. During 1965-95, about 37,400-52,500 gal/d (average of about $45,000 \mathrm{gal} / \mathrm{d}$ ) of effluent with a phosphorus concentration of about $10 \mathrm{mg} / \mathrm{L}$ was released from the sewage treatment plant (Wisconsin Department of Natural Resources, written commun., 1995). This equates to an annual average discharge of phosphorus of about 1,370 lb. Therefore, about $32 \mathrm{lb}$ of phosphorus would be added to the lake from septic systems and sewage treatment discharge with 0 percent of the effluent retained in the lake, $169 \mathrm{lb}$ of phosphorus added with 10 percent retained in the lake, and $374 \mathrm{lb}$ of phosphorus added with 25 percent retained in the lake (table 10). If it is assumed that loadings from all of the other sources were similar to those estimated for typical hydrologic years around MY 2008-09, then during typical hydrologic years during 1965-95, the total annual load of phosphorus would have been between 498 and $840 \mathrm{lb}$, depending on how much sewage treatment plant effluent was retained in the lake (table 9).

\section{Future with Typical Hydrology}

As of 2012, there are no immediate plans to add sewer lines to the residences on the southwest side of the lake; therefore, the amount of phosphorus from septic systems should remain similar to that estimated for MY 2008-09 ( $8.6 \mathrm{lb}$; table 10$)$. There are, however, plans to try to reduce the amount of runoff from stormwater reaching the lake as part of the Mercer Infrastructure Improvement Project, which includes highway and stormwater improvements, and other activities in the town of Mercer (Ayres and Associates, 2010). Ayers and Associates applied the Windows Source Loading and Management Model (WinSLAMM) to estimate current inputs of phosphorus and sediment to Mercer Lake from the area near the town of Mercer and to estimate how these inputs could be modified with various best management practice alternatives. WinSLAMM is a watershed model that is commonly used to estimate runoff volumes and loads from urban areas (Pitt and Voorhees, 1993). Ayers and Associates (2010) estimated that with existing (2010) land use, $50.4 \mathrm{lb}$ of phosphorus should be discharged to surface waters near from the area near the town of Mercer, and if anticipated changes in land use associated with Mercer Infrastructure Improvement Project are included, this discharge of phosphorus should increase to about $52.6 \mathrm{lb}$. Ayers and Associates (2010) also estimated that, with the installation of various best management practices, this discharge of phosphorus could be reduced by 36 percent. For this same area near the town, based on the information in table 9 , it was estimated in this study that this area should contribute about $74.8 \mathrm{lb}$ of phosphorus (input from the storm drain and 80 percent of the contributions from the ungaged near-lake area) during typical hydrologic conditions. Therefore, if the inputs from both of these areas were reduced by 36 percent, then the inputs from the storm drain would be $11.9 \mathrm{lb}$ and the total from the ungaged near-lake area would be $57.7 \mathrm{lb}$ (table 9). If it is assumed that loading from all of the other sources was similar to that estimated for typical hydrologic years around MY 2008-09, then during typical years after the Mercer Infrastructure Improvement Project is completed and the various best management practices are installed, the total annual load of phosphorus would decrease to about $435 \mathrm{lb}$ (table 9). In addition to highway improvements, additional development is expected around Mercer Lake. Much of this development is expected in areas that do not drain directly to the lake; therefore, the development should not affect loading to the lake. In addition, if areas draining to the lake are developed and development is performed as required by Wisconsin State law, then runoff and nutrient loading to the lake should not increase. 


\section{Simulated Changes in Water Quality in Response to Changes in Phosphorus Loading}

Empirical eutrophication models that relate phosphorus loading to specific water-quality characteristics can be used to determine how natural (climate driven) and anthropogenic changes in phosphorus loading could modify the water quality of Mercer Lake. These models were developed on the basis of comparisons between hydrologic and phosphorus loading determined for many different lake systems and specific measures describing lake water quality, such as near-surface phosphorus and chlorophyll $a$ concentrations, and Secchi depth (Vollenweider, 1975; Canfield and Bachmann, 1981; Reckhow and Chapra, 1983; Cooke and others, 1993; Panuska and Kreider, 2003). One empirical model that has been shown to be good at predicting phosphorus concentrations of lakes in Wisconsin is the Canfield and Bachman (1981) natural-lake model (Robertson and others, 2002, 2005; Robertson, Rose, and Juckem, 2009; Robertson, Rose, and Fitzpatrick, 2009; Robertson and Rose, 2008). Therefore, the Canfield and Bachman natural-lake model (1981; equation 6) was applied to Mercer Lake to determine how changes in phosphorus loading should affect phosphorus concentrations in the lake:

$$
\begin{aligned}
& \text { Total Phosphorus } \\
& \text { Concentration }(\mathrm{mg} / \mathrm{L})
\end{aligned}=\frac{L / 1000}{0.305 * Z\left(0.162 \times(L / Z)^{0.458}+1 / \tau\right)}
$$

where $L$ is the annual phosphorus-loading rate (in $\mathrm{mg} / \mathrm{m}^{2}=$ $\mathrm{lb} /$ acre $\mathrm{x}$ 112.07), $Z$ is the mean depth of the lake (in feet), and $\tau$ is the residence time of the water in the lake (in years). In this application, outputs from the model when the average annual hydrology and phosphorus loadings measured in MY 2008-09 were used as inputs were used as a base case (Base) for comparisons with other basinwide changes in loadings (tables 8 and 9). Outputs from the model when the hydrology and phosphorus loadings for typical hydrologic conditions were used as inputs were used as a base case (Reference) for all other comparisons.

The total phosphorus concentrations predicted with the Canfield and Bachman model were then used to predict chlorophyll $a$ concentrations and Secchi depths through the use of Carlson's (1977) TSI equations (equations 1-3). In other words, the chlorophyll $a$ concentrations and Secchi depths that yielded a similar TSI value as that computed from the predicted total phosphorus concentration were computed. There are no true calibration factors when Carlson's TSI equations are used to estimate chlorophyll $a$ concentrations and Secchi depths in this manner; therefore, the output was adjusted to account for model biases by adjusting the results by the percentage of bias in the results for the base-case (Base) scenario.

\section{Modeling Approach}

To estimate how the water quality of Mercer Lake should respond to changes in phosphorus loading, 17 scenarios were simulated with the Canfield and Bachman model and Carlson TSI equations (table 13 and fig. 22). Scenario 1 simulated the average conditions for MY 2008-09. Eight simulations (2-9) were used to determine the general response of the lake to basinwide changes in external phosphorus loading: simulated decreases in external phosphorus loading by 75,50 , and 25 percent and increases in external phosphorus loading by 25, 50, 75, 100, and 200 percent. External loading excludes phosphorus loading from the sediment. Internal phosphorus loading from the sediments is not expected to change quickly in response to changes in external loading and, therefore, was not modified in scenarios 2-9. Scenario 1 established a base condition (concentration) to which results from the other basinwide changes can be compared. Although the models can simulate the effects of dramatic reductions in phosphorus loading, such as a 75 percent reduction, this type of reduction may not be possible given that much of the phosphorus loading is coming from a relatively pristine upstream watershed, groundwater, and precipitation.

Eight scenarios (10-17) were then used to determine how changes in phosphorus loading caused by natural (hydrologic) and anthropogenic changes could have modified in the past or could modify the water quality of the lake in the future. Scenario 10 which had the hydrology and phosphorus loadings for typical hydrologic conditions is labeled as the "Reference" in figure 22. Three scenarios (10-12) were used to simulate the effects of changes in hydrology and the effects of internal phosphorus loading from the sediments. Four scenarios (13-16) were used to simulate the response of the lake to historical changes in phosphorus loading. In scenario 13, the response of the lake to inputs for typical hydrologic conditions prior to 1965 was simulated. In scenarios 14-16, responses of the lake to inputs for 1965-95 with various levels of sewage treatment plant effluent retained in the lake were simulated. In scenario 17, the models were used to predict the response of the lake to the inputs estimated during typical years after the Mercer Infrastructure Improvement Project is completed and the proposed best management practices are installed.

Four types of data are required as input into the Canfield and Bachman model (table 13): water-quality data (from table 5), morphometric data (mean depth), hydrologic data (residence time), and nutrient-loading data (from table 9). Although the loading data used as input to these models are summarized for the entire year, these models simulate water quality only for the growing season (May-September); therefore, the water-quality data in table 5 were used for comparisons. 
Table 13. Estimated water quality in Mercer Lake, Iron County, Wis., in response to various phosphorus-loading scenarios based on the Canfield and Bachman natural-lake model (1981) and Carlson (1977) trophic-state-index equations.

[lb, pounds; ft, feet; mg/L, milligrams per liter; $\mu \mathrm{g} / \mathrm{L}$, micrograms per liter]

\begin{tabular}{|c|c|c|c|c|c|c|c|c|c|}
\hline Simulations & $\begin{array}{l}\text { Scenario } \\
\text { number }\end{array}$ & $\begin{array}{c}\text { Annual } \\
\text { phosphorus } \\
\text { load } \\
\text { (lb) }\end{array}$ & $\begin{array}{c}\text { Water } \\
\text { elevation } \\
\text { above an } \\
\text { arbitrary } \\
\text { datum } \\
\text { (ft) }\end{array}$ & $\begin{array}{l}\text { Surface area } \\
\text { (acres) }\end{array}$ & $\begin{array}{l}\text { Mean } \\
\text { depth } \\
(\mathrm{ft})\end{array}$ & $\begin{array}{l}\text { Residence } \\
\text { time } \\
\text { (years) }\end{array}$ & $\begin{array}{c}\text { Predicted total } \\
\text { phosphorus } \\
\text { concentration } \\
(\mathrm{mg} / \mathrm{L})\end{array}$ & $\begin{array}{c}\text { Predicted } \\
\text { chlorophyll a } \\
\text { concentration } \\
(\mu \mathrm{g} / \mathrm{L})\end{array}$ & $\begin{array}{l}\text { Predicted } \\
\text { Secchi } \\
\text { depth } \\
\text { (ft) }\end{array}$ \\
\hline \multicolumn{10}{|c|}{ General response } \\
\hline \multicolumn{10}{|l|}{ Percent change in external phosphorus load } \\
\hline-75 percent & 2 & 105 & 86 & 179 & 10.0 & 0.46 & 0.008 & 0.8 & 27.0 \\
\hline-50 percent & 3 & 183 & 86 & 179 & 10.0 & 0.46 & 0.013 & 1.6 & 16.5 \\
\hline-25 percent & 4 & 261 & 86 & 179 & 10.0 & 0.46 & 0.018 & 2.5 & 12.1 \\
\hline 0 percent (Base) & 1 & 340 & 86 & 179 & 10.0 & 0.46 & 0.023 & 3.5 & 9.7 \\
\hline+25 percent & 5 & 418 & 86 & 179 & 10.0 & 0.46 & 0.027 & 4.5 & 8.1 \\
\hline+50 percent & 6 & 496 & 86 & 179 & 10.0 & 0.46 & 0.031 & 5.6 & 7.1 \\
\hline+75 percent & 7 & 575 & 86 & 179 & 10.0 & 0.46 & 0.035 & 6.7 & 6.3 \\
\hline+100 percent & 8 & 653 & 86 & 179 & 10.0 & 0.46 & 0.039 & 7.8 & 5.6 \\
\hline+200 percent & 9 & 967 & 86 & 179 & 10.0 & 0.46 & 0.053 & 12.3 & 4.1 \\
\hline \multicolumn{10}{|c|}{ Specific natural and anthropogenic scenarios } \\
\hline Typical hydrology (Reference) & 10 & 475 & 86 & 179 & 10.0 & 0.32 & 0.024 & 3.8 & 9.2 \\
\hline MY 2008-09 (no internal loading) & 11 & 313 & 86 & 179 & 10.0 & 0.46 & 0.021 & 3.2 & 10.4 \\
\hline Typical hydrology (no internal loading) & 12 & 449 & 86 & 179 & 10.0 & 0.32 & 0.023 & 3.5 & 9.7 \\
\hline 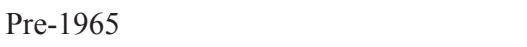 & 13 & 816 & 86 & 179 & 10.0 & 0.32 & 0.038 & 7.4 & 5.8 \\
\hline 1965-95 (0 percent retention) & 14 & 498 & 86 & 179 & 10.0 & 0.32 & 0.025 & 4.0 & 8.9 \\
\hline 1965-95 (10 percent retention) & 15 & 635 & 86 & 179 & 10.0 & 0.32 & 0.031 & 5.4 & 7.2 \\
\hline 1965-95 (25 percent retention) & 16 & 840 & 86 & 179 & 10.0 & 0.32 & 0.039 & 7.7 & 5.7 \\
\hline $\begin{array}{l}\text { Future scenario with use of best-manage- } \\
\text { ment practices }\end{array}$ & 17 & 435 & 86 & 179 & 10.0 & 0.32 & 0.022 & 3.4 & 9.9 \\
\hline
\end{tabular}


$\boldsymbol{A}$

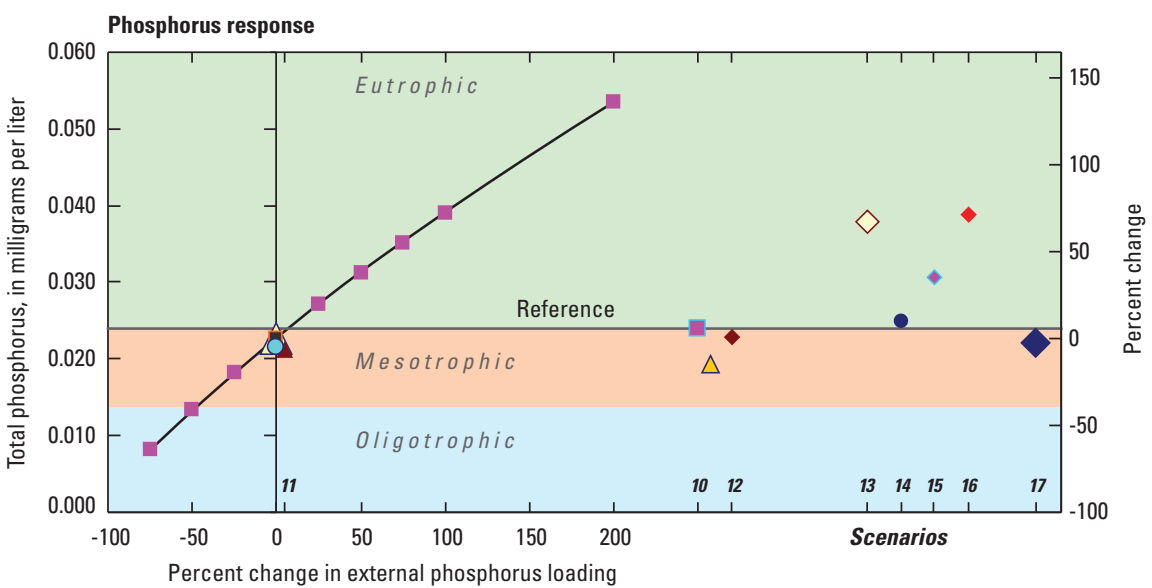

B

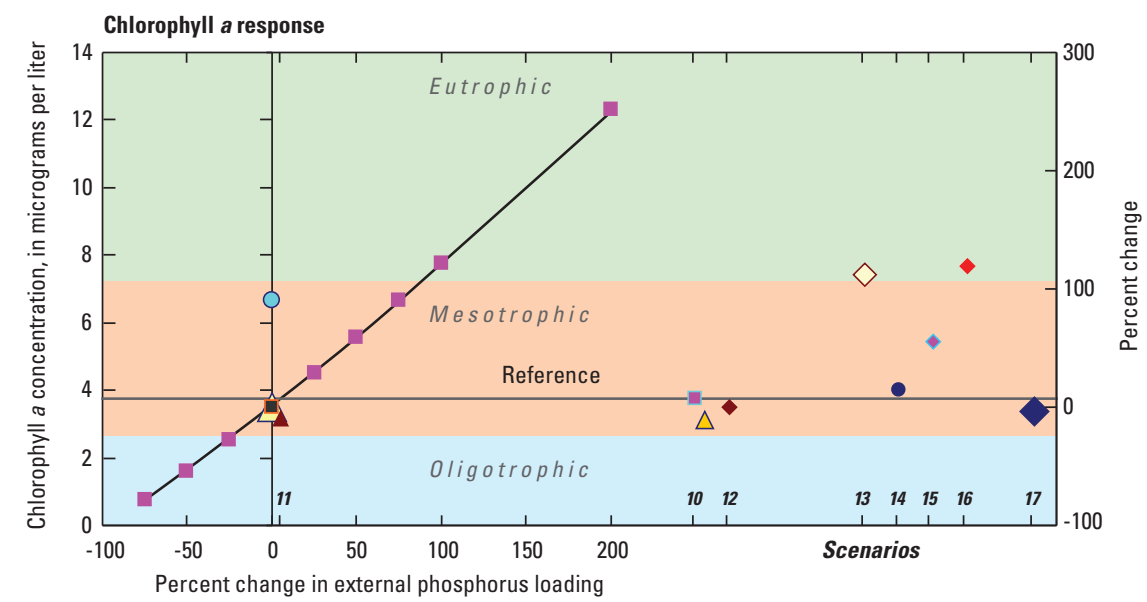

C

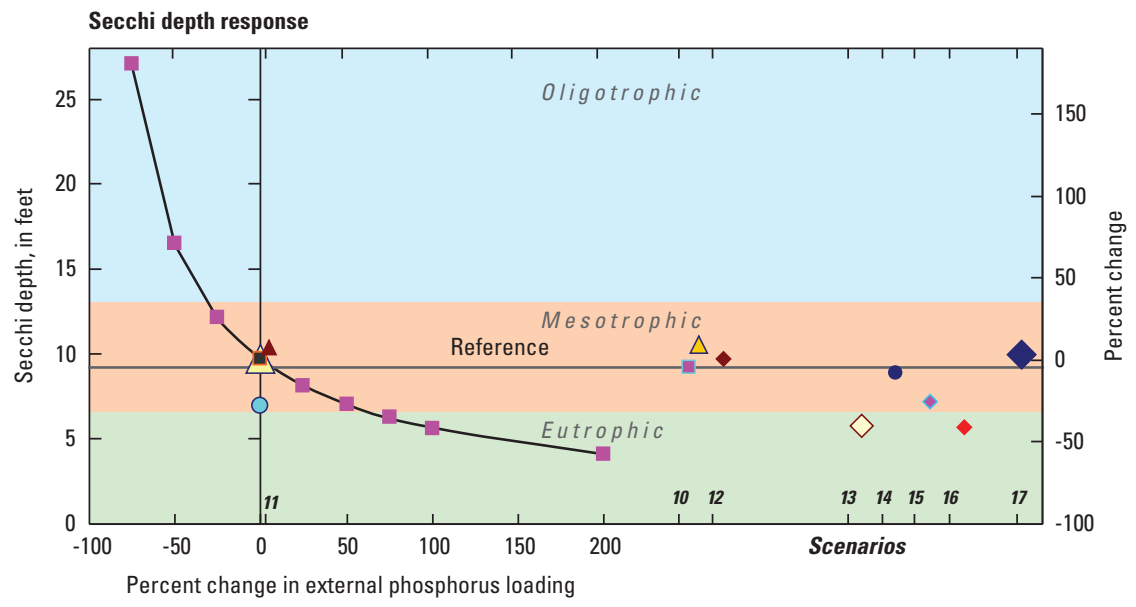

EXPLANATION

Measured water quality $\triangle$ Measured (2008-09)

$\triangle$ Measured typical hydrology (2006-10)

Simulations (with scenario numbers for 10-17)

$\bigcirc$ Directly simulated using eutrophication models $\diamond 13$ Pre 1965

1 Adjusted base simulation (2008-09)

2-g General response

- 10 Typical hydrology

- 14 1965-95 (0 percent retention)

- 15 1965-95 (10 percent retention)

- 16 1965-95 (25 percent retention)

A 11 Monitoring year 2008-09 (no internal loading)

- 12 Typical hydrology (no internal loading)

Figure 22. Measured and simulated summer-average near-surface concentrations of $A$, total phosphorus, $B$, chlorophyll $a$, and $C$, Secchi depths in Mercer Lake, Iron County, Wis., in response to various phosphorus-loading scenarios. 


\section{Verification and Adjustments for Model Biases}

The ability of the Canfield and Bachman (1981) model to simulate the changes in phosphorus concentrations in the lake (termed "in-lake concentrations") was evaluated by inputting the morphometry of the lake and the hydrologic and phosphorus loadings for MY 2008-09 into the model (equation 6) and simulating the average near-surface total phosphorus concentration. The simulated total phosphorus concentration for MY $2008-09(0.021 \mathrm{mg} / \mathrm{L}$; fig. $22 A)$ is similar to that measured in the lake $(0.023 \mathrm{mg} / \mathrm{L}$; table 5$)$. This similarity indicates that the model should accurately simulate the summer-average phosphorus concentrations in Mercer Lake in response to changes in phosphorus loading. Because of the small discrepancy in measured and simulated phosphorus concentrations, all of the simulated phosphorus concentrations were increased by 8 percent.

Determining how well the Carlson (1977) TSI equations simulate chlorophyll $a$ concentrations and Secchi depths in Mercer Lake was accomplished by comparing the measured values with those estimated with equations 2 and 3 using the TSI value based on the adjusted simulated total phosphorus concentration. Given a TSI value of 49.2 (from equation 1 with the adjusted simulated phosphorus concentration of $0.023 \mathrm{mg} / \mathrm{L}$ ), the unadjusted predicted chlorophyll $a$ concentration was $6.7 \mathrm{mg} / \mathrm{L}$ and the unadjusted predicted Secchi depth was $6.9 \mathrm{ft}$ (fig. $22 B$ and $C$ ). The measured chlorophyll $a$ concentration in MY 2008-09 was $3.5 \mathrm{mg} / \mathrm{L}$, which is less than that predicted with equation 2 . The measured Secchi depth in MY 2008-09 was $9.7 \mathrm{ft}$, which is greater than that predicted with equation 3 . The discrepancy in chlorophyll $a$ concentrations and Secchi depths indicates that measured chlorophyll $a$ concentrations are lower than expected, and the clarity measured in Mercer Lake is better than would be expected given the measured phosphorus concentrations. These discrepancies may have been caused by specific characteristics in Mercer Lake that differ from other lakes with similar phosphorus concentrations, such as the extensive macrophytes in the lake, algal growth on the macrophytes, structure of the food web, or the binding of phosphorus to iron to make the phosphorus less available for algae growth. Because of the large discrepancies in measured and simulated chlorophyll $a$ concentrations and Secchi depths, all of the simulated chlorophyll $a$ concentrations from equation 2 were decreased by 47 percent and the Secchi-depth values from equation 3 were increased by 40 percent.

\section{Response in Water Quality to Basinwide Changes in Phosphorus Loading}

On the basis of model simulations for basinwide changes in external phosphorus loading (scenarios 2-9; table 13), inlake phosphorus concentrations should have a relatively linear response to a linear change in loading (fig. 22A); however, on a percentage basis, the changes in in-lake phosphorus concentrations are about 20 percent smaller than the changes in external phosphorus loadings. For example, a 50-percent change in external phosphorus loading should cause about a 40-percent change in in-lake phosphorus concentrations. Given that much of the phosphorus loading to Mercer Lake is coming from a relatively pristine upstream watershed, reductions in loading of more than about 50 percent may not be possible.

Simulated summer-average chlorophyll $a$ concentrations also had a relatively linear response to changes in external phosphorus loading (fig. 22B); however, on a percentage basis, changes in chlorophyll $a$ concentrations are about 10-20 percent larger than the changes in external phosphorus loadings. For example, a 50-percent change in external phosphorus loading should cause about a 55- to 60-percent change in chlorophyll $a$ concentrations.

Simulated summer-average Secchi depths had a nonlinear response to changes in external phosphorus loading, with a much larger response to decreases in loading than to increases in loading (fig. 22C). For example, a 50-percent decrease in external phosphorus loading should cause about a 70-percent increase in Secchi depths, whereas a 50-percent increase in external phosphorus loading should cause only about a 27-percent decrease in Secchi depths.

\section{Response in Water Quality during Typical Hydrologic Conditions}

The region near Mercer Lake experienced very dry conditions during MY 2008-09, which resulted in hydrologic and nutrient loading to the lake being less than normal (tables 8 and 9); therefore, water-quality conditions during years with more typical hydrology may be different than those measured in MY 2008-09. Scenario 10 was used to determine how natural (climatic) changes such as phosphorus loading associated with more typical hydrology - rather than the atypical conditions during MY 2008-09-should affect water quality (labeled as "Reference" in fig. 22; table 13). With typical hydrologic conditions, the hydrologic and phosphorus inputs to the lake are expected to increase by about 40 percent (tables 9 and 13). On the basis of model simulations, this increase in water and phosphorus loading is expected to have very little effect on water quality: total phosphorus and chlorophyll $a$ concentrations may increase slightly and water clarity may decrease slightly (table 13 and fig. 22). The small change in water quality results from the small expected changes in phosphorus concentrations in the inflowing water. The simulated conditions were then compared with conditions measured in the lake from 2006 to 2010 , during which a range in hydrologic conditions occurred. During 2006-10, the average phosphorus concentration measured in the lake was $0.019 \mathrm{mg} / \mathrm{L}$, the average chlorophyll $a$ concentration was $3.1 \mathrm{mg} / \mathrm{L}$, and the average Secchi depth was $10.7 \mathrm{ft}$ (fig. 22). All of the conditions measured during 2006-10 were similar to those measured in 2008-09, also indicating that changes in hydrology have little effect on the trophic conditions in the lake. 


\section{Simulated Effects of Internal Phosphorus Loading}

Two scenarios (11 and 12, in comparison with scenarios 1 and 10, respectively) were used to determine the effects of internal phosphorus loading from the sediments on the water quality of the lake. Complete removal of the phosphorus loading from the sediments from scenarios 1 and 10 (26.3 lb decrease; about 6-8 percent of the total phosphorus budget, table 9) resulted in simulated in-lake near-surface phosphorus concentrations decreasing by only $0.001 \mathrm{mg} / \mathrm{L}$ in scenarios 11 and 12. These small decreases in phosphorus concentrations resulted in modest decreases in chlorophyll $a$ concentrations $(0.3 \mathrm{mg} / \mathrm{L})$ and modest increases in Secchi depths ( 0.5 to $0.7 \mathrm{ft}$ ) (table 13). Therefore, internal phosphorus loading in Mercer Lake has only a small effect on the present water quality of Mercer Lake and should have a small effect in the future if phosphorus loading to the lake is reduced.

\section{Response in Water Quality to Past and Future Anthropogenic Changes in the Watershed}

Responses in water quality to anthropogenic changes near Mercer Lake were simulated with typical hydrologic conditions, and the results of the models were compared with those of scenario 10 (labeled as "Reference" in fig. 22). Four scenarios (13-16) were used to simulate the response of the lake to historical phosphorus loading. In scenario 13, the response of the lake to the inputs estimated for typical hydrologic conditions prior to 1965 were simulated. Prior to 1965, phosphorus inputs from septic systems and other untreated systems were estimated to be $349 \mathrm{lb}$, or about $340 \mathrm{lb}$ more than in MY 2008-09 and represent about 43 percent of the total phosphorus budget (tables 9 and 10). This increase in loading resulted in simulated near-surface phosphorus concentrations increasing from $0.024 \mathrm{mg} / \mathrm{L}$ to $0.038 \mathrm{mg} / \mathrm{L}$, an increase of $0.014 \mathrm{mg} / \mathrm{L}$. This increase in phosphorus concentrations resulted in simulated chlorophyll $a$ concentrations increasing to $7.4 \mathrm{mg} / \mathrm{L}$ (an increase of $3.6 \mathrm{mg} / \mathrm{L}$ ) and simulated Secchi depths decreasing to $5.8 \mathrm{ft}$ (a decrease of $3.4 \mathrm{ft}$ ) (table 13). Therefore, prior to 1965 , water quality should have been much worse than in recent years, and the lake would have been classified as eutrophic.

In scenarios 14-16, the response of the lake to the inputs estimated for years with typical hydrologic conditions between 1965 and 1995 were simulated with various levels of sewage treatment plant effluent being retained in the lake. In these simulations, phosphorus inputs from the septic systems $(31.7 \mathrm{lb})$ were estimated to be higher than during the study period by $23.1 \mathrm{lb}$ and inputs from sewage treatment plant effluent varied from 0 to $342 \mathrm{lb}$ (tables 9 and 10). This increase in loading resulted in simulated near-surface phosphorus concentrations increasing from $0.024 \mathrm{mg} / \mathrm{L}$ to between 0.025 and $0.039 \mathrm{mg} / \mathrm{L}$, depending on how much effluent was retained in the lake. These increases in phosphorus concentrations resulted in simulated chlorophyll $a$ concentrations increasing to between 4.0 and $7.7 \mathrm{mg} / \mathrm{L}$ and simulated Secchi depths decreasing to between 8.9 and $5.7 \mathrm{ft}$ (table 13). Therefore, between 1965 and 1995, water quality in the lake could have been anywhere between the conditions estimated prior to 1965 , if 25 percent of the sewage treatment plant effluent was retained in the lake, and what was expected during typical hydrologic conditions around MY 2008-09, if no sewagetreatment-plant effluent was retained in the lake.

In scenario 17, the response of the lake to the inputs estimated during typical years after the Mercer Infrastructure Improvement Project is completed and the proposed best management practices are installed was simulated. If the future construction is done with the proposed best management practices, the total annual load of phosphorus should decrease by about $40 \mathrm{lb}$ to about $435 \mathrm{lb}$ (tables 9 and 13). This $40-1 \mathrm{~b}$ decrease in loading resulted in simulated near-surface phosphorus concentrations decreasing from $0.024 \mathrm{mg} / \mathrm{L}$ to $0.022 \mathrm{mg} / \mathrm{L}$. This decrease in the average phosphorus concentration resulted in simulated chlorophyll $a$ concentrations decreasing to $3.4 \mathrm{mg} / \mathrm{L}$ and simulated Secchi depths increasing to $9.9 \mathrm{ft}$ (table 13). Therefore, if Mercer Infrastructure Improvement Project and the proposed best management practices are completed as proposed, the water quality could improve slightly.

TSI values based on near-surface concentrations of total phosphorus and chlorophyll $a$, and on Secchi depths, indicate that Mercer Lake is usually classified as borderline mesotrophic-eutrophic with respect to phosphorus concentrations and mesotrophic with respect to chlorophyll $a$ concentrations and water clarity (fig. 10). On the basis of the model simulations (fig. 22), the lake was probably more productive prior to 1995 , especially prior to 1965 , and may have been classified as eutrophic based on all three trophic state variables. Model results also indicate that if construction around the lake in the future is done as proposed, the water quality of the lake should not change very much and may improve slightly if the best management practices are installed as they are being proposed; therefore, the lake should remain being classified as borderline mesotrophic-eutrophic with respect to total phosphorus concentrations and mesotrophic with respect to chlorophyll $a$ concentrations and water clarity.

\section{Importance of Internal Phosphorus Loading to Lake Productivity}

When the deep water of productive lakes becomes anaerobic, the rate of phosphorus release from the sediments in these areas is often greatly accelerated. Typically, in deep dimictic lakes that remain stratified throughout summer, such as Minocqua Lake in north-central Wisconsin (Garn and others, 2010), phosphorus from internal loading is trapped in the hypolimnion during most of the summer and released into the shallow water primarily at fall overturn, which results in nearsurface phosphorus concentrations decreasing or changing 
very little as summer progresses . But in polymictic lakes, such as many shallow lakes like Butternut Lake also in northcentral Wisconsin (Robertson and others, 2008), phosphorus released from the sediments is not trapped in the bottom of the lake but is intermittently released to the shallow water throughout summer, which results in near-surface phosphorus concentrations increasing as summer progresses. Mercer Lake is a relatively shallow lake with an overall Osgood Index of 3.6 (table 3); therefore, the lake might be expected to be polymictic. Given that Mercer Lake has two basins, only part of its surface area is exposed to the wind at any time. The Osgood Index of the East Basin of the lake is 6.1 and the West Basin is 4.2 , which indicate both basins may be between these two categories and may mix intermittently. Prior to this study, it was uncertain whether Mercer Lake acted like a dimictic or polymictic lake. Based on results of this study, Mercer Lake acts as a deeper, dimictic lake in which the water remains stratified throughout most of the summer (fig. 5), which results in most of the phosphorus released from the sediments being trapped in the hypolimnion of the lake and not causing near-surface phosphorus concentrations to increase as summer progresses.

Although the phosphorus load to Mercer Lake has decreased as a result of mitigation efforts in the watershed (table 1), it was believed that the internal phosphorus load may delay the response of the lake to decreases in external phosphorus loading. Because Mercer Lake acts like a deep dimictic lake, contributions of phosphorus from internal loading during any given summer are relatively small (fig. 21) and, therefore, have minimal effect on that summer's productivity. Although nutrient loading to the lake may have been quite high because of septic and sewage treatment plant inputs (table 10) and may have increased the phosphorus content of the bottom sediments (table 6), the overall contribution from internal phosphorus loading is quite small (table 9), as demonstrated by the relatively low near-bottom phosphorus concentrations in late summer (fig. 8). Internal loading represents only approximately 6 percent of the total phosphorus load to the lake. Therefore, the phosphorus trapped in the sediments of the lake should have minimal effect on the changes in future phosphorus concentrations and should not delay the recovery or response in the productivity of the lake to decreases in nutrients from its watershed.

\section{Relative Importance of Natural and Anthropogenic Changes in the Watershed to Lake Productivity}

One purpose of this study was to understand how changes in water quality resulting from natural changes in hydrology and nutrient loading caused by changes in climate compare with changes in water quality caused by anthropogenic modifications to the watershed, such as historical changes caused by septic and sewage input and future changes that may result from modifications to the watershed. Based on the comparison of model results for MY 2008-09 (dry years) to results for years with typical hydrology and nutrient loading, it appears that the water quality of Mercer Lake changes very little in response to natural changes in hydrology. This predicted lack of response in water quality was also observed in the measured data from 2006 to 2010 when relatively extensive monitoring was conducted. Results from the eutrophication models indicate that changes in the water quality of Mercer Lake in response to changes in anthropogenic modifications to the watershed should be much larger than the changes caused by natural hydrologic variability. Results of the models indicate that the lake should have been eutrophic prior to 1965 with average near-surface phosphorus concentrations near $0.038 \mathrm{mg} / \mathrm{L}$, chlorophyll $a$ concentrations about $7 \mathrm{mg} / \mathrm{L}$, and Secchi depths about $6 \mathrm{ft}$. The predicted poorer water quality around 1965 agrees with the shallower Secchi depths estimated from Garrison's (2005) sediment core analysis (fig. 11); however, the magnitude of the change is more than estimated from that analysis. The difference in response based on the eutrophication models and the sediment core analyses may have resulted from a possible overestimation of the additional contributions of phosphorus from the other untreated systems (285 lb in table 10). Input from the other untreated systems could only be roughly estimated. Since 1965 , the results of both the eutrophication models and the sediment core analyses indicate that water quality should have gradually improved.

If the Mercer Infrastructure Improvement Project is done with the proposed best management practices and future development occurs with little increase in runoff and nutrient loading, then phosphorus loading to the lake should remain similar to that estimated in this study and the water quality of the lake should remain similar to that measured from 2006 to 2010. Future nutrient loading estimates from Ayers and Assoc. (2010) indicate that minor decreases in nutrient loading should occur as part of the Mercer Infrastructure Improvement Project, which included highway and stormwater improvements, as long as the construction is done with the proposed best management practices; therefore, little change in water quality in Mercer Lake is expected in 2010-20.

\section{Summary and Conclusions}

Mercer Lake is relatively shallow 179-acre drainage lake in north-central Wisconsin. Mercer Lake's watershed has gone through many changes since European settlers first arrived, including urban and industrial development and population growth. Residents felt that this development and past activities in the Mercer Lake watershed, such as historical wastewater discharges from septic systems, the municipal sewage treatment plant, lumber mill, and urban development, have affected the water quality of the lake. Over the past few years, many efforts were taken to improve the water quality of the lake, including removal of the lumber mill and diversion of 
all effluent from the sewage treatment plant away from the lake; however, it was uncertain what affects these actions had on water quality. Mercer Lake area residents and authorities would like to continue to try to improve the water quality of the lake; therefore, understanding the past, present, and future factors affecting water quality, especially the effects of wastewater discharges to the lake, is very important and was addressed in this report.

To provide a better understanding of the factors that affect the water quality of Mercer Lake, a detailed study of the lake and its watershed was done in monitoring years (MY) 2008-09 by the USGS in cooperation with the Mercer School District. The purposes of the study were to describe the water quality of the lake and the composition of its sediments; quantify the sources of water and phosphorus loading to the lake, including those associated with septic and municipal wastewater discharges; and evaluate the effects of changes in phosphorus inputs on the water quality of the lake. Waterquality data were collected in the lake during MY 2008-09 and compared with assembled historical data. Bottom sediments were used to describe historical water clarity and were analyzed for wastewater, industrial, and urban pollutants. Major water and phosphorus sources were measured directly, and minor sources were estimated to construct detailed water and phosphorus budgets for the lake. Lake eutrophication models were then used to simulate how the water quality of the lake should respond to past, present, and future changes in nutrient loading.

During MY 2008-09, the average summer near-surface concentration of total phosphorus was $0.023 \mathrm{mg} / \mathrm{L}$, indicating the lake is borderline meso-eutrophic, whereas the average summer chlorophyll $a$ concentration was $3.3 \mathrm{mg} / \mathrm{L}$ and Secchi depth was $10.4 \mathrm{ft}$, both indicating mesotrophic conditions. Based on sediment core analysis and limited in-lake monitoring data, water quality appears to have improved since a sewage treatment plant was constructed in 1965 and its discharge completely routed away from the lake in 1995. Based on sediment core analyses, the poorest water clarity and highest algal productivity in the lake occurred around 1965; however, the density of macrophytes was higher prior to and after 1965. Since 2000, when a more consistent monitoring program began, the water quality of the lake appears to have changed very little.

The bottom sediments had slightly elevated concentrations of several constituents associated with wastewater discharges from septic systems, the municipal sewage treatment plant, lumber mill, and urban runoff, and a few natural metals (such as iron). These elevated concentrations reflect modifications that have taken place in the watershed over the past 100 years. Although concentrations of several pollutants were elevated, none of the concentrations were much above the defined thresholds of concern.

During the 2-year detailed monitoring period, the Little Turtle Inlet contributed about 67 percent of the total water inflow, groundwater contributed about 17 percent, and near-lake inflow and precipitation contributed about
10 and 7 percent, respectively. The average residence time of water in the lakes was 0.46 years. Water leaves the lake primarily through the lake outlet (93 percent) or by evaporation (7 percent). MY 2008-09 were very dry years, and during years with typical hydrology, the total water input to the lake should increase by about 38 percent; however, the relative importance of each source should remain relatively similar.

Productivity in Mercer Lake should typically be limited by phosphorus; therefore, understanding the phosphorus input is important when management efforts to improve or prevent degradation in the lake water quality are considered. During MY 2008 and 2009, the total annual input of phosphorus was 364 and $315 \mathrm{lb}$, respectively. During these years, the largest sources of phosphorus were from Little Turtle Inlet (about 45 percent), near-lake drainage area containing the adjacent urban and residential developments (17 percent), groundwater (12 percent), Tahoe Inlet (7 percent), and precipitation (7 percent). During years with typical hydrology, the phosphorus input should increase by about 40 percent, to about $475 \mathrm{lb}$, and the relative importance of the near-lake drainage area should increase. Phosphorus inputs were also estimated for three periods:

1. Prior to 1965 , when there was no sewage treatment plant and inputs from septic systems and other untreated systems were thought to be about $340 \mathrm{lb}$ greater than in MY 2008-09 Phosphorus loading during years with typical hydrology was estimated to be about $815 \mathrm{lb}$.

2. Between 1965 to 1995, when some of the effluent from the new sewage treatment plant was retained in the lake (estimated to be between 0 to $342 \mathrm{lb}$ ). Phosphorus loading during years with typical hydrology was estimated to be between about 500 and $840 \mathrm{lb}$.

3. The future, when the Mercer Infrastructure Improvement Project is completed. Inputs should decrease by about $40 \mathrm{lb}$ if the best management practices are installed as proposed. Phosphorus loading during years with typical hydrology should be about $435 \mathrm{lb}$.

The Canfield and Bachman eutrophication model and Carlson TSI equations were used to predict changes in water quality of Mercer Lake that should occur with changes in phosphorus loading. A relatively linear response was found between external phosphorus loading and phosphorus and chlorophyll $a$ concentrations in the lake. On a percentage basis, the changes in phosphorus concentrations in the lake were about 20 percent smaller than the changes in external phosphorus loadings, whereas changes in chlorophyll $a$ concentrations were about 10-20 percent larger than the changes in phosphorus loadings. Secchi depths, which indicate water clarity, had a nonlinear response to a linear change in external phosphorus loading, with a larger response to decreases in loading than to increases in loading.

The eutrophication models were then used to predict what historical and future water quality in the lake was and would be like when phosphorus loading was different. Results 
indicated that the lake was negatively affected by the wastewater discharges. Prior to 1965, when there was no sewage treatment plant and inputs from the septic systems and other untreated systems were thought to be higher than in recent years, the lake should have been eutrophic, with average near-surface phosphorus concentrations near $0.038 \mathrm{mg} / \mathrm{L}$, chlorophyll $a$ concentrations about $7 \mathrm{mg} / \mathrm{L}$, and Secchi depths about $6 \mathrm{ft}$. The simulated degraded water quality agreed with the shallower Secchi depths estimated from the sediment core analysis; however, the magnitude of the change was more than that estimated from the sediment analysis. The models indicated that between 1965 and 1995, when some of the effluent from the new sewage treatment plant was retained in the lake, water quality could have been anywhere between the conditions estimated prior to 1965 and what was expected during typical hydrologic conditions around MY 2008-09, depending on the amount of sewage treatment plant effluent retained in the lake. The models also indicated that if the Mercer Infrastructure Improvement Project is conducted as proposed, with the best management practices, water quality could improve slightly from that measured during 2006-10.

Because of the limited phosphorus presently input into Mercer Lake, increases in phosphorus loading could have a large effect on water quality. Therefore, management actions to minimize future phosphorus input into Mercer Lake are likely to greatly benefit water quality. Although the phosphorus load has decreased as a result of mitigation efforts in the watershed, especially a decrease in the input from septic and municipal wastewater, it was believed that the internal phosphorus load could delay the response of the lake to decreases in external phosphorus loading. Internal loading represents only approximately 6 percent of the total phosphorus load of the lake. Therefore, the phosphorus trapped in the sediments should have minimal effect on long-term phosphorus concentrations and should not delay the response in the productivity of the lake to future decreases in nutrient loading from its watershed.

\section{References}

Anderson, W.L., Robertson, D.M., and Magnuson, J.J., 1996, Evidence of recent warming and El Nino-related variations in ice break up of Wisconsin Lakes: Limnology and Oceanography, v. 41, p. 815-821.

Ankley, G.T., Di Toro, D.M., Hansen, D.J., and Berry, W.J., 1996, Technical basis and proposal for deriving sediment quality criteria for metals: Environmental Toxicology and Chemistry, v. 15, p. 2056-2066.

Ayers and Associates, 2010, Mercer stormwater modeling and assessment: Eau Claire, Wis., 34 p.
Burkhardt, M.R., Zaugg, S.D., Smith, S.G., and ReVello, R.C., 2006, Determination of wastewater compounds in sediment and soil by pressurized solvent extraction, solid-phase extraction, and capillary-column gas chromatography/ mass spectrometry: U.S. Geological Survey Techniques and Methods, book 5, chap. B2, 33 p.

Canfield, D.E., and Bachmann, R.W., 1981, Prediction of total phosphorus concentrations, chlorophyll- $a$, and Secchi depths in natural and artificial lakes: Canadian Journal of Fisheries and Aquatic Sciences, v. 38, p. 414-423.

Carlson, R.E., 1977, A trophic state index for lakes: Limnology and Oceanography, v. 22, p. 361-369.

Cooke, G.D., Welch, E.B., Peterson, S.A., and Newroth, P.R., 1993, Restoration and management of lakes and reservoirs (2nd ed.), Boca Raton, Fla., Lewis Publishers, 548 p.

Correll, D.L., 1998, The role of phosphorus in the eutrophication of receiving waters-A review: Journal of Environmental Quality, v. 27, no. 2, p. 261-266.

Corsi, S.R., Graczyk, D.J., Owens, D.W., and Bannerman, R.T., 1997, Unit-area loads of suspended sediment, suspended solids and total phosphorus from small watersheds in Wisconsin: U.S. Geological Survey Fact Sheet 195-97, 4 p.

Doherty, John, 2010, PEST-Model-Independent Parameter Estimation, user manual (5th ed.): Brisbane, Australia, Watermark Numerical Computing, 336 p.

Dripps, W.R., Hunt, R.J., and Anderson, M.P., 2006, Estimating recharge rates with analytic element models and parameter estimation: Ground Water, v. 44, p. 47-55.

Edwards, T.K., and Glysson, G.D., 1999, Field methods for measurement of fluvial sediment: U.S. Geological Survey Techniques of Water-Resources Investigations, book 3, chap. C2, 89 p.

ePodunk, Inc., 2007, Oneida County, WI, profile-Population overview, accessed Dec. 12, 2011, at http://www.epodunk. com/cgi-bin/popInfo.php?locIndex $=23146$.

Farnsworth, R.K., and Thompson, E.S., 1982, Mean monthly, seasonal, and annual pan evaporation for the United States: National Oceanic and Atmospheric Administration Technical Report NWS 34, 82 p.

Fishman, M.J., and Friedman, L.C., 1989, Methods for determination of inorganic substances in water and fluvial sediments: U.S. Geological Survey Techniques of WaterResources Investigations, book 5, chap. A1, 545 p. 
Fishman, M.J., Raese, J.W., Gerlitz, C.N., and Husband, R.A., 1994, U.S. Geological Survey approved inorganic and organic methods for the analysis of water and fluvial sediment, 1954-94: U.S. Geological Survey Open-File Report 94-351, $55 \mathrm{p}$.

Fitzpatrick, F.A., and Peppler, M.C., 2003, Sedimentation and sediment chemistry, Neopit Mill Pond, Menominee Indian Reservation, Wisconsin, 2001: U.S. Geological Survey Open-File Report 03-23, 58 p.

Garbarino, J.R., and Struzeski, T.M., 1998, Methods of analysis by the U.S. Geological Survey National Water Quality Laboratory-Determination of elements in whole-water digests using inductively coupled plasma-optical emission spectrometry and inductively coupled plasma-mass spectrometry: U.S. Geological Survey Open-File Report 98-165, $101 \mathrm{p}$.

Garn, H.S., Olson, D.L., Seidel, T.L., and Rose, W.J., 1996, Hydrology and water quality of Lauderdale Lakes, Walworth County, Wisconsin, 1993-94: U.S. Geological Survey Water-Resources Investigations Report 96-4235, 29 p.

Garn, H., Robertson, D.M., Rose, W.J., and Saad, D.A., 2010, Hydrology, water quality, and response to simulated changes in phosphorus loading of Minocqua and Kawaguesaga Lakes, Oneida County, Wisconsin, with emphasis on effects of urbanization: U.S. Geological Survey Scientific Investigations Report 2010-5196, 54 p.

Garrison, P.J., 2005, Paleoecological study of Mercer and Grand Portage Lakes, Iron County, Wisconsin: Wisconsin Department of Natural Resources, Bureau of Integrated Science Services, PUB-SS-1013, 17 p.

Graczyk, D.J., Hunt, R.J., Greb, S.R., Buchwald, C.A., and Krohelski, J.T., 2003, Hydrology, nutrient concentrations, and nutrient yields in nearshore areas of four lakes in northern Wisconsin, 1999-2001: U.S. Geological Survey WaterResources Investigations Report 03-4144, 64 p.

Graneli, Wilhelm, 1999, Internal phosphorus loading in Lake Ringsjon: Hydrobiologia, v. 404, p. 19-26.

Haitjema, H.M., 1995, Analytic element modeling of groundwater flow: San Diego, Calif., Academic Press, 394 p.

Hem, J.D., 1985, Study and interpretation of the chemical characteristics of natural waters ( $3 \mathrm{~d}$ ed.): U.S. Geological Survey Water-Supply Paper 2254, 264 p.

Hole, F.D., Beatty, M.T., Milfred, C.J., Lee, G.B., and Klingelhoets, A.J., 1968, Soils of Wisconsin: University of Wisconsin-Extension, Wisconsin Geological and Natural History Survey, scale 1:710,000, 1 sheet.
Hunt, R.J., Anderson, M.P., and Kelson, V.A., 1998, Improving a complex finite-difference ground water flow model through the use of an analytic element screening model: Ground Water, v. 36, no. 6. p. 1011-1017.

James, W.F., and Barko, J.W., 1991, Littoral-pelagic phosphorus dynamics during nighttime convective circulation: Limnology and Oceanography, v. 36, p. 949-960.

James, W.F., and Barko, J.W., 2004, Diffusive fluxes and equilibrium processes in relation to phosphorus dynamics in the Upper Mississippi River: River Research and Applications, v. 20, p. $473-484$.

Juckem, P.F., and Hunt, R.J., 2007, Simulation of the shallow ground-water-flow system near Grindstone Creek and the Community of New Post, Sawyer County, Wisconsin: U.S. Geological Survey Scientific Investigations Report 2007-5014, 30 p.

Koltun, G.F., Eberle, C.M., Gray, J.R., and Glysson, G.D, 2006, User's manual for the Graphical Constituent Loading Analysis System (GCLAS): U.S. Geological Survey Techniques and Methods, book 4, chap. C1, $51 \mathrm{p}$.

Larsen, D.P., and Mercier, H.T., 1976, Phosphorus retention capacity of lakes: Journal of the Fisheries Research Board of Canada, v. 33, p. 1742-1750.

Larsen, D.P., Van Sickle, J., Malueg, K.W., and Smith, P.D., 1979, The effect of wastewater phosphorus removal on Shagawa Lake, Minnesota: Phosphorus supplies, lake phosphorus, and chlorophyll $a$ : Water Resources, v. 13, p. 1259-1272.

Larsen, D.P., Schults, D.W., and Malueg, K.W., 1981, Summer internal phosphorus supplies in Shagawa Lake, Minnesota: Limnology and Oceanography, v. 26, p. 740-753.

Lillie, R.A., and Mason, J.W., 1983, Limnological characteristics of Wisconsin lakes: Wisconsin Department of Natural Resources, Technical Bulletin 138, 116 p.

Mercer Lake Association, 2007, Preliminary lake watershed management plan for Mercer Lake, accessed Dec. 12, 2012, at http://dnr.wi.gov/lakes/grants/largereports/LPL-1063-06. $p d f$.

Mortimer, C.H., 1941. The exchange of dissolved substances between mud and water in lakes: Journal of Ecology, v. 29, p. $280-329$.

Mudrey, M.G., Jr., Brown, B.A., and Greenberg, J.K., 1982, Bedrock geologic map of Wisconsin: University of Wisconsin-Extension, Wisconsin Geological and Natural History Survey, scale 1:1,000,000, 1 sheet. 
Multi-Resolution Land Characteristics Consortium, 2001, 2001 National Land Cover Data (NCLD 2001): U.S Environmental Protection Agency, accessed Dec. 12, 2011, at http://www.epa.gov/mrlc/nlcd-2001.html.

National Climatic Data Center, 2007-09, Climatological data: Asheville, N.C., National Oceanic and Atmospheric Administration (published monthly).

Natural Resources Conservation Service, 2010, Web Soil Survey, accessed Dec. 12, 2011, at http://websoilsurvey.nrcs. usda.gov/app/.

Newton, B.J., and Jarrell, W.M., 1999, A procedure to estimate the response of aquatic systems to changes in phosphorus and nitrogen inputs: U.S. Department of Agriculture, National Water and Climate Center, NWCC-TN-99-2, $37 \mathrm{p}$.

Nurnberg, G.K., 1998, Prediction of annual and seasonal phosphorus concentrations in stratified and polymictic lakes: Oceanography and Limnology, v. 43, p. 1544-1552.

Oakes, E.L., and Cotter, R.D. 1975, Water resources of Wisconsin-Upper Wisconsin River Basin: U.S. Geological Survey Hydrologic Investigations Atlas HA-536, 3 sheets, scale 1:1,000,000.

Omernik, J.M., Chapman, S.S., Lillie, R.A., and Dumke, R.T., 2000, Ecoregions of Wisconsin: Transactions of the Wisconsin Academy of Sciences, Arts, and Letters, v. 88, p. $77-103$.

Osgood, R.A., 1988, Lake mixis and internal phosphorus dynamics: Archives of Hydrobiology v. 113, p. 629-638.

Osgood, R.A., Brezonik, P.L., and Hatch, L., 2002, Methods for classifying lakes based on measures of development impacts: University of Minnesota Water Resource Center, Technical Report 143, 32 p.

Outdoor Network, Inc., 2011, Mercer Wisconsin, accessed Nov. 18, 2011, at http://www.mercerwi.com/.

Panuska, J.C., and Kreider, J.C., 2003, Wisconsin lake modeling suite program documentation and user's manual, version 3.3 for Windows: Wisconsin Department of Natural Resources PUBL-WR-363-94, 32 p., accessed Dec. 12, 2011, at http://dnr.wi.gov/lakes/model/.

Pitt, R., and Voorhees, J., 1993, Source loading and management model (SLAMM) seminar publication, in Seminar publication, National Conference on Urban Runoff Management-Enhancing urban watershed management at the local, county, and state levels, March 30-April 2, 1993: Cincinnati, Ohio, U.S. Environmental Protection Agency Center for Environmental Research Information, EPA/625/R-95/003, p. 225-243.
Rantz, S.E., and others, 1982, Measurement and computation of streamflow-Volume 1, measurement of stage and discharge: U.S. Geological Survey Water-Supply Paper 2175, $284 \mathrm{p}$.

Reckhow, K.H., Beaulac, M.N., and Simpson, J.T., 1980, Modeling phosphorus loading in lake response under uncertainty-A manual and compilation of export coefficients: U.S. Environmental Protection Agency EPA-440/5-80-011.

Reckhow, K.H., and Chapra, S.C., 1983, Engineering approaches for lake management, volume I: Data analysis and empirical modeling: Boston, Butterworths Publishers, $340 \mathrm{p}$.

Robertson, D.M., Goddard, G.L., Mergener, E.A., Rose, W.J., and Garrison, P.J., 2002, Hydrology and water quality of Geneva Lake, Walworth County, Wisconsin, U.S. Geological Survey Water-Resources Investigations Report 02-4039, $73 \mathrm{p}$.

Robertson, D.M., and Rose, W.J., 2008, Water quality, hydrology, and simulated response to changes in phosphorus loading of Butternut Lake, Price and Ashland Counties, Wisconsin, with special emphasis on the effects of internal phosphorus loading in a polymictic lake: U.S. Geological Survey Scientific Investigations Report 2008-5053, 46 p.

Robertson, D.M., Rose, W.J., and Fitzpatrick, F.A., 2009, Water quality and hydrology of Silver Lake, Barron County, Wisconsin, with special emphasis on the responses of a terminal lake to changes in phosphorus loading and water level: U.S. Geological Survey Scientific Investigations Report 2009-5077, 38 p.

Robertson, D.M., Rose, W.J., and Juckem, P.F., 2009, Water quality and hydrology of Whitefish (Bardon) Lake, Douglas County, Wisconsin, with special emphasis on responses of an oligotrophic seepage lake to changes in phosphorus loading and water level: U.S. Geological Survey Scientific Investigations Report 2009-5089, 41 p.

Robertson, D.M., Rose, W.J., and Saad, D.A., 2005, Water quality, hydrology, and phosphorus loading to Little St. Germain Lake, Wisconsin, with special emphasis on the effects of winter aeration and ground-water inputs: U.S. Geological Survey Scientific Investigations Report 2005-5071, 36 p.

Shaw, Byron, Mechenich, Christine, and Klessig, Lowell, 1993, Understanding lake data: Madison, Wis., University of Wisconsin Extension Report G3582, 19 p.

Strack, O.D.L., 1989, Groundwater mechanics: Englewood Cliffs, N.J., Prentice Hall, 732 p. 
Thomas J.C., Lutz, M.A., Bruce, J.L., Graczyk, D.J., Richards, K.D., Krabbenhoft, D.P., Westenbroek, S.M., Scudder, B.C., Sullivan, D.J., Bell, A.H., 2007, Water-quality characteristics for selected sites within the Milwaukee Metropolitan Sewerage District planning area, Wisconsin, February 2004-September 2005: U. S. Geological Survey Scientific Investigations Report 2007-5084, 187 p.

Town of Mercer, 2011, Town of Mercer: Loon capital of the world: Accessed Nov. 22, 2011, at http://www.townofmercer. $\mathrm{com} /$.

Trotta, L.C., and Cotter, R.D., 1973, Depth to bedrock in Wisconsin: University of Wisconsin-Extension, Wisconsin Geological and Natural History Survey, Map, 1 pl.

U.S. Census Bureau, 2011, Census of population and housing, Wisconsin: U.S. Census Bureau database, accessed Dec. 12, 2011, at http://www.census.gov/prod/www/abs/decennial/ index.htm.

U.S. Department of Agriculture, 2006, National Agricultural Imagery Program (NAIP) digital orthorectified images (DOQ), Wisconsin: Accessed Dec. 12, 2011, at http://datagateway.nrcs.usda.gov/.

U.S. Environmental Protection Agency, 1988, Ambient waterquality criteria for chloride-1988: U.S. Environmental Protection Agency, Office of Water, EPA 440/5-88-001, 39 p.

U.S. Geological Survey, 2009-10, Water resources data for the United States, water year 2008 through 2009-Wisconsin data (published annually): Available at http://wdr.water. usgs.gov/.

Vollenweider, R.A., 1975, Input-output models with special reference to the phosphorus loading concept in limnology: Schweizerische Zeitschrift fur Hydrologie, v. 27, p. 53-84.
Welch, E.B., and Cooke, G.D., 1995, Internal phosphorus loading in shallow lakes: Importance and control: Lake and Reservoir Management, v. 11, p. 273-281.

Wetzel, R.G., 1983, Limnology (2nd ed.): Philadelphia, W.B. Saunders, $767 \mathrm{p}$.

Wickman, Sandy, and Herman, Laura, 2005, Wisconsin citizen lake monitoring training manual, Wisconsin Department of Natural Resources, Madison, Wis., PUB-SS-1009, 54 p.

Wisconsin Department of Natural Resources, 1970, Surface water resources of Iron County: Department of Natural Resources, Madison, Wis., 165 p.

Wisconsin Department of Natural Resources, 1992, Wisconsin water quality assessment-Report to Congress, 1992: Publ-WR254-92-REV, 220 p.

Wisconsin Department of Natural Resources, 2003, Consensus-based sediment quality guidelines, recommendations for use and application, interim guidance: Madison, Wis., Wisconsin Department of Natural Resources WT-732-2003, December 2003, 35 p.

Wisconsin Department of Natural Resources, 2008, Wisconsin Citizen Lake Monitoring Network: Accessed Dec. 12, 2011, at http://dnr.wi.gov/lakes/CLMN/.

Wisconsin State Laboratory of Hygiene, Environmental Sciences Section, 1993, Manual of analytical methods, inorganic chemistry unit: Madison, Wisconsin State Laboratory of Hygiene, revised November 1993 [variously paginated].

Young, H. L. and Hindall, S. M., 1972, Water Resources of Wisconsin-Chippewa River Basin: U. S. Geological Survey Hydrologic Investigations Atlas HA-386. 
Appendix 1. Wastewater indicators in sediment (Schedule 5433 compounds), analyzed at the U.S. Geological Survey National Water Quality Laboratory in Denver Colo.

[EDP, endocrine-disrupting potential; S, suspected; K, known; $\mu \mathrm{g} / \mathrm{kg}$, microgram per kilogram; >, greater than; CP, combustion product; PAH, polycyclic aromatic hydrocarbon; --, no data. Table adapted from J. R. Ward, U. S. Geological Survey, written commun., February 28, 2006]

\begin{tabular}{|c|c|c|c|}
\hline Compound name & $\begin{array}{l}\text { Reporting level, } \\
\mu \mathrm{g} / \mathrm{kg}\end{array}$ & EDP & Possible compound uses or sources \\
\hline 1,4-Dichlorobenzene & 50 & $\mathrm{~S}$ & Moth repellant, fumigant, deodorant. \\
\hline 1-Methylnaphthalene & 50 & - & 2-5 percent of gasoline, diesel fuel, or crude oil. \\
\hline 2,6-Dimethylnaphthalene & 50 & - & Present in diesel/kerosene (trace in gasoline). \\
\hline 2-Methylnaphthalene & 50 & - & 2-5 percent of gasoline, diesel fuel, or crude oil. \\
\hline 3-beta-Coprostanol & 500 & - & Carnivore fecal indicator. \\
\hline 3-Methyl-1H-indole (skatol) & 50 & - & Fragrance, stench in feces and coal tar. \\
\hline 3-tert-Butyl-4-hydroxy anisole (BHA) & 150 & $\mathrm{~K}$ & Antioxidant, general preservative. \\
\hline 4-Cumylphenol & 50 & $\mathrm{~K}$ & Nonionic detergent metabolite. \\
\hline 4-n-Octylphenol & 50 & $\mathrm{~K}$ & Nonionic detergent metabolite. \\
\hline 4-tert-Octylphenol & 50 & $\mathrm{~K}$ & Nonionic detergent metabolite. \\
\hline Acetophenone & 150 & - & Fragrance in detergent and tobacco, flavor in beverages. \\
\hline $\begin{array}{l}\text { Acetyl-hexamethyl-tetrahydro- naphthalene } \\
\text { (AHTN) }\end{array}$ & 50 & - & Musk fragrance (widespread use) persistent in groundwater. \\
\hline Anthracene & 50 & - & Wood preservative, component of tar, diesel, or crudeoil, CP. \\
\hline Anthraquinone & 50 & - & Manufacturing dye/textiles, seed treatment, bird repellant. \\
\hline Atrazine & 100 & - & Selective triazine herbicide. \\
\hline Benzo $[a]$ pyrene & 50 & $\mathrm{~K}$ & Regulated PAH, used in cancer research, CP. \\
\hline Benzophenone & 50 & $\mathrm{~S}$ & Fixative for perfumes and soaps. \\
\hline beta-Sitosterol & 500 & - & Plant sterol. \\
\hline beta-Stigmastanol & 500 & - & Plant sterol. \\
\hline Bisphenol A & 50 & $\mathrm{~K}$ & $\begin{array}{l}\text { Manufacturing polycarbonate resins, antioxidant, flame } \\
\text { retardant. }\end{array}$ \\
\hline Bromacil & 1700 & $\mathrm{~K}$ & Herbicide, $>80$ percent noncrop usage on grass/brush. \\
\hline Camphor & 50 & - & Flavor, odorant, ointments. \\
\hline Carbazole & 50 & - & Insecticide, Manufacturing dyes, explosives, and lubricants. \\
\hline Chlorpyrifos & 170 & $\mathrm{~K}$ & Insecticide, domestic pest and termite control. \\
\hline Cholesterol & 250 & - & Often a fecal indicator. \\
\hline Diazinon & 170 & $\mathrm{~K}$ & Insecticide, $>40$ percent nonagricultural usage, ants, flies. \\
\hline Diethyl phthalate & 100 & - & Plasticizer for polymers and resins. \\
\hline Bis (2-Ethylhexyl) phthalate & 250 & - & Plasticizer for polymers and resins, pesticides. \\
\hline d-Limonene & 50 & - & Fungicide, antimicrobial, antiviral, fragrance in aerosols. \\
\hline Fluoranthene & 50 & - & $\begin{array}{l}\text { Component of coal tar and asphalt (only traces in gasoline or } \\
\text { diesel fuel), CP. }\end{array}$ \\
\hline $\begin{array}{l}\text { Hexahydrohexamethyl-cyclopentabenzopyran } \\
\text { (HHCB) }\end{array}$ & 50 & - & Musk fragrance (widespread use) persistent in groundwater. \\
\hline Indole & 100 & - & Pesticide inert ingredient, fragrance in coffee. \\
\hline Isoborneol & 50 & - & Fragrance in perfumery, in disinfectants. \\
\hline Isophorone & 50 & - & Solvent for lacquer, plastic, oil, silicon, resin. \\
\hline Isopropylbenzene & 100 & - & Manuf phenol/acetone, fuels and paint thinner. \\
\hline Isoquinoline & 100 & - & Flavors and fragrances. \\
\hline Menthol & 50 & - & Cigarettes, cough drops, liniment, mouthwash. \\
\hline Metolachlor & 170 & - & Herbicide, indicator of agricultural drainage. \\
\hline
\end{tabular}


Appendix 1. Wastewater indicators in sediment (Schedule 5433 compounds), analyzed at the U.S. Geological Survey National Water Quality Laboratory in Denver Colo.-Continued

[EDP, endocrine-disrupting potential; S, suspected; K, known; $\mu \mathrm{g} / \mathrm{kg}$, microgram per kilogram; >, greater than; $\mathrm{CP}$, combustion product; PAH, polycyclic aromatic hydrocarbon; --, no data. Table adapted from J. R. Ward, U. S. Geological Survey, written commun., February 28, 2006]

\begin{tabular}{|c|c|c|c|}
\hline Compound name & $\begin{array}{l}\text { Reporting level, } \\
\mu \mathrm{g} / \mathrm{kg}\end{array}$ & EDP & Possible compound uses or sources \\
\hline N,N-Diethyl-meta-toluamide (Deet) & 100 & - & Insecticide, urban uses, mosquito repellent. \\
\hline Naphthalene & 50 & - & $\begin{array}{l}\text { Fumigant, moth repellent, major component } \\
\text { (about } 10 \text { percent) of gasoline. }\end{array}$ \\
\hline Nonylphenol diethoxylates & 1000 & $\mathrm{~K}$ & Nonionic detergent metabolite. \\
\hline 4-Nonylphenol & 750 & - & Nonionic detergent metabolite. \\
\hline Octylphenol diethoxylates & 50 & $\mathrm{~K}$ & Nonionic detergent metabolite. \\
\hline Octylphenol monoethoxylates & 250 & $\mathrm{~K}$ & Nonionic detergent metabolite. \\
\hline p-Cresol & 250 & $\mathrm{~S}$ & Wood preservative. \\
\hline para-Nonylphenol (total) & 500 & $\mathrm{~K}$ & Nonionic detergent metabolite. \\
\hline Phenanthrene & 50 & - & $\begin{array}{l}\text { Manufacturing explosives, component of tar, diesel fuel, or } \\
\text { crude oil, CP. }\end{array}$ \\
\hline Phenol & 50 & - & Disinfectant, manuf several products, leachate. \\
\hline Prometon & 170 & - & Herbicide (noncrop only). \\
\hline Pyrene & 50 & - & $\begin{array}{l}\text { Component of coal tar and asphalt (only traces ingasoline or } \\
\text { diesel fuel), CP. }\end{array}$ \\
\hline 2,2,4,4 -Tetrabromodiphenyl ether & 50 & - & Fire retardant. \\
\hline Tri(2-butoxyethyl) phosphate & 150 & - & Flame retardant. \\
\hline Tri(2-chloroethyl) phosphate & 100 & $\mathrm{~S}$ & Plasticizer, flame retardant. \\
\hline Tri(dichloroisopropyl) phosphate & 100 & S & Flame retardant. \\
\hline Tributyl phosphate & 50 & - & Antifoaming agent, flame retardant. \\
\hline Triclosan & 50 & S & $\begin{array}{l}\text { Disinfectant, antimicrobial (concern for acquired microbial } \\
\text { resistance). }\end{array}$ \\
\hline Triphenyl phosphate & 50 & - & Plasticizer, resin, wax, finish, roofing paper, flame retardant. \\
\hline
\end{tabular}


Publishing support provided by the U.S. Geological Survey Science Publishing Network, Columbus Publishing Service Center

For more information concerning the research in this report, contact the Director, Wisconsin Water Science Center

U.S. Geological Survey

8505 Research Way

Middleton, Wisconsin 53562

http://wi.water.usgs.gov/ 
